Essays on Angel Investing in the Entrepreneurial Ecosystem

Alessandro Piazza

Submitted in partial fulfillment of the requirements for the degree of Doctor of Philosophy under the Executive Committee of the Graduate School of Arts and Sciences

COLUMBIA UNIVERSITY 
(C) 2018

Alessandro Piazza

All rights reserved 


\title{
ABSTRACT \\ Essays on Angel Investing in the Entrepreneurial Ecosystem
}

\author{
Alessandro Piazza
}

Throughout its three chapters, this dissertation examines a phenomenon that, although underappreciated and underinvestigated in the existing literature, should be of great interest to entrepreneurship scholars: angel investing in the United States. While most of the existing studies of venture financing have predominantly focused on venture capital (VC) funding, angel investing - that is, wealthy individuals investing their own money in new ventures - represents almost as large of a market as venture capital, and recent empirical evidence suggests that ventures financed by angel investors tend to be more successful than comparable ventures that are not angelfinanced. More interestingly, perhaps, angel investing tends to focus on ventures at the earliest stage, which leads to investor making decisions based on very little hard evidence. This results in the attempt, on the investors' part, to reduce uncertainty by leveraging one's connections and community-level patterns of social relations. In this regard, this dissertation's main objective is to tackle the existing literature's "undersocialized" take on venture financing, and to show the sociological mechanisms that might underpin the decision by entrepreneurs to enter the angel investing market by becoming suppliers of capital, as well as their capital allocation choices, i.e. their investment decisions. Additionally, this work also examines the drivers of success for angel investors, with a view to explaining — at least in part—why certain individuals are wildly more successful than others at angel investing. Empirically, my work relies on a combination of archival data - primarily data gathered from online data source CrunchBase, but also U.S. Census data and 
hand-collected information from LinkedIn-and fieldwork in the form of interviews with entrepreneurs and angel investors, as well as participant observation at the Angel Capital Association Annual Meeting in San Francisco, the largest yearly gathering of angel investors. The resulting empirical patterns, both qualitative and quantitative, when taken in their entirety suggests that angel investing is a social process, and particularly that entrepreneurs are socialized into becoming angel investors by interacting with the angels who finance their ventures. Further, this work offers evidence that community-level patterns of socialization - i.e. what is generally known in sociology as community social capital—also plays a role in determining whether entrepreneurs will become angel investors and, once they choose to take this step, whether they will show a preference for financing local ventures vis-à-vis pursuing investment opportunities elsewhere. Finally, this work also addresses the question of angel investing outcomes- that is, why some angel investors are more successful than others, as measured by the number of exits in their investment portfolio. In this regard, empirical results suggest that generalists do better than specialists, and that angel investors with broad entrepreneurial experience are found to do especially well. Success is also a function of effective knowledge translation: on average, successful entrepreneurs tend to become more successful angels, and especially so the greater the overlap between the entrepreneurial experience of the founder and their angel investment portfolio. 


\section{TABLE OF CONTENTS}

List of tables

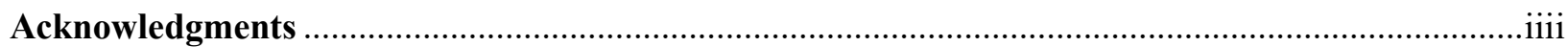

Preface

From Founders to Funders: Generalized Reciprocity and the Reproduction of Homophily in the

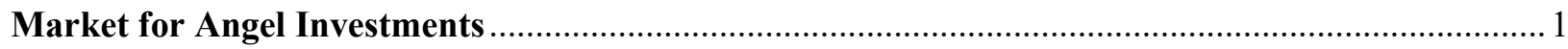

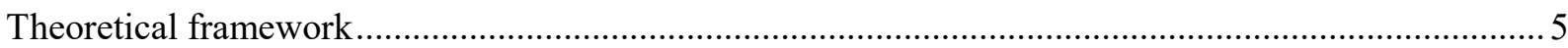

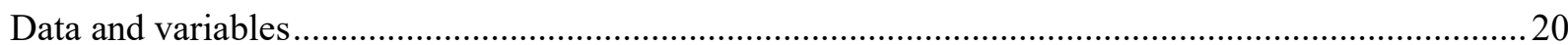

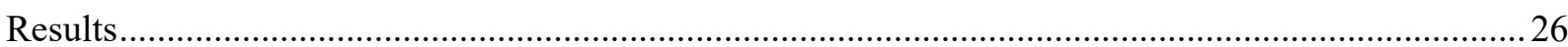

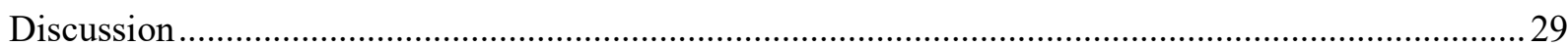

What Makes You Fly: Explaining Entrepreneurs' Success in Angel Investing ..............................43

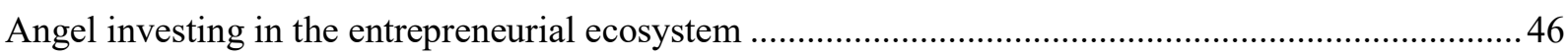

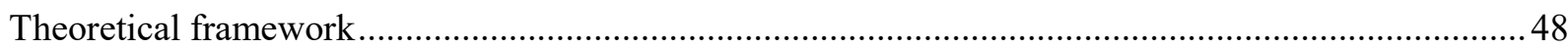

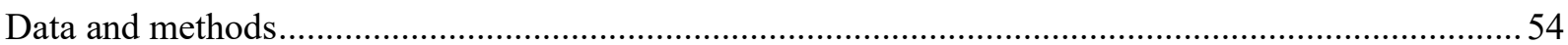

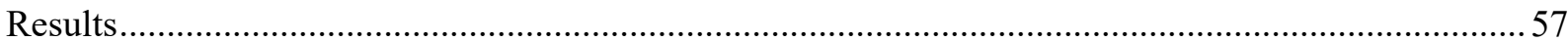

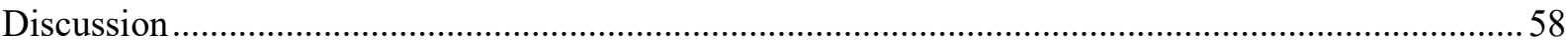

Community Social Capital and the Financing of New Ventures: Evidence from Angel Investing,

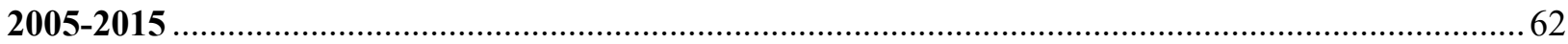

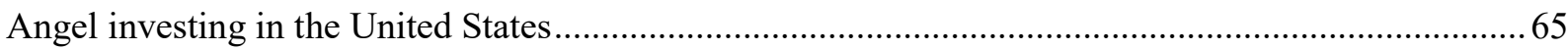

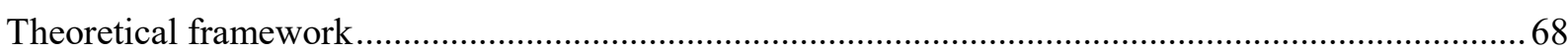

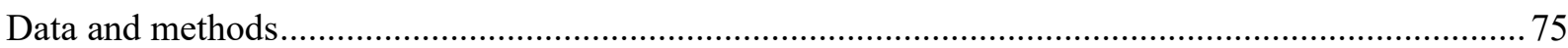

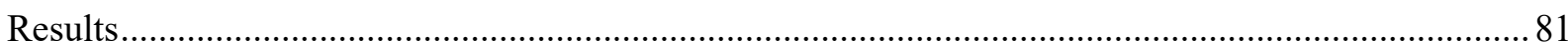

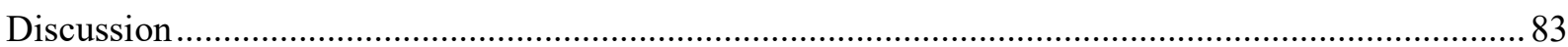

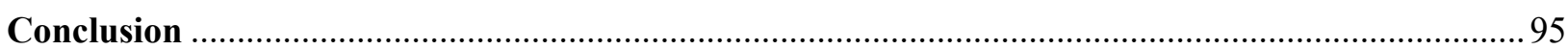

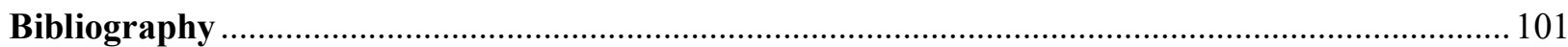




\section{LIST OF TABLES}

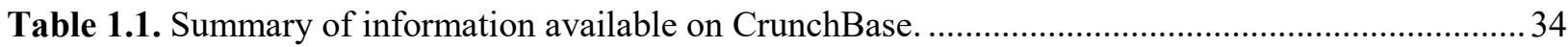

Table 1.2. Descriptive statistics and bivariate correlations for the first part of the study......................35

Table 1.3. Descriptive statistics and bivariate correlations for the second part of the study.....................36

Table 1.4. Results for Cox proportional hazards event-history models for the hazard of transitioning..... 37

Table 1.5. Results for Cox proportional hazards event-history models for the hazard of transitioning to

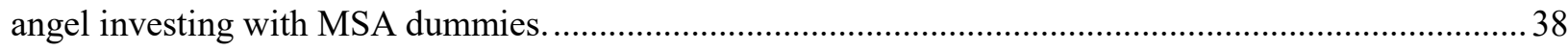

Table 1.6. Panel negative binomial results for investments made towards founders of the same gender as the angel investor.

Table 1.7. Panel negative binomial results for investments made towards founders having a school tie with the angel investor.

Table 1.8. Panel negative binomial results for investments made towards founders located within the same MSA as the angel investor.

Table 1.9. Panel negative binomial results for investments made under the three homophily conditions, with MSA dummies.

Table 2.1. Descriptive statistics and correlation table. 60

Table 2.2. Panel OLS models for the number of successful exits in the focal angel investors portfolio...61

Table 3.1. Descriptive statistics and correlation table for all study variables. 88

Table 3.2. Fixed-effects panel OLS models for the logged number of VC-backed entrepreneurs within the MSA.

Table 3.3. Fixed-effects panel OLS models for the logged number of VC-backed entrepreneurs-turnedangels within the MSA.

Table 3.4. Fixed-effects panel OLS models for the logged number of angel investments made by angels in the MSA towards companies in the same MSA.

Table 3.5. Fixed-effects panel OLS models for the ratio of angel investments made by angels in the MSA towards companies in the same MSA to the total number of angel investments made by individuals in the MSA. 


\section{ACKNOWLEDGMENTS}

Getting a Ph.D. is arguably much less about obtaining a diploma than it is about the journey required to get there. Ever since I was very young, I have always thought of my education as an intellectual process of self-discovery, first and foremost. And now that the journey appears to finally be at an end, I came to realize that there is more knowledge out there than I will ever be able to acquire - even in my field alone — and, in a sense, the further I go along this path the more I am simply plumbing the depths of my own ignorance. Luckily for me, it looks like academia will also become my career for the foreseeable future, and so in a way the journey and the exploration will continue. Onwards and upwards!

It goes without saying that I would never have made it this far without the constant, unwavering support I have received from a variety of sources. While I can only hope to be comprehensive in acknowledging and thanking them, I do hope any oversight on my part in this matter will be forgiven. First of all, I owe a great debt of gratitude to my committee members. My advisor, Damon Phillips, who has provided wise guidance, both personal and professional, for the past five years, showing infinite patience towards my many side projects and various intellectual detours; without him, this dissertation might have never been completed. My committee chair, Paul Ingram, who- like me - is very much the intellectual wanderer and who taught me most of what I know about good teaching during the three years I spent shadowing him in the classroom. Dan Wang, who joined Columbia at the same time I did and who has been a constant presence in my research activities ever since, always leading by example. Mabel Abraham, an exceptional early-career scholar whom I am very lucky to have on board. And David Stark, who taught the 
first ever graduate-level seminar in economic sociology I took at Columbia, which had an outsized influence on the way I came to think about problems.

My colleagues and coauthors who have graced my years in academia also deserve special mention. Fabrizio Perretti, who was my main mentor during my Milan years and who later turned into one of my most reliable, trusted, and intellectually stimulating coauthors I have ever had the pleasure of working with. Julien Jourdan, for agreeing to walk the fascinating path of research on stigma and scandals with me, and for having done so ever since. Fabrizio Castellucci, with whom I wrote my very first paper and has remained a close colleague and confidante ever since. Eric Abrahamson, for his brilliance and his kind soul, as well as for having shown by example that a certain lack of discipline and systematicity does not always get in the way of becoming a good scholar but can instead spark creative chaos-a lesson which I have treasured. Grace Augustine, for exploring uncharted industries with me and for being a great friend all-around. These past few years, I have also enjoyed working with Barbara Slavich, Antonio Giangreco, Guy Holburn, and Adam Fremeth, among others, and I certainly hope our collaborations will continue. A special thank you should go to Ivana Katic: although we were never coauthors, her mentorship during my first few years at Columbia was invaluable. I would also like to express my appreciation for everyone at the Kauffman Foundation, for believing in me and my work enough to make me a Dissertation Fellow and for providing me with financial support, which enabled a more extensive data collection than would otherwise have been possible. Additional financial support was provided by the Lang Center at Columbia Business School and by the Werner L. and Adriana Chilton Doctoral Fellowship, of which I am also a proud recipient.

Having been in higher education for almost fifteen years now, I feel it is also important that I acknowledge all the people and all the institutions that have, in one way or another, made 
me who I am today, on a personal as well as a professional level. The University of Bologna and the Collegio Superiore, which I attended during my undergraduate years, for providing me with a full scholarship that eased the burden of my education on my family's finances, and for the lifelong gift of a world-class, interdisciplinary, public education I will always be proud of. The University of California, Berkeley, which graciously hosted me for research in Nuclear Engineering over a decade ago, and where I first learned about the many intricacies of U.S. higher education. The Collège des Ingénieurs in Paris, France, and SAFM, in Turin, Italy, for helping me take the first step towards getting a business education. Bocconi University, in Milan, for believing that a renegade nuclear engineer could one day become a decent management scholar, and for the intense, three-year period that helped me become one. And naturally Columbia University, for having been my school, employer, landlord, and background to my life for the past five years.

A final shout-out goes to my parents, who ultimately made all of this possible. I am absolutely convinced that I would never made it this far — in academia as well as in life — had it not been for them always going above and beyond for me. It is with immense gratitude that I dedicate this work to them.

New York, NY, March $10^{\text {th, }} 2018$ 


\section{PREFACE}

This dissertation comprises three chapters, which are tied together by their common focus on angel investing, as well as by a common data collection process. Taken together, the three chapters explore: a) entry into angel investing by entrepreneurs, which I often refer to as the transition between entrepreneurship and angel investing; b) investment decisions by entrepreneurs-turnedangels; c) angel investing outcomes and their antecedents. Empirically, the dissertation's cornerstone is CrunchBase, a crowdsourced online database which reports information on entrepreneurs, investors, funds, and new ventures, as well as on incubators and accelerators. This information is then supplemented with hand-collected LinkedIn information on each of the individuals - angels and entrepreneurs - in the sample, which allowed me to collect fine-grained information on location, career history and education. To refine my knowledge of the empirical setting and to gain relevant domain knowledge, I also collected qualitative data in the form of interviews with angel investors and entrepreneurs, as well as participant observation at angel group meetings and the Angel Capital Association annual meeting in San Francisco.

In Chapter I, I examine the question of entry into angel investing by entrepreneurs. While a majority of US-based angel investors are former entrepreneurs, what drives this career transition is not clear, especially given angel investing's average returns, which tend to be lower than venture capital in spite of angel investing being much riskier. Moreover, as far as theory is concerned, the social processes that govern entry into venture financing markets have received little scholarly attention, despite their importance for entrepreneurship. I make two sociologically-driven arguments: first, that entrepreneurs should be more likely to become angel investors when they have received angel funding themselves in the past, due to generalized reciprocity. Further, I argue that this effect should be stronger under conditions of homophily-i.e. when entrepreneurs and the 
angels financing them are similar across one or more dimensions. Finally, the homophily patterns in venture financing I just described should be reproduced as entrepreneurs become angel investors and make their own funding decisions. My empirical results provide support for these arguments.

Chapter II, which is joint work with Dan J. Wang, examines the antecedents of successful angel investing outcomes by entrepreneurs. Prevailing wisdom in the ecosystem holds that entrepreneurs are uniquely positioned to do well as investors, in that they possess tacit knowledge not just about their industry, but about the working mechanisms of venture financing, as well. Leveraging a sample of U.S. angel investors with entrepreneurial experience drawn from CrunchBase and linking their investment performance to their track record as entrepreneurs, show that while investing across market categories is associated with a higher number of successful exits in general, angel investors with broad entrepreneurial experience are found to do especially well. Success is also a function of effective knowledge translation: on average, successful entrepreneurs tend to become more successful angels, but we find this effect to be stronger the greater the overlap between the entrepreneurial experience of the founder and their angel investment portfolio.

The third and final chapter, Chapter III, looks into the role played by social capital in the emergence of entrepreneurial ecosystem, once again with particular reference to angel investing. A useful starting point, here, is the growing scholarly recognition of the fact that entrepreneurial ecosystem dynamics are a function, at least in part, of the characteristics the social milieu in which they are embedded. Venture financing, in particular, can be seen a social process, insofar as it requires the development of relationships between one of more investors and the founding team. If this is the case, then community-level characteristics that catalyze and encourage social interaction could have a positive effect on the ecosystem. I therefore advance the argument that social capital could have a bearing on individual decision concerning entry into venture financing, 
as well as capital allocation choices. This is because both the decision to become an entrepreneur and the eventual, subsequent transition to angel investing are inherently social, and are therefore especially likely to occur in communities that are characterized by greater social connectedness. Furthermore, areas with more well-developed opportunity structures for socialization should also be especially conducive to the development of local financing relationships. In this study, I thus examine the role of community social capital in angel investing across Metropolitan Statistical Areas (MSAs) in the United States between 2005 and 2015. In so doing, I show that: 1) MSAs with greater social capital exhibit a higher density of VC-funded entrepreneurs; 2) in such MSAs, a greater proportion of this population of entrepreneurs will become angel investors; and 3) such areas are also characterized by a comparatively higher proportion of angel investments targeting companies within the same MSA. I then discuss the implications of my findings for the literature on community social capital in sociology, as well as for the broader scholarly understanding of entrepreneurial ecosystems.

Collectively, the three chapters the dissertation comprises represent my attempt to provide a comprehensive account of the phenomenon of angel investing in the United States. While this topic has received some attention in the literature (e.g. Shane, 2008; Van Osnabrugge \& Robinson, 2000), I believe that beyond its importance for entrepreneurship, the informal supply of capital phenomenon that angel investors exemplify should broadly be of interest to organizational scholars and economic sociologists alike, in that it configures an interesting empirical puzzle in a number of major ways. First, as I discuss at length in Chapter I, angel investing is time consuming while not being especially profitable. As far as capital allocation decisions go, it is therefore quite surprising to see it bloom into a market worth more than $\$ 20$ billion in the U.S. alone, given the widespread availability of less time consuming alternatives with equal (or better) profitability. 
Second, angel investing is uniquely challenging for investors because of the objective lack of information they face in most circumstances. Because angel investors typically invest at the earliest stage and, in most cases, pre-revenue, not much is known about the objective value of the entrepreneurial idea or about the founding team's ability to implement it and execute it. As a result, angel investors routinely engage in a variety of uncertainty reduction strategies, such as seeking referrals from trusted connections and relying on specific heuristics (Huang \& Pearce, 2015). The informal supply of capital can thus be configured as being governed predominantly by social dynamics, which should make it an interesting empirical setting for scholars across disciplines. Third, the very emergence of a market for the informal supply of capital should in itself be surprising, since informal lending patterns have historically been associated with the lack—or the ineffectiveness — of formal institutions dedicated to this purposes, such as in the case of microfinance (e.g. Canales \& Greenberg, 2016). It is then especially noteworthy, then, to see how the communities with higher social capital actually show more angel investing, and not less, as shown in Chapter III.

Overall, my research begins to address all of these puzzles by leveraging a variety of literatures ranging from organizational perspectives on learning (Levitt \& March, 1988; March, Sproull, \& Tamuz, 1991), specialization (Åstebro \& Thompson, 2011; Lazear, 2004), and the role of expertise to sociological topics like homophily (McPherson, Smith-Lovin, \& Cook, 2001) generalized reciprocity (Yamagishi, Nobuhito, \& Kiyonari, 1999), and social capital (Coleman, 1988; Putnam, 1993). While the supply of capital has been extensively investigated by scholars in economics and finance for decades, it is my belief that economic sociology and organizational theory have much to offer when it comes to understanding this crucial component of the 
entrepreneurial ecosystem, and I hope that my research will pave the way for further work in this area. 


\title{
CHAPTER I
}

\section{From Founders to Funders: Generalized Reciprocity and the Reproduction of Homophily in the Market for Angel Investments}

\begin{abstract}
The literature on embeddedness has emphasized how economic transactions are framed by social relations, highlighting the interaction of social and economic factors in shaping the behavior of individuals and organizations in market settings. When it comes to investor participation in capital markets, however, the social processes that govern entry into such markets have received little scholarly attention, despite their importance for entrepreneurship. In this paper, I address the above issues within the context of entrepreneurial finance by examining the decision by entrepreneurs to become angel investors. In so doing, I leverage a novel dataset that combines biographical and career information about entrepreneurs with data on their investment patterns and the companies they founded. Building on the sociology literature, I show that generalized reciprocity is predictive of the transition to angel investing, in that entrepreneurs are more likely to become angel investors when they have received angel funding themselves in the past. I also find this effect to be stronger under conditions of homophily-i.e. when entrepreneurs and the angels financing them are similar across one or more dimensions. Finally, I show that homophily patterns in venture financing are reproduced as entrepreneurs become angel investors and make their own funding decisions. I conclude by discussing the contributions of my work to the sociology of markets, as well to the scholarly understanding of the dynamics of entrepreneurial ecosystems.
\end{abstract}

This research was funded in part by the Ewing Marion Kauffman Foundation. The contents of this publication are solely the responsibility of the author.

Keywords: angel investors; entrepreneurship; embeddedness; homophily; generalized reciprocity 
A topic of perennial interest within the sociology of financial markets concerns the process through which markets are populated - that is, how social actors decide to enter markets to seek exchange relationships. But while economic sociology and organizational theory have examined processes of entry by consumers of capital—such as organizations entering the stock market through IPOs (e.g. Pollock \& Rindova, 2003; Pollock, Rindova, \& Maggitti, 2008)—as well as their social antecedents (Rao, Davis, \& Ward, 2000), our disciplines have had relatively less to say about suppliers of capital, i.e. the individuals and organizations who enter markets in search of investment opportunities. This is likely because the decision to invest in a financial market is, under most circumstances, implicitly assumed to be motivated by profit maximization. Indeed, the neoclassical theory of investment behavior (e.g. Jorgenson, 1963), which postulates that the main goal of the investor is to optimize capital accumulation, seems to have remained largely dominant when it comes to explaining investor motives.

Beginning with Polanyi (1968) and Granovetter (1985), however, theories of market functioning have increasingly acknowledged that economic transactions are inextricable from the web of social relations in which they are embedded. At the same time, thanks to the growing influence of bounded rationality (Simon, 1957, 1991) and prospect theory (Kahneman \& Tversky, 1979), scholars have also come to recognize that market actors often operate in ways that transcend simple rationality and economic self-interest. We can therefore reasonably expect entry by suppliers of capital to be influenced by social ties - and indeed, the finance literature provides some early evidence that this is the case, in that stock market participation has consistently been found to be a function of social influence (Brown, Ivković, Smith, \& Weisbenner, 2008; Hong, Kubik, \& Stein, 2004; Kaustia \& Knüpfer, 2012). In a similar fashion, just like consumers of capital (e.g. entrepreneurs) are often motivated by non-monetary factors that go beyond profit 
maximization (Battilana \& Lee, 2014), we should expect investors not to be uniquely motivated by capital accumulation; the recent emergence of impact investing-i.e. investments meant to generate social or environmental impact alongside financial returns - suggests that this is likely the case. In this paper, therefore, I aim to contribute to the body of knowledge on the social antecedents of market participation by suppliers of capital, as well as to explore the latter's effect on the overall functioning of markets. More specifically, I ask: what social mechanisms affect the decision to enter capital markets and become an investor? And how do such processes impact the structure of markets as a whole? I examine these questions within the context of venture financing, and more specifically by looking into the participation of entrepreneurs in the market for angel investments.

Within entrepreneurial ecosystems, angel investing has come to play a prominent role in the process of venture financing, bridging the gap between early "friends-and-family" rounds and later rounds dominated by venture capital. Recent empirical findings suggest that angel-funded ventures experience superior outcomes compared to those that are not (Kerr, Lerner, \& Schoar, 2014), because angel investors provide mentorship and access to expertise and resources that go beyond capital (Huang \& Knight, 2017). Yet the motives for participating in the angel investment market pose an interesting empirical puzzle. On one hand, many of the most prolific and successful angel investors are former entrepreneurs. Indeed, a quantitative analysis by market intelligence platform CB Insights revealed that, among the top 20 most influential angel investors based on network centrality, more than three quarters are current or former entrepreneurs-including popular figures within the field like Max Levchin (PayPal), Marc Benioff (Salesforce), Aaron Levie (Box), Jerry Yang (Yahoo!), and Richard Branson (Virgin). ${ }^{1}$ Overall, estimates suggest that

\footnotetext{
${ }^{1}$ https://www.cbinsights.com/blog/top-angel-investors/
} 
between 60 and 90 percent of angel investors have entrepreneurial experience (Shane, 2008). Because the process of venture financing requires both socialization and tacit knowledge, it is certainly no wonder that former entrepreneurs are uniquely positioned to become angel investors. At the same time, such levels of participation are puzzling when one considers the evidence that angel investing is often relatively unrewarding from a financial standpoint, while requiring high levels of personal involvement; indeed, a majority of angel investments earning negative returns (Huang \& Pearce, 2015) and overall returns lower than those offered by venture capital in most cases. ${ }^{2}$ This begs the question of why certain entrepreneurs decide to take up angel investing, and what the mechanisms behind this transition might be.

In what follows, I leverage well-established constructs drawn from sociology to theorize about the process through which entrepreneurs become angel investors. In so doing, I advance the idea that the transition to angel investing is at least partly driven by social mechanisms, and that long-standing concepts such as generalized reciprocity (Tsvetkova \& Macy, 2014; Yamagishi \& Cook, 1993) and homophily (McPherson et al., 2001) can be appropriate choices to model it. Further, I show how these processes might have consequences going beyond the individual that receives funding, which in turn perpetuates existing funding arrangements and, by extension, the structure of the market. I begin by reviewing extant work on the social determinants of venture financing, with particular reference to high-tech entrepreneurship. I then introduce the empirical setting and I discuss each of the above ideas in detail, laying out specific hypotheses to be tested and my proposed contributions to practice. Finally, I discuss the specifics of my data, which blend qualitative information from fieldwork and interviews with quantitative data from archival sources; I present my results, and elaborate on the proposed contributions of my work to both the

\footnotetext{
${ }^{2}$ http://www.nber.org/digest/may01/w8066.html
} 
literature on angel investing and the scholarly understanding of the social antecedents of venture financing.

\section{THEORETICAL FRAMEWORK}

The problem of market participation. While organizational theory and economic sociology have been traditionally concerned with the antecedents of market entry by organizations (Haveman, 1993; Jensen, 2003), including participation in capital markets (e.g. Rao et al., 2000), the question of why individuals decide to participate in markets has received comparatively less attention (although see Yenkey, 2017). This is surprising, especially in light of economic sociology's long-standing interest in the social underpinnings of financial markets (Carruthers \& Kim, 2011). The finance literature, however, has made strides in this regard, providing convincing evidence that — far from being an entirely economic decision — market participation by individuals is crucially shaped by social factors, especially for what concerns the decision to become stockholders. For instance, Kaustia \& Knüpfer (2012) note that peer performance predict stock market entry, in that individuals are more likely to participate and buy stocks if local peers have done well in the stock market. Similarly, Hong et al. (2004) argue that social interaction is also a predictor of market participation, as individuals are more likely to buy stocks when they are more socially connected to their peers, and when the latter have higher rates of participation in the stock market. While not as prevalent within society as stock market participation, entrepreneurial finance provides a useful opportunity to explore the social antecedents of the decision to become an investor: in fact, stock market participation is largely faceless and transactional, and there is little

or no personal involvement on the investor's part. On the other hand, venture financing - and especially angel investing - often requires a personal connection between entrepreneurs and 
investors, which should make the process more susceptible to social influence and other interpersonal dynamics.

Social dynamics in venture financing. Up to this point, the organizational theory, management, and entrepreneurship literatures have extensively looked into the role that social connections play in the founding, development, and success of new ventures (Sorenson \& Stuart, 2001, 2008a; Stuart \& Sorenson, 2005). Such connections are thought to be important because they favor opportunity identification (Kacperczyk, 2013; Renzulli, Aldrich, \& Moody, 2000), they can aid entrepreneurs in mobilizing resources like financial capital and skilled labor (Hsu, 2004; Shane \& Stuart, 2002; Sorenson \& Stuart, 2001), and they can favor knowledge circulation (Sorenson \& Audia, 2000). In all, extant studies have advanced the view of entrepreneurship as a social process, with the decision to become an entrepreneur being conceptualized as partly a function of social influence (Kacperczyk, 2013); for instance, socializing with colleagues that have entrepreneurial experience in a workplace setting has been found to favor the transition to entrepreneurship (Nanda \& Sørensen, 2010). Entrepreneurs are also likely to base their founding choices on their extended social network, e.g. by choosing the location of their ventures based on where their family and friends live (Dahl \& Sorenson, 2010).

For what concerns venture financing more specifically, it has long been acknowledged that social considerations explain a substantial share of the variance in partnership decisions: for instance, investors who share ethnic, educational or career background are more likely to form syndicates (Gompers, Mukharlyamov, \& Xuah, 2016). ${ }^{3}$ Most of the extant studies on the social antecedents of venture financing, however, have focused on either investment performance or the decision to co-invest as dependent variables. As an example, Hochberg, Ljungqvist, \& Lu (2007)

\footnotetext{
${ }^{3}$ Interestingly enough though, Gompers et al. (2016) also find that investments made under conditions of homophily - i.e. in partnership with similar others - tend to earn comparatively lower profits.
} 
provide evidence that venture capital firms with more extensive networks of contacts are more likely to experience better fund performance, while Hegde \& Tumlinson (2014) find that ethnic proximity between VCs and the start-ups they invest in is positively related to the probability of a successful exit. Pre-founding social ties to established actor in the field were also associated with a higher success for entrepreneurial ventures (Roberts \& Sterling, 2012). In a similar fashion, Ter Wal, Alexy, Block, \& Sandner (2016) examine the effect of investors' social capital on the success of their portfolio ventures, finding that syndicates with open-specialized or closed-diverse networks are more likely to do well (see also Westlund \& Bolton, 2003 for the role of social capital in entrepreneurship). Social proximity is also found to be relevant: in a study of the U.S. venture capital industry, Hegde \& Tumlinson (2014) find that not only are VCs more likely to select coethnic investment partners, but that ethnic proximity between VCs and the startups they invest in is positively related to the probability of success (defined as exit via acquisition or IPO).

It must also be noted, however, that the majority of the existing studies to date have largely focused on venture capital, while neglecting less formalized funding arrangements such as those prevalent in early-stage financing. This is almost certainly a byproduct of data availability (or the lack thereof), as detailed funding information is readily available for venture capital from commercial databases such as VentureSource and VentureXpert, while angel and friends-andfamily investments are typically not reported, as they are not subjected to regulatory disclosure requirements. While former entrepreneurs are also quite prevalent among venture capitalists, they make up an even higher share of angel investors; this is because many venture capitalists have an investment banking background, rather than entrepreneurship background-which is comparatively less common among angel investors. By looking at the transition from entrepreneurship to angel investing, therefore, I intend to overcome the relatively narrow focus of 
the extant literature on just two dependent variables - performance and syndicate formationwhile at the same time devoting empirical attention to angel investing, a phenomenon that is both underinvestigated (to date) and increasingly consequential for entrepreneurial outcomes (Kerr et al., 2014). In the next section, therefore, I discuss the features of angel investing in the United States as an empirical setting.

Angel investing in the United States. Angel investing has grown in importance and visibility in the past decade, both in the United States and in other nations, developed and developing alike (Lerner, Schoar, Sokolinski, \& Wilson, 2016). While the size of the angel market is difficult to estimate due to the lack of official figures, in the United States it was believed to be as big as the venture capital market in 2004: indeed, based on official figures business angels invested \$23 billion in young companies, while venture capitalists invested about \$20 billion. In 2014, after the global financial crisis, the total U.S. angel market was estimated to be worth $\$ 24.1$ billion. In the past few years, angel investing has shown strong growth trends all over the world, with the European angel market doubling in size and the Canadian one tripling. ${ }^{4}$

According to Shane (2008: 14), "an angel investor is a person who provides capital, in the form of debt or equity, from his own funds to a private business owned and operated by someone else, who is neither a friend nor a family member". In this regard, angel investors differ from venture capitalists, who typically do not invest their own money, and from friends-and-family investors, who provide capital to business run by family or other acquaintances. Contrary to popular beliefs, not all angel investors in the United States are located in Silicon Valley or in New York; while there is undoubtedly a degree of concentration around these two main metropolitan

\footnotetext{
${ }^{4}$ http://www.kauffman.org/blogs/policy-dialogue/2016/march/the-rise-of-angel-investing
} 
areas, angel investors can be found all over the country, and many of them invest locally. ${ }^{5}$ Many angel investors are also not "wealthy" in the conventional sense: based on 2004 data from the Entrepreneurship in the United States Assessment, the majority of angel investors (66.7 percent) fail to meet the \$1 million minimum net worth required for SEC accreditation, and while 16.7 percent have a net worth over $\$ 2$ million, just as many angel investors apparently have a negative net worth. While most angel investors—-have discussed—have entrepreneurial experience, with 88 percent of them having started at least a company, they typically do not have more entrepreneurial experience than other informal investors; furthermore, most angel investors tend to be inexperienced investors. Finally, while most angel investors are white men, ethnic minorities tend to be overrepresented in angel investing relative to the general population, and women are just as likely as men to be business angels once other variables are accounted for. In all, the picture of angel investing in the United States does not fit the usual stereotype of the Silicon Valley millionaire leveraging his or her extensive entrepreneurial experience; rather, it is quite vibrant and diverse.

Why do angel investors decide to provide funding to entrepreneurs and their nascent ventures? Conventional wisdom suggests that the economic motive is the dominant force; that is, most angel investors decide to fund nascent ventures primarily to make money. In a survey of 230 business angels in Germany, Stedler \& Peters (2003) find support for this assertion, in that the desire to earn money and achieve superior returns was generally listed among the top four reasons for investing. It is not clear, however, whether angel investing is an effective way to achieve this vis-à-vis other types of investments. Indeed, recent evidence suggests that the returns to angel investing are "all but heavenly", with about half of all angel investments losing money and 48\%

\footnotetext{
${ }^{5}$ Source: 2008 ACA Angel Group Confidence Survey (http://tinyurl.com/j8kymlw)
} 
of investments resulting in a $100 \%$ loss. ${ }^{6}$ An empirical analysis of risk-adjusted returns on investment (ROI) as a function of funding stage ${ }^{7}$ reveals that there is an inverted U-shape relationship between funding stage and risk-adjusted returns, so that returns are highest in Series A and B but lowest at earlier and later stages of funding. Because an overwhelming majority of angel investments occur at the seed stage, it is therefore reasonable to assume that they are on average less profitable than other forms of investments in new ventures. Moreover, the vast majority of the profits from angel investing appear to be concentrated at the top, in the hands of well-connected veterans of high-growth industries. On the other hand, angels with less capital to offer and weaker links to expert advice are not especially likely to see high returns. This begs the question of why entrepreneurs might choose to pursue angel investing over other, possibly more lucrative opportunities. Otherwise stated, while the profit motive is certainly compelling, given the overwhelming odds of failure faced by most angel investors it stands to reason that it might be at best a partial explanation, and that other motivations of a different nature might come into play, too. In the following sections, therefore, I explore possible social antecedents of entrepreneurs' decision to pursue angel investing, drawing on well-established constructs from the sociology literature.

\section{Generalized exchange in angel investing.}

"In the order of nature we cannot render benefits to those from whom we receive them, or only seldom. But the benefit we receive must be rendered again, line for line, deed for deed, cent for cent, to somebody."

—Ralph Waldo Emerson

\footnotetext{
${ }^{6} \mathrm{http}: / / \mathrm{www} . w s j . c o m / a r t i c l e s / \mathrm{SB} 125694047773419513$

7 https://medium.com/@DunRobinVentures/evaluating-the-risk-reward-relationship-across-funding-rounds$\underline{\text { 5c951f21236b\#.fvij6po3v }}$
} 
If angel investing does not earn much money ${ }^{8}$ - and according to some, it is no better than gambling — - then why do entrepreneurs do it? Huang \& Pearce (2015) suggest that the decision to invest is often based on intuitive-emotional reasoning, with social cues being a substantive component. Many angel investors enjoy the interpersonal component of what they do- as opposed to relatively transactional, arm's length form of investments such as the stock marketas exemplified by the following quote by an angel investor:

"There are other areas where it might be easier or more lucrative to make good investments, like real estate or the stock market [...] But I think what makes a difference here is the human component. [...] It's that human element that really makes it more interesting for everybody. How can I help this human being leverage what they've done and create something new?"

These arguments are also reflected in the existing literature on the topic. In his discussion of angel investment patterns in the United States, Shane (2008) lists a variety of reasons: while some — such as making money or learning new things — can be seen as self-interested, others, like helping a friend or supporting their communities, are remarkably prosocial. Indeed, these prosocial reasons often trump economic motives. In the words of a professional investor:

In case you're interested, I make one or two angel investments each year, but I don't do it to make money. [...] I make those few angel investments because I want to help my best students achieve their goals, and because I like being involved in startups. That's the ultimate lesson from the fish stories in Silicon Valley. True fishermen cast their lines not because they want the fish, but because they like fishing. It's fine to be an angel investor - just don't do it for the money. ${ }^{10}$

\footnotetext{
${ }^{8}$ https://techcrunch.com/2012/10/13/angel-investors-make-2-5x-returns-overall/

${ }^{9}$ http://www.forbes.com/sites/dileeprao/2014/02/10/whats-riskier-angel-investing-or-gambling-invegas/\#9601403e3b35

${ }^{10}$ https://techcrunch.com/2012/09/30/why-angel-investors-dont-make-money-and-advice-for-people-who-aregoing-to-become-angels-anyway/
} 
This passage highlights how, for many angel investors, at the heart of their business lies the "desire to give something back to a place that has supported them in some way" (Shane, 2008: 23-28)or, in other words, to pay it forward.

In sociology, this notion is generally known as reciprocity, i.e. the idea that people will behave towards each other in similar ways - for instance, responding to amicable behavior with similar benevolence of their own, while responding to aggression with retaliation. While reciprocity traditionally refers to one-on-one interaction, it can also be expanded in scope through the concept of generalized exchange (Yamagishi \& Cook, 1993). Generalized exchange occurs when an individual feels obliged to reciprocate another's action, not by directly rewarding his benefactor, but by benefiting another actor. Generalized exchange has been associated with the emergence of solidarity (Molm, Collett, \& Schaefer, 2007; Willer, Flynn, \& Zak, 2012), and recent experimental results by Tsvetkova \& Macy (2014) show that receiving generosity significantly increases the likelihood to be generous towards strangers.

For what concerns the dynamics at work on our empirical setting, I argue that generalized exchange dynamics such as the ones described above will come into play when entrepreneurs receive funding from angel investors. In fact, receiving a tangible contribution from an angel investor is likely to trigger the pay-it-forward mechanism, thereby encouraging entrepreneurs to become business angels themselves. ${ }^{11}$ Formally stated:

Proposition 1. Receiving funding from angel investors will make entrepreneurs more likely to become angel investors themselves, relative to receiving funding entirely from other sources.

${ }^{11}$ https://www.entrepreneur.com/article/243759 
In the remainder of the theory section, I explore the scope conditions of generalized reciprocity as it pertains to angel investing.

Homophily and in-group favoritism. Human behavior is characterized by homophily (McPherson et al., 2001); i.e. by the tendency to associate with others that are similar to us. Historically, this tendency towards homophily has resulted in inequality in organizations and markets alike; venture financing is no exception. For instance, empirical evidence suggests that startup ideas pitched by men are more likely to get funded, because most investors are men (Brooks, Huang, Kearney, \& Murray, 2014). Similarly, women are also at a disadvantage in that they tend to get fewer business referrals in male-dominated fields (Abraham, 2014). Other characteristics such as local affiliations can often drive homophily, as well (Dahl \& Sorenson, 2012): in China, for example, returnee entrepreneurs with school ties within the local community were found to do better than entrepreneurs with no such ties (Obukhova, Wang, \& Li, 2013). Shared affiliations such as these can create common ground that makes the development of social interaction more likely (McPherson et al., 2001). Similar dynamics are arguably at work in angel investing, ${ }^{12}$ as well: in a recent article, Mitteness, DeJordy, Ahuja, \& Sudek (2016) found that there is a general tendency for angel investors to team up with demographically similar others.

Here, I extend this line of inquiry by suggesting that homophily will moderate the generalized reciprocity dynamics described in the previous section; in practical terms, company founders will be especially likely to become angel investors if they received angel funding from individuals that are similar to them. This argument resonates with the existing literature on the subject: for instance, Chiang \& Takahashi (2011) found that ties among members of a social group

\footnotetext{
${ }^{12} \mathrm{http}$ ://www.forbes.com/sites/geristengel/2014/05/28/entrepreneurship-and-angel-investing-are-breaking-barriersfor-women/\#79c627c01ccc
} 
favor the emergence of generalized exchange within the group, which goes to show that being connected with individuals that are similar to us is a strong predictor of pay-it-forward reciprocity. Social identity theory (Tajfel \& Turner, 1986) also supports the idea that individuals tend to treat members of their in-group more favorably. This phenomenon, typically known as in-group favoritism (Billig \& Tajfel, 1973), makes individuals more likely to behave favorably towards members of groups that define their own social identity (such as race, gender, or school/workplace affiliations); in turn, receiving a favor from an in-group member makes generalized reciprocity more likely to take place (Yamagishi et al., 1999). Finally, recent developments in social network analysis support the idea that homophily can be instrumental in favoring the diffusion of behavior through social connections (Aral, Muchnik, \& Sundararajan, 2009; Centola, 2011). Based on the above arguments, I would expect entrepreneurs who receive funding from individuals similar to them to be especially likely to pay it forward by providing angel funding to others. While this argument is likely to apply broadly to a wide range of socioeconomic characteristics, including race, occupation, and social class, hereafter I focus on variables that can be realistically measured with our data: gender, school ties, and location. I discuss each of these in detail below.

\section{Gender.}

"I decided to join a specialized angel group because, as a woman, I knew that if I did not invest in women, no one else would. And my hope is that if I do that, then maybe one day they will eventually do the same and finance other women, too."

In the extant literature, gender effects have been shown to be pervasive in organizations and market settings, as well as in entrepreneurship more specifically. For starters, there exists a well-known gender gap in entrepreneurship, which reinforces the perception of the latter as a male-dominated field: indeed, in the United States only 20.5 percent of employer firms are owned by female entrepreneurs, compared to 64.5 percent that are owned by male entrepreneurs and 15 percent that 
are equally owned, according to the 2014 Annual Survey of Entrepreneurs. ${ }^{13}$ In addition, because entrepreneurship involves risk-taking to a degree which often clashes with traditional gender roles, women have traditionally been either reluctant or unable to pursue it; moreover, the lack of supportive institutions such as childcare or paid family leave may pose an additional hurdle (Thebaud, 2015).

While there is an extensive literature on gender homophily (Ruef, Aldrich, \& Carter, 2003), and by extension sex segregation, in the workplace (e.g. Bielby \& Baron, 1986; Dezso, Ross, \& Uribe, 2016; Ibarra, 1992), the literature on gender effects in entrepreneurship is in its infancy (Aldrich, 1989; Stuart \& Sorenson, 2007). Some notable instances of research in this area include Brooks et al. (2014), who found that investors show a preference for pitches by male entrepreneurs vis-à-vis pitches made by female entrepreneurs, and all the more so if the former are more attractive; Abraham (2014), who showed that female entrepreneurs receive fewer benefits from social capital and networking than male entrepreneurs; and Greenberg \& Mollick (2017), who found gender homophily to be a key factor in crowdfunding dynamics, so that individuals are more likely to crowdfund ventures founded by individual whom they perceive to be like them, a fact which leads to women financing other women more frequently.

For what pertains to this paper and its theoretical framework, and based on the arguments made in the previous section, I will argue that—ceteris paribus—generalized reciprocity will be moderated by gender homophily, so that entrepreneurs will be more likely to become angel investors when they are financed by an angel investors of the same gender. Indeed, because individuals are more likely to imitate the behavior of those they perceive as similar-which in our case triggers generalized reciprocity-I would expect entrepreneurs to be more likely to follow the

\footnotetext{
${ }^{13}$ http://www.kauffman.org/blogs/growthology/2016/09/the-gender-gap-remains-large
} 
example of the business angels who are similar to them along one or more dimensions. And since gender has been extensively shown to be a key dimension of homophily (McPherson et al., 2001), entrepreneurs should be comparatively more likely to transition to angel investing when they are financed by someone of their same gender. More formally:

Proposition 2a. Entrepreneurs will be more likely to become angel investors when they receive angel funding from investors of their same gender, relative to: a) baseline; b) entrepreneurs whose angel investors are of the opposite gender.

\section{School ties.}

“...when people are connected by an affinity—alumni groups, for example - they are flatout more willing to help one another. [...] Somebody who sold a company for a billion dollars is infinitely more likely to serve on a board of a seed company when they share a common bond."

The second of these variables is the presence of a school tie, i.e. whether entrepreneurs and the angel investors founding their ventures attended the same educational institution. Shared organizational foci among individuals — such as a common workplace, or educational institutionhave long been recognized as inducing friendship, shared attitudes, and behavioral homophily (McPherson et al., 2001); in other words, individuals are especially likely to socialize with, and behave similarly to, people with whom they share such affiliations. For instance, Galaskiewicz \& Shatin (1981) found that shared committee memberships had a strong effect on patterns of covoting. Kacperczyk (2013) traced back the decision to enter entrepreneurship to the social influence exerted by one's university peers. ${ }^{14}$ In all, individuals are especially likely to mimic the

\footnotetext{
${ }^{14}$ See also Lerner \& Malmendier (2013).
} 
behavior of others with whom they share one or more organizational foci. For this reasons, I would argue that when an entrepreneur's ventures are financed by a business angel, the presence of a school tie between the entrepreneur and investor will increase the likelihood of generalized reciprocity being triggered, thereby favoring the entrepreneurs' transition to angel investing. More formally:

Proposition $2 \boldsymbol{b}$. Entrepreneurs will be more likely to become angel investors when they receive angel funding from investors that went to their same school, relative to: a) baseline; $b$ ) entrepreneurs whose angel investors did not go to the same school as them.

\section{Location.}

"Not only is investing locally more convenient, but it is also a way for me to give back and contribute to the New York ecosystem, which has given me so much."

A third and final variable of interest here is location. The importance of entrepreneurs' "social attachment to place" is well documented in the organizational literature (Dahl \& Sorenson, 2010, 2012). Entrepreneurs in fact rely on a broad set of local ties: these include family and friends for social support, as well as professional connections that help them to gather the resources they need to succeed (Dahl \& Sorenson, 2009), including venture funding. Because entrepreneurs build on the local community in both their personal and professional lives, they are bound to experience an increased sense of obligation when they receive assistance from sources within the community. Conversely, when they receive funding from an investor located elsewhere they are more likely to frame the transaction in purely economic terms, which will not elicit the same desire to "pay it forward". Therefore, I would argue that when an entrepreneur is financed by a business angel 
hailing from the same area, he or she will feel compelled to give back to the community, and thus be more inclined to become an angel investor in turn. More formally:

Proposition 2c. Entrepreneurs will be more likely to become angel investors when they receive angel funding from investors that are located in their same metropolitan area, relative to: a) baseline; b) entrepreneurs whose angel investors are not co-located.

The reproduction of homophily in angel investing. After examining the antecedents of entry into angel investing, I now turn to the following question: how does the pattern of angel investments received by entrepreneurs affect the patterns of angel investment made by the entrepreneurs, once they transition to angel investing? Here, I will argue that if venture financing relationships are characterized by homophily, then similarly homophilous investment patterns should be observed once the entrepreneurs who received angel funding transition to angel investing themselves. In other words, I would expect venture funding choices to be reproduced across generations of entrepreneurs. In this regard, the organizational literature provides ample evidence for the social reproduction of individual decisions, most notably for what pertains to occupational choices and hiring. With respect to the former, beginning with Blau, Gustad, Jessor, Parnes, \& Wilcock (1956), scholars have increasingly linked occupational choices with social influence, arguing that parental role models, as well as influence from mentors and teachers, often play a significant role in shaping the careers that individuals pursue. In a similar fashion, studies of homosocial reproduction (Kanter, 1977; Rivera, 2013) have shown that gender imbalances in the workplace are reproduced because people tend to select individuals who are similar to themselves. Because social similarity breeds trust and makes the establishment of social ties less risky and 
more predictable, homophily emerges as a significant predictor of selection and promotion decisions within organizations. More recent work has highlighted the same dynamics in the context of hiring decisions (Rivera, 2012), showcasing how managers show a preference for candidates who are culturally similar to themselves - a process which in turn reproduces organizational culture and ensures its stability over time. At a societal level, dynamics such as these have been associated with the maintenance_ of elite power structures and inequality, as well (Khan, 2012; Rivera, 2015).

For what pertains to the empirical setting at hand, I advance the argument that because angel investing is a process that requires socialization, entrepreneurs are likely to be influenced by the style and preferences of angel investors who finance them to a significant degree. Because individuals are likely to imitate socially proximate alters (Coleman, Katz, \& Menzel, 1957; Kacperczyk, 2013), under conditions of homophily the similarities between angel investor and founder are likely to be reproduced in the investments made by the latter. More specifically, entrepreneurs who are financed by angel investors of the same gender might become more prone to do the same, based on the homosocial reproduction arguments discussed above (Kanter, 1977). The same line of argument applies to receiving funding from someone within an alumni network as well, because having attended the same educational institution creates shared ground which also favors the reproduction of homophily, making entrepreneurs more inclined to look within the network for investment opportunities. And in the case of co-location, receiving funding from an angel investor within the community can also engender feelings of indebtedness, which in turn might make the entrepreneur more prone to finance other local entrepreneurs down the line. Mirroring my earlier arguments concerning homophily as a reciprocity moderator, therefore, I will argue that when an entrepreneur is financed by an angel investor who is either: a) of the same 
gender; b) an alumnus of the same school as the entrepreneur; c) co-located, he or she will be more likely to finance other entrepreneurs with the same traits. More formally:

Proposition 3a. Entrepreneurs who received angel funding from investors who are of their same gender will be more likely to provide angel funding to entrepreneurs of the same gender.

Proposition 3b. Entrepreneurs who received angel funding from investors who went to their same university will be more likely to provide angel funding to entrepreneurs who went to their same university.

Proposition 3c. Entrepreneurs who received angel funding from investors that are located in their same metropolitan area will be more likely to provide angel funding to entrepreneurs within the same metropolitan area.

\section{DATA AND VARIABLES}

Quantitative data. The primary data for this study come from Crunchbase, an online data source for information about new high-tech ventures, venture capital and notable individuals in the startup ecosystem (such as founders and investors). I used Crunchbase primarily to: 1) identify all VC-backed tech startups in the United States; ${ }^{15}$ 2) create a list of all the entrepreneurs who founded these companies; 3) identify angel investments made by entrepreneurs in the sample.

\footnotetext{
${ }^{15}$ Choosing to focus the analysis on VC-backed entrepreneurs provides a useful way to limit the size of the sample, as collecting LinkedIn data is expensive and the available information is likely to be of higher quality for those ventures that have been backed by venture capital at some point.
} 
Table 1 reports a summary of the information that can be gathered from CrunchBase about individuals, organizations, and funding rounds.

Insert Table 1.1 about here

With respect to existing datasets that have been used to study entrepreneurship and venture capital, Crunchbase is unique in that it relies on crowdsourcing, whose main advantages include diversity and timeliness of information, as well as broader coverage. However, unlike other crowdsourced platforms — such as Wikipedia_ contributions are carefully examined by the editorial staff to ensure the accuracy and quality of each data point. Furthermore, while most commonly used datasets only collect data from a limited set of investors or startups, CrunchBase has a broader scope of coverage because it triangulates data from multiple sources including press releases, SEC filings, and venture databases (Ter Wal et al., 2016; Wang, Pahnke, \& McDonald, 2018). While CrunchBase's coverage of companies and funding rounds is extensive, however, its main downside of CrunchBase is a paucity of information on individuals - investors and entrepreneurs alike. To remedy this latter shortcoming of my primary data source, for each entrepreneur I then collected additional data from LinkedIn, including information about career history, educational affiliations, and location. ${ }^{16} \mathrm{I}$ also used this data to match entrepreneurs, startups, and universities to the respective Metropolitan Statistical Areas (MSA) - as defined by the U.S. Census Bureau. While the majority of past work has relied on small samples or anecdotal data, Crunchbase will allow me to test my hypotheses on a sample of approximately 10,000 domestic entrepreneurs who founded companies in the United States between the 1990s and the present day whose ventures

\footnotetext{
${ }^{16}$ Because LinkedIn does not allow automated scraping of their data, this information had to be collected manually.
} 
were funded — among others — by about 2,700 unique angel investors; such a large sample is bound to strengthen the reliability and generalizability of my results in a substantial manner. Further, the integration of Crunchbase and LinkedIn — which provides information about each founder's education and career trajectory—results in a dataset of unprecedented size, depth, and scope.

Interview data and fieldwork. In addition to the archival data described above, to gain a more in-depth knowledge of the market for angel investment I sought to incorporate qualitative data in the form of interviews and fieldwork. With respect to the former, I conducted 15 interviews with angel investors: my sample primarily comprises individuals based in New York City and the Tri-State metropolitan area, although I was also able to interview angels based in other areas of the country, such as the San Francisco Bay Area, Boston, and Atlanta. These interviews were used primarily to inform hypothesis development and to gather qualitative evidence on those theoretical mechanisms that are not easily tested by means of regression analysis. Moreover, I also attended several angel investor meetings in New York City, which were helpful both to gain further interview contacts through snowball sampling and to strike informal conversations with angel investors about their career, interests, and expertise. Attending angel group meetings regularly also allowed me to observe angel investors and entrepreneurs interacting "in the wild" during pitches, to explore the socialization patterns among angels with different professional backgrounds, as well as to gain insights concerning the various activities that angel investors normally engage in —either alone or in groups - such as due diligence, following up with entrepreneurs, and "deep dives" into specific investment opportunities. Finally, in May 2017 I also had the chance to take part in the Angel Capital Association Annual Meeting, the largest meeting of angel investors in the world. In so doing, I had a chance to interact with angel investors from several different countries, as well 
as get acquainted with the various aspects of angel investing that, as a layman, I was originally not familiar with.

Methods. As for the choice of empirical models, I test Propositions 1, 2a, 2b, and 2c by means of event-history models - and more specifically, Cox proportional hazard models - to the population of tech entrepreneurs identified through Crunchbase. As the main focus of the study is the transition from entrepreneurship to angel investing, entrepreneurs are assumed to enter the sample when they found their first venture and exit it when they make their first angel investment. In this regard, testing Proposition 1 would entail assessing whether receiving angel fundingoperationalized as the number of investments by individuals that the entrepreneur's ventures have received-has an impact on an entrepreneur's likelihood to take up angel investing. As far as Propositions 2a, 2b, 2c are concerned, they require exploring whether homophily-operationalized through gender, co-location and school ties - moderates the relationship described in Proposition 1, which can be easily tested through interaction effects. Entrepreneurs are assumed to enter the observation window in the year in which they found their first company, and they exit the sample either when they make their first angel investment or in 2015 , whenever is later. ${ }^{17}$ As I am interested in what makes entrepreneurs decide to take up angel investing, as opposed to established investors who found companies, I excluded from the sample those entrepreneurs that began angel investing before founding their first company. Also, I consider all investments in startup companies that were made by individuals as angel investments, regardless of how they are coded in CrunchBase, provided that the individuals did not invest in their own company. This is because there seems to be a substantial amount of variance in how early funding rounds are named, ${ }^{18}$ so for

\footnotetext{
${ }^{17}$ Because the data were collected in 2016, my observation window ends in 2015. Further, because CrunchBase coverage is spotty before 1995, I begin observing entrepreneurs in 1995.

${ }^{18}$ http://qz.com/124206/hey-startups-naming-your-funding-round-wrong-could-cost-you-millions/
} 
the purposes of this analysis angel investments are defined as investments in private companies made by individuals, regardless of stage or funding round label (Shane, 2008). On the other hand, I only consider investments made by individuals as angel investments; in so doing, I deliberately exclude syndicates such as angel groups. Here, the dependent variable in all models is the probability to transition to angel investment. For what concerns independent variables, for Proposition 1 the relevant variable is the number of investments made by angel investors that were received by the focal entrepreneur's ventures, operationalized as a simple count. For Proposition 2a, the independent variable used is the number of investments received by angel investors of the same gender as the entrepreneur. Proposition 2b's relevant independent variable is instead the number of investments received by the focal entrepreneur's ventures that were made by an investor who attended the same school as the entrepreneur, which allows me to test for the effect of school ties. Finally, Proposition $2 \mathrm{c}$ can be tested by means of a count for the number of investments received by the focal entrepreneur's ventures that were made by an investor who is located within the same MSA. To rule out potential confounders, I also include a number of controls in my analysis. First, to account for the fact that female entrepreneurs might exhibit different inclinations toward angel investing than male entrepreneurs, I include a dummy variable for gender of the entrepreneur whose value is 1 for females and 0 for males. Second, to disentangle the effect of angel investing vis-à-vis funding by other sources, I include a variable for the number of investments made by organizations (such as VCs and other funds) in the entrepreneur's ventures. Moreover, because the educational background of entrepreneurs is likely to influence their investing choices as well as the decision to become business angels, I include dummies for whether the entrepreneur majored in business or a STEM subject. Furthermore, the decision to become an investor is likely a function of the entrepreneurs' past success; to account for this, I include a set 
of variables pertaining to the entrepreneurial experience of the focal founder: a) number of founded companies; b) number of founded companies that went public; c) number of founded companies that were acquired; d) number of founded companies that closed. Regrettably, I do not have information about the personal wealth of individual entrepreneurs, but I am hopeful that the latter will be adequately proxied by the above variables, as these are strong correlates of both entrepreneurial and financial success. Finally, because more successful investors could conceivably be more likely to "spawn" new angel investors by financing ventures that are especially likely to succeed, I include some of the angel investors' characteristics as controls: a count of the companies founded by the angel investors founding the focal entrepreneur that 1 ) were acquired; 2) went public. Table 2 reports the descriptive statistics for these variables, as well as their bivariate correlations.

Insert Table 1.2 about here

For what concerns Propositions $3 \mathrm{a}, 3 \mathrm{~b}$, and $3 \mathrm{c}$, the dependent variables are the number of investments made by the entrepreneurs in the sample towards: a) ventures founded by other entrepreneurs of the same gender; b) ventures founded by entrepreneurs that went to the same school as the focal founder; c) ventures founded by entrepreneurs that are located within the same geographical area as the focal founder. Because the dependent variables are counts, and because their mean does not equal their variance — thereby violating one of the key assumptions of Poisson regression-I test these propositions using panel negative binomial models. Here, the relevant independent variables here are count variables for the number of investments received from: a) angels who are of the same gender; b) angels who went to the same university as the focal founder; 
c) angels that are located within the same metropolitan area as the focal founder. Moreover, these models include the same control variables previously reported, although all independent variables and some control variables had to be orthogonalized through a modified Gram-Schmidt orthogonalization procedures to avoid multicollinearity issues, since they were found to be highly correlated. Descriptive statistics for these variables, as well as their bivariate correlations, are reported in Table 3 .

Insert Table 1.3 about here

\section{RESULTS}

Insert Table 1.4 about here

For what concerns the first part of the study, my model results are reported in Table 4. Model 1 includes just the basic control variables, while Model 2 adds the variable for funding received by organizations, and Model 3 adds the first independent variable, i.e. the number of angel investments received. The coefficient for the latter is positive and significant, indicating that a unit increase in the number of angel investments received by founders makes their chances of becoming angel investors increase by 16.4 percent relative to baseline. Further, receiving funding from an organization only improves the odds by 3.3 percent, indicating that angel funding is more likely to trigger generalized reciprocity than funding from other sources. In this model, it is also interesting to note how gender has a significant and negative effect, indicating that, on average, female entrepreneurs are 48.4 percent less likely than male entrepreneurs to become angel investors. The model also shows that more successful entrepreneurs, with success measured through IPOs and 
acquisitions, are more likely to become angel investors, presumably because of the wealth that likely resulted from such events. Interestingly enough, entrepreneurs' education characteristics appear to be relevant, as well: STEM-educated founders and founders holding more advanced degrees, other things being equal, appear to be less likely to become angel investors. ${ }^{19}$

To test the gender homophily assertion in Proposition 2a, Model 4 includes the first independent variable, i.e. the number of investments received by the founder from investors that are of the same gender. The coefficient is positive and significant, indicating that a unit increase in the number of investments received from angels of the same gender increases the odds of the focal founder becoming an angel investor by 26.8 percent relative to baseline. Furthermore, a Ztest (Clogg, Petkova, \& Haritou, 1995) reveals that this coefficient is significantly different from the one reported in Model 3 for the number of angel investments received, which shows that the presence of gender homophily magnifies the effect of reciprocity on the likelihood of becoming an angel investor, as predicted. In all, this pattern of results is consistent with the gender homophily hypothesis. Model 5 adds the number of angel investments received from investors having a school tie with the founder. Once again, the coefficient is positive and significant, indicating that an additional investment received by someone that the entrepreneur went to school with improves the odds of the latter becoming an angel investor by 59.3 ; once again, a Z-test reveals that this coefficient is significantly greater than the one reported in Model 3. Finally, Model 6 adds the final variable: the number of investments received by investors located within the same MSA. Once again, the coefficient is positive and significant, which suggests that receiving funding from a colocated investor improves the odds of the focal founder becoming an angel investor by 43.5 -like in the case of the previous two coefficients, this one is also significantly different from the one in

\footnotetext{
${ }^{19}$ This table does not include a full model because the last four variables in the table are highly correlated.
} 
Model 3. It is possible, however, that these results might be at least partially driven by factors specific to the entrepreneurial ecosystems or the communities in which startups are located. To account for such unobserved, time-invariant heterogeneity at the local level, I also coded MSA (Metropolitan Statistical Area) dummies for each of the founders, and ran separate models that include them. These results, reported in Table 5, do not differ significantly from those previously reported, so it is reasonable to assume that our results are not driven by community-specific factors.

Insert Table 1.5 about here

For what concerns Propositions 3a, 3b, and 3c, I ran three separate sets of panel negative binomial models with three different dependent variables: 1) the number of investments made by the entrepreneurs in the sample towards founders of the same gender; 2) the number of investments made by the entrepreneurs in the sample towards founders with whom they have school ties; 3) the number of investments made by the entrepreneurs in the sample towards founders in the same MSA. These are reported in Tables 6, 7, and 8.

Insert Tables 1.6, 1.7, and 1.8 about here

In each of these tables, the first model reports just basic controls, while the second model adds the number of investments by organizations and the third the number of investments by angels. Finally, the fourth model adds the independent variable of interest. Table 6 and 8 show coefficients that are positive and significant, indicating that: a) entrepreneurs who were financed by angel investors of their same gender were more likely to finance other entrepreneurs of the same gender; 
and b) entrepreneurs who were financed by co-located investors were more likely to finance other entrepreneurs within the same MSA. The same does not hold, however, in the case of school ties.

Overall, all propositions are supported with the exception of Proposition $3 \mathrm{~b}$. While no conclusions can be drawn about the effect of school tie homophily on the likelihood of financing other entrepreneurs within the same alumni network, I would conjecture that the lack of statistical power might be a factor here, given it is extremely rare to observe the (less than a thousand) entrepreneurs in the second-stage sample finance other entrepreneurs within the same alumni network.

\section{DISCUSSION}

While angel investing is arguably a consequential phenomenon for both venture financing and entrepreneurial ecosystems at large (Kerr et al., 2014), it has received surprisingly scarce attention from entrepreneurship scholars so far. And while this lack of attention is most likely a byproduct of data availability, which is in turn due to the informal nature of many angel investments, further research is both warranted and needed. In this paper, I start from the basic premise that a majority of angel investors have entrepreneurial experience to study the process whereby entrepreneurs decide to transition to angel investing, relying on well-established sociological constructs such as generalized reciprocity and homophily. In so doing, I find support for the basic premise of my theory, i.e. that startup founders are more likely to transition to angel investing if they received funding from angel investors, relative to other forms of funding, which is consistent with the idea of generalized reciprocity. While the effect at a population level is quite small—every additional angel investment increases the likelihood of transitioning to angel investing by 16.4 percent, on average - the effect is much stronger under conditions of homophily, so that entrepreneurs are 
more likely to transition to angel investing if they were financed by angel investors who: a) were of the same gender; b) went to the same school as the entrepreneur; c) are from the same metropolitan area. This is because- $\mathrm{I}$ argue — generalized reciprocity is more likely to arise when individuals are the direct recipients of generosity, rather than simple witnesses to it (Tsvetkova \& Macy, 2014); furthermore, similarity between angel investors and founders across the outlined dimensions makes the former's example more likely to be followed, thereby increasing the likelihood of the latter transitioning to angel investing. Additionally, my results show that when venture financing is provided under conditions of homophily, entrepreneurs are more likely to provide funding to other entrepreneurs along similar lines; while no effect was found for school ties, significant results were obtained for co-location and gender. Within the organizational literature, this is reminiscent of the literature on imprinting (Marquis \& Tilcsik, 2013), and it also resonates with earlier arguments made concerning gender segregation (Brass, 1985; Ibarra, 1992) and the role of co-location (Audia, Freeman, \& Davidson, 2006; Davis \& Greve, 1997) in the diffusion of behaviors. Due to its theoretical scope and empirical setting, I believe this paper makes several contributions to both our understanding of entrepreneurial and venture financing dynamics and the broader literature on the sociological underpinnings of organizations and markets, which I detail below.

Contributions to the organizational sociology literature. For what pertains to the sociology and organizational theory literature, the present study aims to shed light on how wellestablished sociological constructs such as homophily (McPherson et al., 2001) and generalized reciprocity (Takahashi, 2000) are closely interrelated. Leveraging angel investing as an empirical setting, my work does in fact show that generalized reciprocity is more likely to occur under conditions of homophily, i.e. when investors and founder are of the same gender, are co-located, 
or went to the same school. What these seemingly disparate circumstances have in common is that they create shared ground between the investors and the founder, magnifying the sense of obligation experienced by the individual who receives assistance and contributing to make the individual more likely to reciprocate and pay it forward.

Additionally, this research could also broadly be of interest to scholars working on the topic of careers and, more specifically, on occupational choices and their reproduction (Blau et al., 1956; Levine, 1976). By showing how generalized reciprocity drives entrepreneurs financed by business angels to become angel investors in turn, my work informs theories of career choice by highlighting the role played by contextual factors, with specific reference to the exposure to angel investing during one's entrepreneurial career. This is consistent with the long-standing idea that occupational choices are determined to a significant degree by exposure to certain professions over others, for example through one's parents (Pablo-Lerchundi, Morales-Alonso, \& GonzálezTirados, 2015) or peers (Falck, Heblich, \& Luedemann, 2012); issues such as these are therefore of potential interest to both entrepreneurship scholars (Burton, Sørensen, \& Dobrev, 2016; Mungai \& Velamuri, 2011; Sørensen, 2007) and social scientists more broadly. Further, by highlighting the role that homophily plays in the reproduction of occupational choice, this paper also furthers theory in this area, underlining the conditions under which certain behaviors are more or less likely to be imitated.

Contributions to entrepreneurship and policy. For what pertains to the entrepreneurship field more specifically, my work aims to illuminate the social motivations behind angel investing; a topic has received scant attention from entrepreneurship scholars so far, despite the prevalence of former entrepreneurs among angel investors. I believe my work makes valuable contributions to the entrepreneurship field in that it brings in fresh perspectives from sociology to explain the 
transition between entrepreneurship and angel investing, which will hopefully result in a more robust theory. In so doing, this paper also invites attention to a variety of topics that have received scant attention up to this point, including (but not limited to): the relationship between entrepreneurs and their ecosystems, the specificities of angel investing vis-à-vis other forms of venture financing, and the role that geographic and community factors play in angel investing. Furthermore, as far as entrepreneurship policy is concerned, my findings can inform legislation designed to catalyze the transition to angel investing, thereby favoring the financing of new ventures and spurring economic development. My findings in fact show that—in a way-angel investing breeds more angel investing, which in turn results in higher level of overall venture financing and, presumably, in more successful ventures, based on Kerr et al.'s (2014) findings; all of the above factors, which are very desirable from the local community standpoint, have the potential of unleashing the growth of entrepreneurial ecosystems.

Limitations and directions for future research. As always, the contributions of this study must be appreciated in light of its limitations. For instance, the study sample—while large and reasonably representative of the high-tech entrepreneurial ecosystem-only comprises those startup founders whose ventures have been backed by VC at any point. The sample is therefore made up of reasonably successful individuals, who are likely to be wealthier than the general population of entrepreneurs, and for this reason they are perhaps more likely to become angel investors. On the other hand, the costs involved in the manual LinkedIn data collection, and the fact that the information available on Crunchbase is of higher quality for such companies, dictated this empirical choice. I have no reason, however, to believe that the pattern of empirical results presented here would not hold in the broader entrepreneurial population. Another limitation of the data concerns the lack of detailed financial information for individuals and the companies they 
founded. It could very well be that acquisitions and IPOs that netted more money for the founders might boost the odds of the latter becoming angel investors substantially. Nonetheless, I believe that controlling for the number of successful acquisitions and IPOs that involve the founder's ventures is a reasonable proxy for the factors described above. Further research could overcome this limitation by collecting better data that includes more detailed information on individuals, which would also allow for enlarging the sample even further to include individuals who never received venture capital funding.

For what concerns new theoretical avenues of inquiry, scholars could expand on these findings by usefully examining the role of other moderating factors in the emergence of generalized reciprocity with respect to the transition from entrepreneurship to angel investing. Social capital at the community level is of particular interest here, given that extant scholarly work has found social capital to be associated with a higher prevalence of entrepreneurship (Kwon, Heflin, \& Ruef, 2013), because higher levels of social trust and membership in voluntary associations facilitate the transition to entrepreneurship. Much in the same way, communities with a higher density of nonprofit organizations exhibit a stronger relationship between venture capital and innovation (Samila \& Sorenson, 2017). Overall, I would expect communities characterized by higher levels of social capital —as measured by social trust and participation in nonprofit organizations - to provide greater opportunities for generalized reciprocity, as well. In such communities - as opposed to communities with lower levels of social capital—I would then expect entrepreneurs who received angel funding to be especially likely to become angel investors themselves. In fact, social trust facilitates the free flow of information across social groups, highlighting the opportunities — rather than the risks—of doing business with others, which will encourage angel investing. 
Table 1.1. Summary of information available on CrunchBase.

\begin{tabular}{|c|ll|}
\hline \multirow{5}{*}{ Individuals (entrepreneurs/investors) } & Location & Companies founded \\
& Gender & Investments \\
& Date of birth & Educations \\
& Biographical sketch & News \\
& TechCrunch media coverage & Event appearances \\
& Past positions & Awards \\
& Board \& advisory roles & \\
\hline \multirow{5}{*}{ Companies } & Acquisitions & Investments \\
& IPO/ Stock & Current team \\
& & Board members and \\
& Location of HQ & advisors \\
& Company description & Products \\
& Categories & Divisions \\
& Founding date & News \\
& Number of employees & Competitors \\
& TechCrunch media coverage & Partners \\
& Funding rounds & Past team \\
& Investors & Event appearances \\
\hline \multirow{5}{*}{ Funding rounds } & Funding type & Date \\
& Money raised & Investors \\
& Valuation & Related coverage \\
\hline
\end{tabular}


Table 1.2. Descriptive statistics and bivariate correlations for the first part of the study.

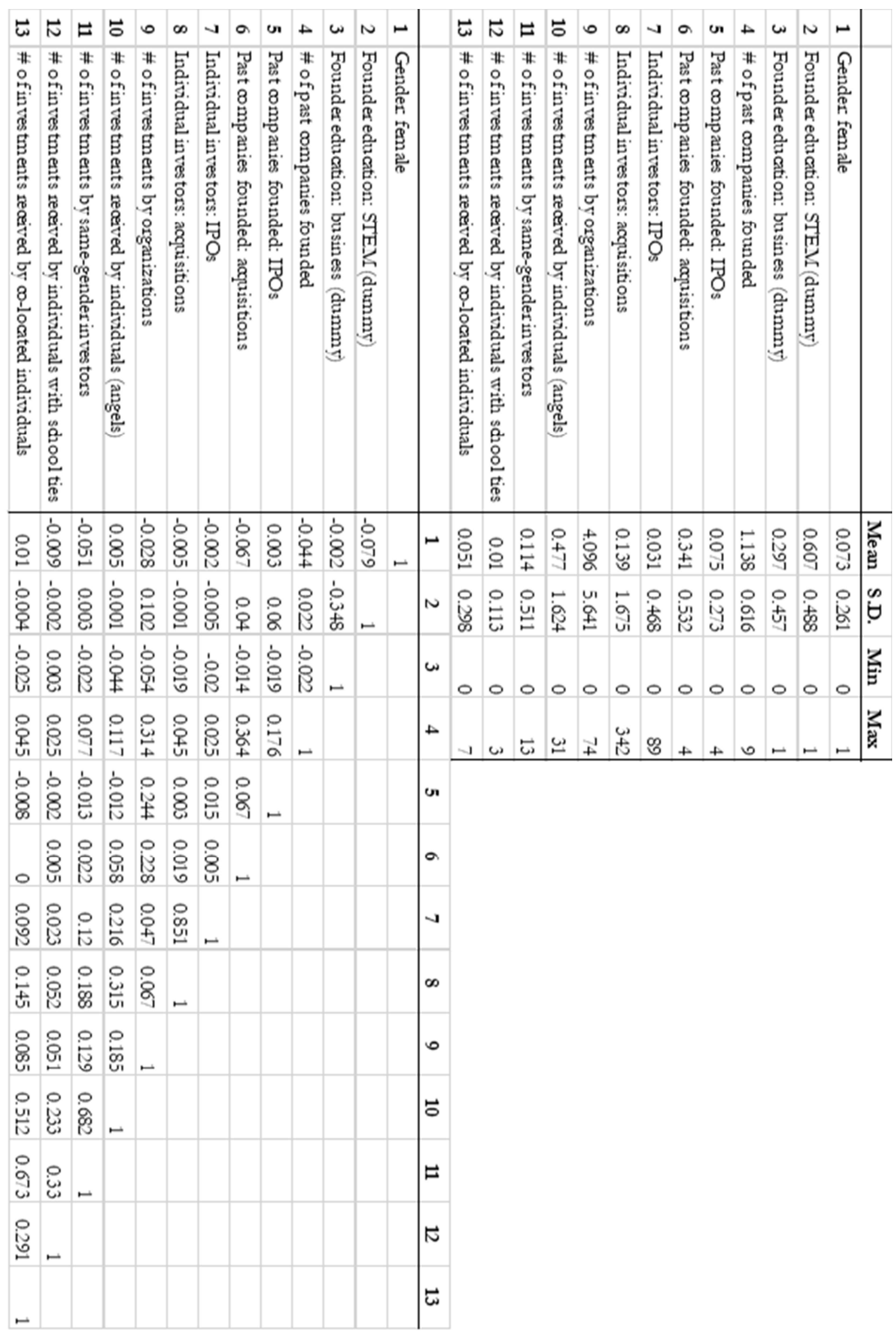


Table 1.3. Descriptive statistics and bivariate correlations for the second part of the study.

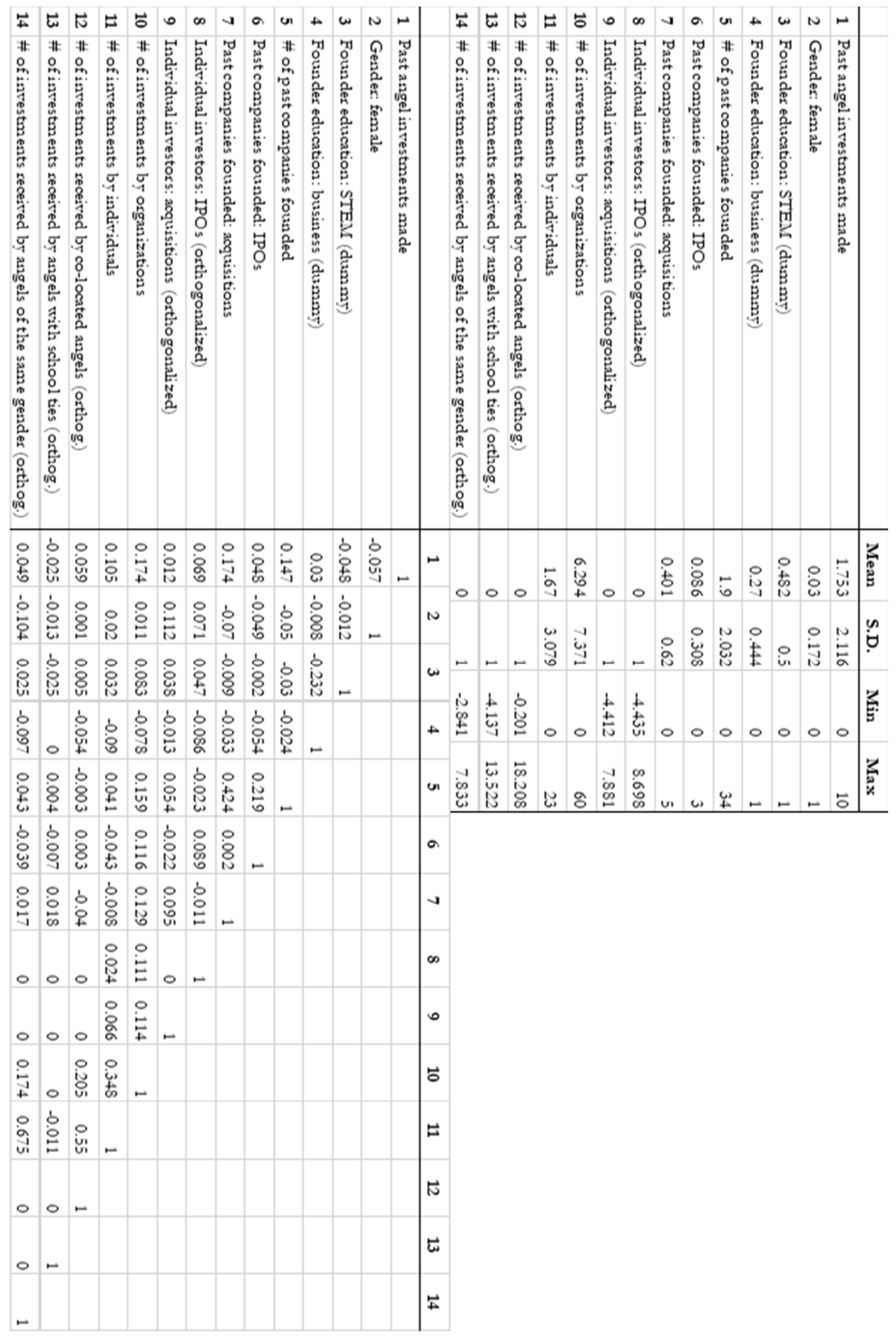


Table 1.4. Results for Cox proportional hazards event-history models for the hazard of transitioning.

\begin{tabular}{|c|c|c|c|c|c|c|}
\hline DV: hazard of entry into angel investing & & & & & & \\
\hline VARIABLES & Model 1 & Model 2 & Model 3 & Model 4 & Model 5 & Model 6 \\
\hline \multirow[t]{2}{*}{ Gender: female } & $-0.513 *$ & $-0.484 *$ & $-0.506^{*}$ & $-0.438 *$ & $-0.478 *$ & $-0.487 *$ \\
\hline & -0.2 & -0.2 & -0.198 & -0.2 & -0.2 & -0.2 \\
\hline \multirow[t]{2}{*}{ Founder education: STEM (dummy) } & $-0.301 * *$ & $-0.355 * * *$ & $-0.343 * * *$ & $-0.352 * * *$ & $-0.354 * * *$ & $-0.357 * * *$ \\
\hline & -0.093 & -0.096 & -0.097 & -0.096 & -0.096 & -0.096 \\
\hline \multirow[t]{2}{*}{ Founder education: business (dummy) } & -0.131 & -0.109 & -0.068 & -0.1 & -0.111 & -0.099 \\
\hline & -0.101 & -0.104 & -0.105 & -0.105 & -0.104 & -0.104 \\
\hline \multirow[t]{2}{*}{ \# of past companies founded } & $0.186^{* *}$ & $0.190^{* *}$ & $0.163 * *$ & $0.174^{* *}$ & $0.189^{* *}$ & $0.185^{* *}$ \\
\hline & -0.061 & -0.06 & -0.062 & -0.061 & -0.06 & -0.06 \\
\hline \multirow[t]{2}{*}{ Past companies founded: IPOs } & $0.887 * * *$ & $0.538^{* *}$ & $0.703 * * *$ & $0.589 * * *$ & $0.547 * *$ & $0.581 * *$ \\
\hline & -0.148 & -0.179 & -0.169 & -0.177 & -0.178 & -0.177 \\
\hline \multirow[t]{2}{*}{ Past companies founded: acquisitions } & $0.995^{* * *}$ & $0.907 * * *$ & $0.899 * * *$ & $0.916^{* * *}$ & $0.914 * * *$ & $0.918 * * *$ \\
\hline & -0.077 & -0.081 & -0.081 & -0.082 & -0.081 & -0.08 \\
\hline \multirow[t]{2}{*}{ Individual investors: IPOs } & $0.356+$ & $0.360+$ & $0.357 * *$ & $0.342 *$ & $0.364+$ & $0.371^{*}$ \\
\hline & -0.214 & -0.199 & -0.118 & -0.16 & -0.191 & -0.174 \\
\hline \multirow[t]{2}{*}{ Individual investors: acquisitions } & -0.087 & $-0.088+$ & $-0.223 * * *$ & $-0.087^{*}$ & $-0.089+$ & $-0.095^{*}$ \\
\hline & -0.056 & -0.052 & -0.064 & -0.042 & -0.05 & -0.046 \\
\hline \multirow[t]{2}{*}{ \# of investments by organizations } & & $0.040 * * *$ & $0.033 * * *$ & $0.037 * * *$ & $0.040^{* * *}$ & $0.038 * * *$ \\
\hline & & -0.007 & -0.008 & -0.007 & -0.007 & -0.007 \\
\hline \multirow[t]{2}{*}{ \# of investments received by individuals (angels) } & & & $0.164 * * *$ & & & \\
\hline & & & -0.02 & & & \\
\hline \multirow[t]{2}{*}{ \# of investments by same-gender investors } & & & & $0.268^{* * *}$ & & \\
\hline & & & & -0.035 & & \\
\hline \multirow[t]{2}{*}{ \# of investments received by individuals with school ties } & & & & & $0.593^{*}$ & \\
\hline & & & & & -0.23 & \\
\hline \multirow[t]{2}{*}{$\#$ of investments received by co-located individuals } & & & & & & $0.435^{* * *}$ \\
\hline & & & & & & -0.072 \\
\hline Observations & 49,487 & 48,939 & 48,939 & 48,939 & 48,939 & 48,939 \\
\hline
\end{tabular}

Robust standard errors in parentheses

$* * * \mathrm{p}<0.001, * * \mathrm{p}<0.01, * \mathrm{p}<0.05,+\mathrm{p}<0.1$ 
Table 1.5. Results for Cox proportional hazards event-history models for the hazard of transitioning to angel investing with MSA dummies.

\begin{tabular}{|c|c|c|c|c|}
\hline \multicolumn{5}{|l|}{ DV: hazard of entry into angel investing } \\
\hline VARIABLES & Model 7 & Model 8 & Model 9 & Model 10 \\
\hline \multirow[t]{2}{*}{ Gender: female } & $-0.631 * *$ & $-0.572 * *$ & $-0.613 * *$ & $-0.620 * *$ \\
\hline & -0.214 & -0.216 & -0.215 & -0.215 \\
\hline \multirow[t]{2}{*}{ Founder education: STEM (dummy) } & $-0.436^{* * *}$ & $-0.443 * * *$ & $-0.449 * * *$ & $-0.448 * * *$ \\
\hline & -0.103 & -0.102 & -0.102 & -0.102 \\
\hline \multirow[t]{2}{*}{ Founder education: business (dummy) } & -0.071 & -0.098 & -0.105 & -0.095 \\
\hline & -0.11 & -0.11 & -0.109 & -0.109 \\
\hline \multirow[t]{2}{*}{ \# of past companies founded } & $0.161^{*}$ & $0.170 * *$ & $0.183 * *$ & $0.182 * *$ \\
\hline & -0.064 & -0.065 & -0.063 & -0.063 \\
\hline \multirow[t]{2}{*}{ Past companies founded: IPOs } & $0.771 * * *$ & $0.660 * * *$ & $0.625 * * *$ & $0.649 * * *$ \\
\hline & -0.178 & -0.186 & -0.188 & -0.186 \\
\hline \multirow[t]{2}{*}{ Past companies founded: acquisitions } & $0.829 * * *$ & $0.835^{* * *}$ & $0.827 * * *$ & $0.832 * * *$ \\
\hline & -0.085 & -0.086 & -0.085 & -0.085 \\
\hline \multirow[t]{2}{*}{ Individual investors: IPOs } & $0.350 * *$ & $0.330 *$ & $0.340+$ & $0.343 *$ \\
\hline & -0.114 & -0.152 & -0.177 & -0.165 \\
\hline \multirow[t]{2}{*}{ Individual investors: acquisitions } & $-0.203 * * *$ & $-0.085^{*}$ & $-0.085+$ & $-0.089 *$ \\
\hline & -0.06 & -0.04 & -0.046 & -0.043 \\
\hline \multirow[t]{2}{*}{ \# of investments by organizations } & $0.028 * * *$ & $0.032 * * *$ & $0.034 * * *$ & $0.033 * * *$ \\
\hline & -0.008 & -0.008 & -0.008 & -0.008 \\
\hline MSA dummies & Yes & Yes & Yes & Yes \\
\hline \multirow[t]{2}{*}{ \# of investments received by individuals (angels) } & $0.149 * * *$ & & & \\
\hline & -0.019 & & & \\
\hline \multirow[t]{2}{*}{ \# of investments by same-gender investors } & & $0.236^{* * *}$ & & \\
\hline & & -0.037 & & \\
\hline \multirow[t]{2}{*}{ \# of investments received by individuals with school ties } & & & $0.482 *$ & \\
\hline & & & -0.23 & \\
\hline \multirow[t]{2}{*}{ \# of investments received by co-located individuals } & & & & $0.362 * * *$ \\
\hline & & & & -0.077 \\
\hline Observations & 46,758 & 46,758 & 46,758 & 46,758 \\
\hline
\end{tabular}


Table 1.6. Panel negative binomial results for investments made towards founders of the same gender as the angel investor.

\begin{tabular}{|c|c|c|c|c|}
\hline \multicolumn{5}{|c|}{ DV: investments made towards founders of the same gender } \\
\hline & Model 11 & Model 12 & Model 13 & Model 14 \\
\hline \multirow[t]{2}{*}{ Past angel investments made } & $-0.111 * * *$ & $-0.114 * * *$ & $-0.115^{* * *}$ & $-0.112 * * *$ \\
\hline & -0.012 & -0.013 & -0.013 & -0.013 \\
\hline \multirow[t]{2}{*}{ Gender: female } & $-1.038 * * *$ & $-1.039 * * *$ & $-1.043^{* * *}$ & $-0.975 * * *$ \\
\hline & -0.224 & -0.224 & -0.224 & -0.225 \\
\hline \multirow[t]{2}{*}{ Founder education: STEM (dummy) } & -0.044 & -0.048 & -0.047 & -0.043 \\
\hline & -0.064 & -0.064 & -0.064 & -0.064 \\
\hline \multirow[t]{2}{*}{ Founder education: business (dummy) } & 0.056 & 0.06 & 0.066 & 0.075 \\
\hline & -0.072 & -0.072 & -0.072 & -0.072 \\
\hline \multirow[t]{2}{*}{ \# of past companies founded } & -0.019 & -0.021 & -0.022 & -0.022 \\
\hline & -0.018 & -0.018 & -0.018 & -0.018 \\
\hline \multirow[t]{2}{*}{ Past companies founded: IPOs } & 0.035 & 0.027 & 0.039 & 0.05 \\
\hline & -0.099 & -0.099 & -0.099 & -0.099 \\
\hline \multirow[t]{2}{*}{ Past companies founded: acquisitions } & $0.129 *$ & $0.127 *$ & $0.131^{*}$ & $0.128^{*}$ \\
\hline & -0.052 & -0.051 & -0.052 & -0.051 \\
\hline \multirow[t]{2}{*}{ Individual investors: IPOs (orthogonalized) } & $0.061^{*}$ & $0.058 *$ & $0.058^{*}$ & $0.061 *$ \\
\hline & -0.028 & -0.028 & -0.028 & -0.028 \\
\hline \multirow[t]{2}{*}{ Individual investors: acquisitions (orthogonalized) } & 0.023 & 0.021 & 0.019 & 0.018 \\
\hline & -0.03 & -0.03 & -0.03 & -0.029 \\
\hline \multirow[t]{2}{*}{ \# of investments by organizations } & & 0.005 & 0.003 & 0.003 \\
\hline & & -0.004 & -0.004 & -0.004 \\
\hline \multirow[t]{2}{*}{ \# of investments by individuals } & & & 0.012 & \\
\hline & & & -0.01 & \\
\hline \multirow[t]{2}{*}{$\begin{array}{l}\text { \# of investments received by angels of the same gender } \\
\text { (orthog.) }\end{array}$} & & & & $0.089 * *$ \\
\hline & & & & -0.029 \\
\hline \multirow[t]{2}{*}{ Constant } & $3.041 * * *$ & $2.997 * * *$ & $3.010 * * *$ & $3.002 * * *$ \\
\hline & -0.561 & -0.553 & -0.564 & -0.557 \\
\hline Observations & 3,779 & 3,779 & 3,779 & 3,779 \\
\hline Number of founders & 926 & 926 & 926 & 926 \\
\hline
\end{tabular}

Standard errors in parentheses

$* * * \mathrm{p}<0.001, * * \mathrm{p}<0.01, * \mathrm{p}<0.05,+\mathrm{p}<0.1$ 
Table 1.7. Panel negative binomial results for investments made towards founders having a school tie with the angel investor.

\begin{tabular}{|c|c|c|c|c|}
\hline \multicolumn{5}{|l|}{ DV: investments made towards founders with school ties } \\
\hline & Model 15 & Model 16 & Model 17 & Model 18 \\
\hline \multirow[t]{2}{*}{ Past angel investments made } & $-0.158 * * *$ & $-0.155^{* * *}$ & $-0.155 * * *$ & $-0.156 * * *$ \\
\hline & -0.017 & -0.017 & -0.017 & -0.017 \\
\hline \multirow[t]{2}{*}{ Gender: female } & -0.092 & -0.088 & -0.088 & -0.088 \\
\hline & -0.237 & -0.238 & -0.238 & -0.238 \\
\hline \multirow[t]{2}{*}{ Founder education: STEM (dummy) } & 0.002 & 0.005 & 0.005 & 0.001 \\
\hline & -0.092 & -0.093 & -0.093 & -0.093 \\
\hline \multirow[t]{2}{*}{ Founder education: business (dummy) } & $0.217^{*}$ & $0.215^{*}$ & $0.216^{*}$ & $0.213 *$ \\
\hline & -0.103 & -0.103 & -0.104 & -0.103 \\
\hline \multirow[t]{2}{*}{ \# of past companies founded } & -0.03 & -0.028 & -0.028 & -0.027 \\
\hline & -0.026 & -0.026 & -0.026 & -0.026 \\
\hline \multirow[t]{2}{*}{ Past companies founded: IPOs } & 0.136 & 0.148 & 0.149 & 0.145 \\
\hline & -0.138 & -0.139 & -0.14 & -0.139 \\
\hline \multirow[t]{2}{*}{ Past companies founded: acquisitions } & 0.095 & 0.096 & 0.096 & 0.099 \\
\hline & -0.076 & -0.076 & -0.076 & -0.076 \\
\hline \multirow[t]{2}{*}{ Individual investors: IPOs (orthogonalized) } & $0.087^{*}$ & $0.090^{*}$ & $0.090 *$ & $0.092 *$ \\
\hline & -0.039 & -0.039 & -0.039 & -0.039 \\
\hline \multirow[t]{2}{*}{ Individual investors: acquisitions (orthogonalized) } & -0.02 & -0.018 & -0.018 & -0.024 \\
\hline & -0.043 & -0.043 & -0.043 & -0.043 \\
\hline \multirow[t]{2}{*}{ \# of investments by organizations } & & -0.005 & -0.005 & -0.005 \\
\hline & & -0.006 & -0.006 & -0.006 \\
\hline \multirow[t]{2}{*}{ \# of investments by individuals } & & & 0 & \\
\hline & & & -0.014 & \\
\hline \multirow[t]{2}{*}{ \# of investments received by angels with school ties (orthog.) } & & & & -0.064 \\
\hline & & & & -0.042 \\
\hline \multirow[t]{2}{*}{ Constant } & $3.171 * *$ & $3.168 * *$ & $3.167 * *$ & $3.192 * *$ \\
\hline & -1.066 & -1.036 & -1.035 & -1.055 \\
\hline Observations & 3,779 & 3,779 & 3,779 & 3,779 \\
\hline Number of id & 926 & 926 & 926 & 926 \\
\hline
\end{tabular}

Standard errors in parentheses

$* * * \mathrm{p}<0.001,{ }^{* *} \mathrm{p}<0.01,{ }^{*} \mathrm{p}<0.05,+\mathrm{p}<0.1$ 
Table 1.8. Panel negative binomial results for investments made towards founders located within the same MSA as the angel investor.

\begin{tabular}{|c|c|c|c|c|}
\hline \multicolumn{5}{|l|}{ DV: investments made towards co-located founders } \\
\hline & Model 19 & Model 20 & Model 21 & Model 22 \\
\hline \multirow[t]{2}{*}{ Past angel investments made } & $-0.161 * * *$ & $-0.161 * * *$ & $-0.160 * * *$ & $-0.162 * * *$ \\
\hline & -0.021 & -0.022 & -0.022 & -0.021 \\
\hline \multirow[t]{2}{*}{ Gender: female } & 0.011 & 0.011 & 0.014 & 0.015 \\
\hline & -0.243 & -0.243 & -0.243 & -0.242 \\
\hline \multirow[t]{2}{*}{ Founder education: STEM (dummy) } & 0.083 & 0.083 & 0.082 & 0.104 \\
\hline & -0.095 & -0.096 & -0.096 & -0.095 \\
\hline \multirow[t]{2}{*}{ Founder education: business (dummy) } & -0.005 & -0.005 & -0.009 & 0.009 \\
\hline & -0.109 & -0.11 & -0.11 & -0.109 \\
\hline \multirow[t]{2}{*}{ \# of past companies founded } & -0.028 & -0.028 & -0.028 & -0.028 \\
\hline & -0.028 & -0.028 & -0.028 & -0.028 \\
\hline \multirow[t]{2}{*}{ Past companies founded: IPOs } & -0.151 & -0.151 & -0.158 & -0.143 \\
\hline & -0.168 & -0.168 & -0.169 & -0.167 \\
\hline \multirow[t]{2}{*}{ Past companies founded: acquisitions } & 0.036 & 0.036 & 0.033 & 0.057 \\
\hline & -0.081 & -0.081 & -0.082 & -0.081 \\
\hline \multirow[t]{2}{*}{ Individual investors: IPOs (orthogonalized) } & 0.042 & 0.042 & 0.043 & 0.031 \\
\hline & -0.043 & -0.044 & -0.044 & -0.044 \\
\hline \multirow[t]{2}{*}{ Individual investors: acquisitions (orthogonalized) } & 0.028 & 0.028 & 0.029 & 0.023 \\
\hline & -0.043 & -0.044 & -0.044 & -0.043 \\
\hline \multirow[t]{2}{*}{ \# of investments by organizations } & & 0 & 0.001 & -0.003 \\
\hline & & -0.006 & -0.007 & -0.007 \\
\hline \multirow[t]{2}{*}{ \# of investments by individuals } & & & -0.007 & \\
\hline & & & -0.015 & \\
\hline \multirow[t]{2}{*}{ \# of investments received by co-located angels (orthog.) } & & & & $0.103 * *$ \\
\hline & & & & -0.038 \\
\hline \multirow[t]{2}{*}{ Constant } & $3.412+$ & $3.411+$ & $3.346^{*}$ & 3.783 \\
\hline & -1.801 & -1.801 & -1.682 & -2.524 \\
\hline Observations & 3,779 & 3,779 & 3,779 & 3,779 \\
\hline Number of founders & 926 & 926 & 926 & 926 \\
\hline
\end{tabular}

Standard errors in parentheses

$* * * \mathrm{p}<0.001,{ }^{* *} \mathrm{p}<0.01,{ }^{*} \mathrm{p}<0.05,+\mathrm{p}<0.1$ 
Table 1.9. Panel negative binomial results for investments made under the three homophily conditions, with MSA dummies.

\begin{tabular}{|c|c|c|c|}
\hline $\begin{array}{l}\text { DV: number of angel investments made } \\
\text { under conditions of homophily }\end{array}$ & $\begin{array}{l}\text { School ties } \\
\text { Model } 23\end{array}$ & $\begin{array}{c}\text { Co- } \\
\text { location } \\
\text { Model } 24\end{array}$ & $\begin{array}{l}\text { Same } \\
\text { gender } \\
\text { Model } 25\end{array}$ \\
\hline \multirow[t]{2}{*}{ Past angel investments made } & $-0.157 * * *$ & $-0.147 * * *$ & $-0.113 * * *$ \\
\hline & -0.017 & -0.022 & -0.012 \\
\hline \multirow[t]{2}{*}{ Gender: female } & -0.189 & -0.007 & $-1.049 * * *$ \\
\hline & -0.238 & -0.232 & -0.224 \\
\hline \multirow[t]{2}{*}{ Founder education: STEM (dummy) } & -0.02 & -0.043 & -0.052 \\
\hline & -0.095 & -0.094 & -0.065 \\
\hline \multirow[t]{2}{*}{ Founder education: business (dummy) } & $0.283 * *$ & 0.068 & 0.109 \\
\hline & -0.105 & -0.106 & -0.073 \\
\hline \multirow[t]{2}{*}{ \# of past companies founded } & -0.022 & -0.02 & -0.016 \\
\hline & -0.026 & -0.027 & -0.018 \\
\hline \multirow[t]{2}{*}{ Past companies founded: IPOs } & 0.169 & -0.166 & 0.045 \\
\hline & -0.142 & -0.166 & -0.101 \\
\hline \multirow[t]{2}{*}{ Past companies founded: acquisitions } & 0.095 & -0.019 & $0.124 *$ \\
\hline & -0.076 & -0.08 & -0.051 \\
\hline \multirow[t]{2}{*}{ Individual investors: IPOs (orthogonalized) } & $0.094 *$ & 0.064 & $0.065^{*}$ \\
\hline & -0.04 & -0.042 & -0.028 \\
\hline \multirow[t]{2}{*}{ Individual investors: acquisitions (orthogonalized) } & -0.018 & 0.003 & 0.017 \\
\hline & -0.043 & -0.041 & -0.029 \\
\hline \multirow[t]{2}{*}{ \# of investments by organizations } & -0.005 & -0.005 & 0.003 \\
\hline & -0.006 & -0.006 & -0.004 \\
\hline MSA dummies & Yes & Yes & Yes \\
\hline \multirow[t]{2}{*}{ \# of investments received by angels with school ties (orthog.) } & -0.06 & & \\
\hline & -0.042 & & \\
\hline \multirow[t]{2}{*}{ \# of investments received by co-located angels (orthog.) } & & $0.069^{*}$ & \\
\hline & & -0.034 & \\
\hline \multirow[t]{2}{*}{ \# of investments received by angels of the same gender (orthog.) } & & & $0.080^{* *}$ \\
\hline & & & -0.029 \\
\hline \multirow[t]{2}{*}{ Constant } & $2.864^{*}$ & $2.751+$ & $2.839^{* *}$ \\
\hline & -1.406 & -1.629 & -0.941 \\
\hline Observations & 3,779 & 3,779 & 3,779 \\
\hline Number of founders & 926 & 926 & 926 \\
\hline
\end{tabular}

Standard errors in parentheses

$* * * \mathrm{p}<0.001, * * \mathrm{p}<0.01, * \mathrm{p}<0.05,+\mathrm{p}<0.1$ 


\title{
CHAPTER II
}

\section{What Makes You Fly: Explaining Entrepreneurs' Success in Angel Investing}

\author{
(co-authored with Dan J. Wang)
}

\begin{abstract}
Angel investors play a crucial role in entrepreneurial ecosystems, providing entrepreneurs and young ventures not just with capital at an early stage, but also with advice and mentorship. While angel investors hail from different walks of life, most angel investors appear to be current or former entrepreneurs. Prevailing wisdom in the ecosystem holds that entrepreneurs are uniquely positioned to do well as investors, in that they possess tacit knowledge not just about their industry, but about the working mechanisms of venture financing, as well. In this paper, we thus examine the question of what drives entrepreneurs' success in angel investing. We do so by leveraging a sample of U.S. angel investors with entrepreneurial experience drawn from CrunchBase and linking their investment performance to their track record as entrepreneurs. We show that while investing across market categories is associated with a higher number of successful exits in general, angel investors with broad entrepreneurial experience are found to do especially well. Success is also a function of effective knowledge translation: on average, successful entrepreneurs tend to become more successful angels, but we find this effect to be stronger the greater the overlap between the entrepreneurial experience of the founder and their angel investment portfolio. We discuss the implications of our findings for research on entrepreneurial ecosystems.
\end{abstract}

This research was funded in part by the Ewing Marion Kauffman Foundation. The contents of this publication are solely the responsibility of the authors.

Keywords: angel investing; performance; 
In the past few decades, entrepreneurship research has increasingly recognized that individuals within entrepreneurial ecosystem move from position to position, and from role to role, in a rather fluid fashion (Burton et al., 2016; Dobrev \& Barnett, 2005; Rider, Thompson, Kacperczyk, \& Tåg, 2016). Indeed, not only do entrepreneurs often come from the private sector, often returning to it as employees at a later date; rather, individuals often move between being employees, founders, board members, and investors, often taking up multiple roles at once. Such role transitions, however, typically require a reconfiguration of knowledge (Powell \& Snellman, 2004), which comes with a redeployment of skills and talents. In the process, lessons learned through past experiences are transformed and adapted to new tasks, which likely poses different challenges to individuals with different professional profiles. Specialists with a narrow skillset might find adaptation to new roles more difficult, while those with a broader, less focused profile might find it easier. But how do individuals build on their experiences in previous roles as they take up new ones? And is having a focused profile (e.g. Ferguson \& Hasan, 2013; Leung, 2014; Merluzzi \& Phillips, 2015) detrimental or helpful to individuals looking to progress in their careers?

Overall, the existing literature does not yet offer a comprehensive account of how success in one role might correlate to later success in other roles. Much in the same fashion, we also know little about whether and how specialization, vis-à-vis maintaining a generalist profile, might help or hinder career outcomes as individuals move from one career step to the next and transition across different roles. These issues are especially germane in the case of entrepreneurship ecosystems, given that in them: 1) individuals often occupy multiple different roles over the course of their careers, such as entrepreneur, employee and investor; and 2) generalist profiles often coexist with highly specialized profiles. We argue, therefore, that a deeper understanding of such issues is very much desirable, and this will serve as the driving force behind our work. 
In this paper, we thus bridge existing accounts of careers, learning, and knowledge translation in market settings to examine entrepreneurial career dynamics (Burton et al., 2016) that is, how individuals transition into, out of, and across roles in the entrepreneurial ecosystem. Extant studies in this area have predominantly focused on entrepreneurial entry from the workforce, as well as on the transition from the workforce to entrepreneurship (Rider et al., 2016; Sørensen \& Sharkey, 2014) and from venture capital to entrepreneurship (Kacperczyk, 2013). Here, however, our focus is on the transition between entrepreneurship and angel investing, which—while highly prevalent—-has been largely overlooked in extant research (although see Cumming et al., 2016 for a notable exception). In so doing, we examine the correlates of successful angel investing outcomes, with an eye to the extent to which successful entrepreneurs-turnedangels leverage their past experience as founders, and whether specialization in either domain is beneficial. In other words, is entrepreneurial experience predictive of success in angel investing? Does specialization as entrepreneurs improve or diminish angel investing performance? At a baseline level, our findings suggest that entrepreneurs-turned-angels whose investing portfolio span market categories tend to do better on average. We argue, however, that the extent of this effect is contingent on the individual's breadth of entrepreneurial experience, inasmuch as those angels who founded companies spanning market categories should reap greater benefits from having a diversified investment portfolio. This is because such angels should be better able to translate their lived experiences as boundary-spanning entrepreneurs into actionable knowledge that will allow them to more effectively invest across market categories. We also argue that successful entrepreneurs should—ceteris paribus—also be more successful angel investors, but that this effect is contingent on the degree of overlap between their entrepreneurial experience and their portfolio choices as investors. 
In what follows, we briefly outline our empirical setting — angel investing — and its role and function in the entrepreneurial ecosystem, as well as its importance for the financing of new ventures. Then, we lay out our theoretical framework and we develop formal hypotheses to be tested concerning the impact of entrepreneurial experience and specialization on angel investing outcomes. We continue by presenting our data, methods, and results, and we conclude by elaborating their implications for the scholarly understanding of the entrepreneurial ecosystem, as well as for the literatures on careers, learning, and specialist/generalist dynamics in management and organizational studies.

\section{ANGEL INVESTING IN THE ENTREPRENEURIAL ECOSYSTEM}

Within the entrepreneurship literature, venture financing represents one of the most extensively investigated topics (Shane \& Cable, 2002; Sorenson \& Stuart, 2001, 2008b), inasmuch as the first milestone for any successful venture consists of securing an adequate supply of capital. Therefore, the capital allocation mechanisms through which ventures are funded is of interest not only to entrepreneurship researchers, but also to economic sociologists (Podolny, 2001) and finance scholars (Hsu, 2004). Most of the existing studies of venture financing have predominantly focused

on venture capital (VC) - that is, private equity funds that specialize in financing small, emerging firms with high growth potential. This literature has yielded numerous useful insights on the structure of venture financing networks, on syndication patterns among venture capital firms, and on the effects that such dynamics may exert on the founding, growth and success of new ventures, as well as on regional dynamics such as the formation of clusters (see for instance Hochberg, Lindsey, \& Westerfield, 2015; Hochberg, Ljungqvist, \& Lu, 2007; Kogut, Urso, \& Walker, 2007; Sorenson \& Stuart, 2001, 2008b). 
Venture capital, however, is only one of the manifold ways in which entrepreneurial ventures can obtain financing (Shane, 2008). In particular, while venture capitalists typically provide the lion's share of the funding for many successful ventures, angel investors fulfill an equally critical, although underappreciated, role. According to Shane (2008: 14), "an angel investor is a person who provides capital, in the form of debt or equity, from his own funds to a private business owned and operated by someone else, who is neither a friend nor a family member." In this regard, angel investors differ from venture capitalists, who typically do not invest their own money, and from friends-and-family investors, who provide capital to business run by family or other acquaintances. Angel investing has grown in both visibility and importance in the past decade, both in the United States and in other nations, developed and developing alike (Kerr et al., 2014), partly thanks to popular TV shows such as Shark Tank, Money Tigers and Dragons' Den. While the size of the angel market is difficult to estimate due to the lack of official figures, in the United States it was believed to be as big as the venture capital market in 2004: indeed, based on official figures business angels invested \$23 billion in young companies, while venture capitalists invested about $\$ 20$ billion. In 2014, after the global financial crisis, the total U.S. angel market was estimated to be worth $\$ 24.1$ billion. In the past few years, angel investing has shown strong growth trends all over the world, with the European angel market doubling in size and the Canadian one tripling. Moreover, interestingly enough, in the United States, a majority of angel investors are current or former entrepreneurs (Shane, 2008); while some angels have backgrounds in consulting, investment banking or large firms more generally, entrepreneurship is by far the most common career path leading to angel investing.

Beyond market size figures, however, angel investors are arguably also important because of the role they have come to play in the entrepreneurial ecosystem. Because most angels invest 
relatively early, at the seed stage, angels are often the very first filter entrepreneurs encounter as they attempt to develop their ideas into successful ventures. Typically, angels come in after entrepreneurs have secured funding from friends and family and have tapped into personal funds, but before venture capital funds get on board. Although the size of the average angel investment is modest, with $\$ 25,000$ being a fairly typical figure, securing angel funding is increasingly seen as a crucial step insofar as the involvement of angel investors, especially prominent ones, is seen as a positive signal (Spence, 1974) by venture capitalists, who tend to look at angel-backed ventures more favorably. Kerr et al., (2014) also found that angel-backed ventures tend to do better than comparable ventures which are not angel-backed, not just because of the angels' venture picking skills and the signaling dynamics described above, but also because angels often provide guidance and mentorship to founders, which can make a difference in the long run.

Additionally, angel investors are —or should be—of particular interest to scholars of organizations and markets because they often make investment decisions based on "gut feeling" (Huang \& Pearce, 2015), since they invest at the early stage when the value of an entrepreneurial idea or the founding team is still largely unknown. Because little information is available, angel investors then rely on their social connections to reduce uncertainty, which makes them particularly prone to being influenced by social considerations. While this line of argument applies to venture capital as well, to a degree (e.g. Podolny, 2001; Sorenson \& Stuart, 2001), the structured, informal nature of angel investing and its reliance on social interaction make it uniquely suitable for analysis through the theoretical lens of economic sociology.

\section{THEORETICAL FRAMEWORK}


In what follows, we articulate our arguments about the potential antecedents of success in angel investing. We integrate various strands of the organizational literature with the goal of providing a comprehensive framework of how entrepreneurs-turned-angels rely on their background as founders to develop portfolio strategies. Our starting point here is that, across organizational domains, the specialist-generalist dilemma represents one of the most intriguing puzzles of the management and entrepreneurship literature. In existing studies on labor markets and careers, scholars have long maintained that specialization is typically advantageous (Ferguson \& Hasan, 2013), in that it allows for an easier assessment of fit by employers, which makes the hiring process smoother. A complementary, skill-based argument advanced by economists (e.g. Becker \& Murphy, 1992: 1137) suggests that specialization is beneficial "because returns to the time spent on tasks are usually greater to workers who concentrate on a narrower range of skills". This line of argument also resonates with Durkheim (1997 [1893]) and Smith (1904), both of whom remarked that the division of labor positively correlates with societal advancement, because it increases as a society progresses and brings about increases in productivity.

Conversely, other scholarly accounts posit that be a generalist might be just as-if not more-advantageous under certain circumstances. For instance Smith (1904), while identifying specialization as a hallmark of societal progress, was perhaps also the first to note that:

...the man whose whole life is spent in performing a few simple operations, of which the effects are perhaps always the same, or very nearly the same, has no occasion to exert his understanding or to exercise his invention in finding out expedients for removing difficulties which never occur. He naturally loses, therefore, the habit of such exertion, and generally becomes as stupid and ignorant as it is possible for a human creature to become. 
Later scholars have noted that generalists might be especially prized in settings where a diversity of experiences and skills is valued (Custódio, Ferreira, \& Matos, 2013). In this regard, and with specific reference to entrepreneurship, Lazear $(2004,2005)$ has advanced a (now dominant) theory of the entrepreneur as jack-of-all-trades, whereby individuals with a balanced skillset are more likely to become entrepreneurs and to succeed at founding new ventures. Conversely, individuals with specialized skill profiles are posited to do better in the labor market (see also Åstebro \& Thompson, 2011).

Given the totality of the arguments presented above, in the context of angel investing outcomes we would expect generalists to do better than specialists for two reasons: 1) not unlike entrepreneurs, angel investors must also build on a diverse skillset and on a breadth of diverse knowledge to be successful, which makes Lazear's theory comparatively more applicable than specialization- or fit-based arguments. If this is the case, then investing across market categories should be associated with better angel investment outcomes. More formally, then:

Hypothesis 1. Market breadth, defined as investing across multiple market categories, will be associated with better angel investing outcomes.

Having established this baseline prediction, we now turn to the broad question of how angel investors can leverage their entrepreneurial experience, and of whether the characteristics of their entrepreneurial background might have a bearing on their investing outcomes. In organizational studies and entrepreneurship alike, a substantial theoretical tradition has maintained that experts tend to make better evaluators than non-experts, effectively acting as gatekeepers to key resources 
and shaping demand (Gans, 2008; Reinstein \& Snyder, 2005). ${ }^{20}$ The entrepreneurial ecosystem is certainly no exception (Ferrary \& Granovetter, 2009), insofar as venture capitalists and angels are recognized as experts and their judgment effectively shapes the supply of capital that new ventures receive. A question that has never been explicitly investigated in the literature, however, is whether expertise accumulated as an entrepreneur might help an investor make better decisions. The question is made even more relevant, we argue, by the fact that in entrepreneurial ecosystem, founders are routinely believed to make better angel investors, regardless of their actual track record.

Here, we thus argue that whether angel investors are able to tap into their own entrepreneurial background to make better investing decisions will be a function of whether they are able to successfully translate knowledge across domains-in this specific case, through different roles in the entrepreneurial ecosystem (Bidwell \& Briscoe, 2010; O’Mahony \& Bechky, 2006). In this regard, research on learning in psychology (Ellis, 1965; Estes, 1970) suggests that individuals' abilities are crucially shaped by their past experiences and, more specifically, that their ability to incorporate new experiences and encode them into useful knowledge hinges on the breadth and variety of their background. The recognition and assimilation of new information, therefore, is a function of the individual's prior knowledge (e.g. Cohen \& Levinthal, 1990).

In the specific case of entrepreneurs-turned-angels, we therefore argue that a more diverse entrepreneurial background should be predictive of better angel investing outcomes when investing spans market categories, since the breadth of experiences should translate into the development of flexible, boundary-spanning knowledge (Carlile, 2002, 2004) which, in turn, will help in the formulation of superior investment strategies across industries. More formally:

\footnotetext{
${ }^{20}$ See also Budescu \& Chen, 2015; Greenstein \& Zhu, 2018; Mollick \& Nanda, 2016.
} 
Hypothesis 2. The effect of market breadth on angel investing outcomes will be especially strong for those angel investors with broad entrepreneurial experience-defined as having founded companies that span a greater number of market categories.

Another recurring theme in the vast literature on learning concerns the extent to which social actors are able to learn from success and failure, both at the individual (Deichmann \& Ende, 2014; Ellis \& Davidi, 2005; Ellis, Mendel, \& Nir, 2006) and at the organizational level (Baum \& Dahlin, 2007; Madsen \& Desai, 2010; Muehlfeld, Sahib, \& van Witteloostuijn, 2012). While the scholarly consensus maintains that success and failure translate into qualitatively different types of learning, the literature has also emphasized the powerful role of success in shaping learning outcomes and, by extension, catalyzing the accumulation and the encoding of knowledge.

For instance, in the context of idea generation, Deichmann \& Ende (2014) show that when success is a rare event, it stands out and therefore presents individuals with a much more salient learning opportunity. As a result, the prior experience of success is a stronger correlate of positive outcomes than experiences of failure. Because the entrepreneurial ecosystem is another example of a setting where success is exceedingly rare, it is little wonder that the literature in entrepreneurship has offered similar findings. For instance, Parker (2013) has shown that serial entrepreneurs tend to develop more successful ventures over time, generating a success-breedssuccess dynamic (see also Gompers et al., 2010). Insofar as it is an extremely rare event, success also offers founders unique opportunities for learning, which can then be leveraged in future endeavors, entrepreneurial or otherwise (March et al., 1991). 
While the above findings pertain to serial entrepreneurship - that is, to entrepreneurs founding several ventures-from the extant literature, it is less clear whether successful experiences have an impact beyond the current role occupied by the individual. Does venture success help individuals who transition from entrepreneurship to the provision of capital, for instance by becoming venture capitalists or angel investors? This question ultimately rests on the portability of knowledge (Groysberg, Lee, \& Nanda, 2008) across different roles in the entrepreneurial ecosystem. For angel investors, success crucially hinges on early-stage identification of companies that will grow to be successful, and that will therefore either be acquired or go public, ideally within a decade. And a successful entrepreneur is likely better able to identify such companies based on his or her own personal experience, having accumulated tacit knowledge not only about the dynamics of a specific industry but, most importantly, about how ventures are run and financed, about what it takes to build a successful founding team, and about how ventures should be scaled to achieve profitability and growth. All of the above types of knowledge are arguably quite helpful to angel investors, as well. For what pertains to our study, it is therefore reasonable to expect that, other things being equal, successful entrepreneurs will be more likely to also succeed at angel investing, insofar as learning from successful experiences will result in superior outcomes as individuals move from entrepreneurship to angel investing and become suppliers of capital. Then:

Hypothesis 3. Entrepreneurial success—defined as having founded companies that were acquired or had an IPO — is associated with better angel investing outcomes. 
Finally, we investigate the boundary conditions of the above hypothesis, looking into whether entrepreneurial success is more predictive of success in angel investing in certain conditions. In this regard, insofar as success in angel investing rests on successful knowledge translation of the "lessons learned" during one's entrepreneurial career, the effect of entrepreneurial success should be moderated by the similarity between an individual's investing activities and their founding experiences. Indeed, when successful entrepreneurs become angels and invest in the same industries in which they founded their own ventures, their experience should be immediately relevant to the task at hand and therefore easier to encode into useful knowledge, which should allow for a more successful portfolio selection. If this is the case, then entrepreneurial success should show a stronger association with angel investing outcomes under conditions of greater overlap between an individual's portfolio companies and their experience as founders. Thus:

Hypothesis 4. The effect of entrepreneurial success on angel investing outcomes will be especially strong for those angel investors with greater overlap between entrepreneurial and investing experience-defined as the number of categories in common between founded companies and investment targets.

\section{DATA AND METHODS}

Our study's main data source, Crunchbase, is a crowdsourced yet curated online database of the startup ecosystem launched in 2007 as an offshoot of TechCrunch, a preeminent online news source for entrepreneurship-related information in the United States. Crunchbase relies primarily on crowdsourcing for contributions, meaning that verified users can input information; however, to ensure data quality and accuracy, such contributions are then typically verified and triangulated with other comparable databases (such as AngelList) as well as with commercial data sources (like 
VentureSource and VentureXpert) by Crunchbase staff. Because Crunchbase provides limited information about individual founders and investors, however, we also use other sourcesprimarily LinkedIn and U.S. Census data - to assign individuals to a geographical area, operationalized as the relevant Metropolitan Statistical Area (MSA).

Dependent variable. Because we focus on success in angel investing as our dependent variable, and because success in angel investing is conventionally measured as the number of successful exits - that is, either acquisitions or initial public offerings (IPOs) - within an angel investor's portfolio, we measure success as the logged count of successful exits, where a successful exit is defined to occur when a company in an angel investor's portfolio gets acquired or goes public. While IPOs typically tend to result in a much higher payoff than acquisitions, Crunchbase typically does not include information about the dollar value of deals, so we are unable to incorporate this information into our analysis. In our view, however, it makes sense to consider acquisitions and IPOs together in this setting, insofar as: 1) successful exits constitute a very small portion of the typical investor's portfolio, and therefore they are both seen as extremely positive outcomes; 2) IPOs are exceedingly rare events in the angel investing world, and thus it makes little sense to consider them separately.

Independent variables. For Hypothesis 1, the relevant independent variable is portfolio breadth, operationalized as the number of Crunchbase categories represented in the focal angel investor's current portfolio. ${ }^{21}$ Because every company in Crunchbase is assigned one or more categories, we construct this variable by simply adding up the number of unique categories for all companies in the focal angel investor's portfolio at time $t$. In a similar fashion, for Hypothesis 2

\footnotetext{
${ }^{21}$ Crunchbase provides a two-level categorization system, with categories and higher-order category groups. Here we use category groups because Crunchbase includes over 700 categories, and therefore using these would make comparison across firms doing very similar things extremely difficult.
} 
the breadth of entrepreneurial experience is defined as the number of unique categories assigned to all companies founded by the angel investor up to time $t$. As far as Hypothesis 3 is concerned, and consistent with our dependent variable, we operationalize entrepreneurial success as the number of successful exits recorded for companies founded by the focal entrepreneur-turnedangel. Finally, for Hypothesis 4 the degree of overlap between founding and portfolio categories is operationalized as:

$$
D O O=\frac{|P \cap F|}{|P \cup F|}
$$

where $P$ are the unique categories in the angel investor's portfolio at time $t$ and $F$ are the unique categories spanned by the companies founded by the same individual up to time $t$. This variable varies between 0 , in the case in which the individuals' angel investing activity is completely unrelated to their founding experience, and 1 in the case in which there is complete overlap.

Control variables. To help rule out potentially confounding alternative explanations, we add a battery of control variables to our models. Consistent with prior literature, we control for the gender of the entrepreneur-angel, because of the substantial barriers faced by women and the differential treatment they typically receive in the ecosystem (e.g. Brooks, Huang, Kearney, \& Murray, 2014; Kanze, Conley, Huang, \& Higgins, 2017), which might result in different outcomes. Because more experienced angel investors might be more skilled at picking successful ventures, we also control for angel investor tenure - that is, the number of years from the first angel investment made by the individual—as well as for the number of past angel investments made. Because the more prolific serial entrepreneurs might also be better angel investors, we also control for the number of companies founded by the individual. Finally, to rule out unobserved heterogeneity at the geographic level, as well as time effects, our models also include year 
dummies and Metropolitan Statistical Area (MSA) dummies. Table 1 reports descriptive statistics for all of our variables, as well as a correlation table.

Insert Table 2.1 about here

\section{RESULTS}

Insert Table 2.2 about here

Table 2 reports the results of the panel OLS models we used to test our hypotheses. Model 1 includes just the basic control variables, while Model 2 adds dummies for the Metropolitan Statistical Area (MSA) where the angel investor is based, as well as year dummies. Model 3 then adds market breadth, i.e. the number of categories spanned by the investment portfolio of the focal angel investor in year $t$. Its coefficient is positive and significant, as predicted, which is consistent with Hypothesis 1 and reflective of the idea that diversification across sectors tends to yield better angel investing outcomes. Model 4 then adds the interaction between market breadth and the breadth of entrepreneurial experience - that is, the number of categories spanned by the companies founded by the entrepreneur-turned-investor up to time $t$. In line with Hypothesis 2, the coefficient for this interaction term is also positive and significant, corroborating our assertion that angel investors who span market categories in their portfolio do especially well when they also have broad experience as entrepreneurs, insofar as entrepreneurial breadth allows for the more flexible translation of knowledge across domains, resulting in better angel investing outcomes when an investor's portfolio also spans market boundaries. 
Model 5 includes two additional variables: the number of successful exits for companies founded by the focal entrepreneur-angel, whose positive and significant coefficient indicates that more successful entrepreneurs do better at angel investing, and the overlap between the portfolio categories and the founding categories, in line with Hypothesis 3. This coefficient is negative and significant, which is suggestive of the fact that a greater overlap between investing portfolio and entrepreneurial experience in terms of market categories actually worsens investment performance. While this result might appear counterintuitive, it is actually in alignment with the idea that angel investors who rely predominantly on their past experience as entrepreneurs - which is typically limited - in their investment choices tend to do comparatively worse than categoryspanners, in that the latter are able to diversify their portfolio in a more effective manner. Model 6 then interacts these two latter variables to show that the extent to which entrepreneurs are learning from success is, however, a function of overlap between their investment choices and their entrepreneurial choices; in other words, entrepreneurial success translates to angel investing success to a greater degree when the overlap between entrepreneurial and investing choices is greater, which provides support for Hypothesis 4.

\section{DISCUSSION}

In this paper, we have examined the antecedents of successful outcomes in angel investing, which, among all roles individuals can play in the entrepreneurial ecosystem, is perhaps the one having received the least amount of scholarly attention to date. In so doing, we posited that successful angel investing outcomes would be (at least in part) explained by the extent and characteristics of one's experience as founder, as well by having a generalist (vis-à-vis specialist) profile. In this regard our main findings are: 1) that angel investing across industries correlates with superior outcomes, and therefore "generalist" angel investors tend to do comparatively better; 2) that angel 
investors with broad entrepreneurial experience are found to do even better upon investing across market categories; 3) that successful entrepreneurs tend to do better at angel investing; and 4) that the extent to which angels are able to translate their entrepreneurial success into knowledge useful to their angel investing activities is a function of the overlap between their portfolio and their experience as founders.

Overall, beyond contributing to the scholarly understanding of career dynamics in the entrepreneurial ecosystem, it is our contention that our work also has broader implications for several strands of the literature on organizations and labor markets. First of all, our results extend, and build on, Lazear's (2005) conceptualization of the entrepreneur as jack-of-all-trades, showing that a broad, generalist profile is beneficial even as entrepreneurs transition to angel investing because breadth and diversity of experiences help individuals translate their knowledge in a more flexible manner in this setting, as well. Second, our work integrates existing accounts of learning in market settings by empirically investigating the extent to which learning from experiences, especially successful ones, is influenced by the specialization of an individual's skillset, as well as by the degree of matching between current tasks and past experiences. And finally, our paper also contributes to the burgeoning literature on role transitions in entrepreneurial ecosystem (Burton et al., 2016; Rider et al., 2016; Sørensen \& Sharkey, 2014) by examining the career trajectories of entrepreneurs-turned-angels, which account for a majority of the informal supply of venture financing in the U.S. today. In pursuing this line of inquiry, our hope is to draw greater scholarly attention to issues concerning transitions among different roles in the ecosystem, as well as to the challenges that such transitions entail in terms of knowledge translation and skill adaptation, as well as to the contingent benefits of specialization in such circumstances. 
Table 2.1. Descriptive statistics and correlation table.

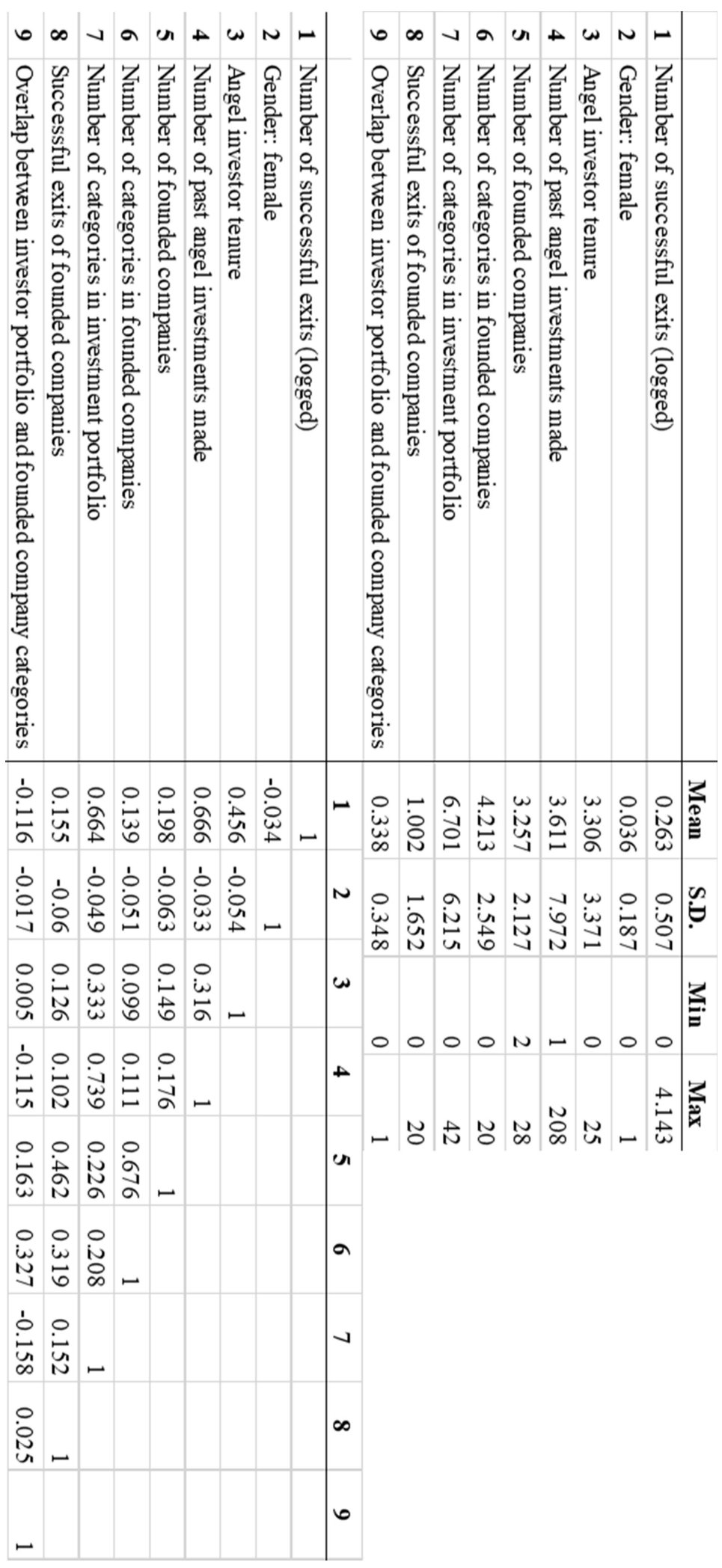


Table 2.2. Panel OLS models for the number of successful exits in the focal angel investors portfolio.

\begin{tabular}{|c|c|c|c|c|c|c|}
\hline $\begin{array}{l}\text { DV: logged cumulative count of successful exits for the focal angel } \\
\text { investor }\end{array}$ & (1) & (2) & (3) & (4) & (5) & (6) \\
\hline VARIABLES & Model 1 & Model 2 & Model 3 & Model 4 & Model 5 & Model 6 \\
\hline \multirow[t]{2}{*}{ Gender: female } & 0.005 & -0.004 & 0.012 & 0.006 & 0.010 & 0.009 \\
\hline & $(0.021)$ & $(0.022)$ & $(0.021)$ & $(0.021)$ & $(0.021)$ & $(0.022)$ \\
\hline \multirow[t]{2}{*}{ Angel investor tenure } & $0.050 * * *$ & $0.050 * * *$ & $0.042 * * *$ & $0.042 * * *$ & $0.042 * * *$ & $0.041^{* * *}$ \\
\hline & $(0.003)$ & $(0.003)$ & $(0.003)$ & $(0.003)$ & $(0.003)$ & $(0.003)$ \\
\hline \multirow[t]{2}{*}{ Number of past angel investments made } & $0.032 * * *$ & $0.032 * * *$ & $0.022 * * *$ & $0.022 * * *$ & $0.022 * * *$ & $0.022 * * *$ \\
\hline & $(0.004)$ & $(0.004)$ & $(0.003)$ & $(0.003)$ & $(0.003)$ & $(0.003)$ \\
\hline \multirow[t]{3}{*}{ Number of founded companies } & $0.014 *$ & $0.016^{* *}$ & $0.014^{* *}$ & $0.011^{*}$ & 0.007 & 0.006 \\
\hline & $(0.006)$ & $(0.006)$ & $(0.005)$ & $(0.005)$ & $(0.005)$ & $(0.005)$ \\
\hline & & & & - & - & - \\
\hline \multirow[t]{2}{*}{ Number of categories in founded companies } & 0.003 & 0.001 & -0.005 & $0.019^{* * *}$ & $0.016^{* * *}$ & $0.017 * * *$ \\
\hline & $(0.003)$ & $(0.003)$ & $(0.003)$ & $(0.004)$ & $(0.004)$ & $(0.004)$ \\
\hline \multirow[t]{2}{*}{ Number of categories in investment portfolio } & & & $0.023 * * *$ & $0.015^{* * *}$ & $0.014 * * *$ & $0.014 * * *$ \\
\hline & & & $(0.003)$ & $(0.003)$ & $(0.003)$ & $(0.003)$ \\
\hline \multirow[t]{2}{*}{ Categories in founded companies X Categories in investment portfolio } & & & & $0.002 * * *$ & $0.002 * * *$ & $0.002 * * *$ \\
\hline & & & & $(0.000)$ & $(0.000)$ & $(0.000)$ \\
\hline \multirow[t]{3}{*}{ Successful exits of founded companies } & & & & & $0.016^{* * *}$ & 0.004 \\
\hline & & & & & $(0.005)$ & $(0.007)$ \\
\hline & & & & & - & - \\
\hline \multirow[t]{2}{*}{ Overlap between investor portfolio and founded company categories } & & & & & $0.052 * * *$ & $0.077^{* * *}$ \\
\hline & & & & & $(0.013)$ & $(0.014)$ \\
\hline \multirow[t]{2}{*}{ Successful exits X Overlap } & & & & & & $0.034 * *$ \\
\hline & & & & & & $(0.012)$ \\
\hline MSA dummies & No & Yes & Yes & Yes & Yes & Yes \\
\hline \multirow[t]{2}{*}{ Year fixed effects } & No & Yes & Yes & Yes & Yes & Yes \\
\hline & - & & & & & \\
\hline \multirow[t]{2}{*}{ Constant } & $0.079 * * *$ & -0.129 & $-0.159+$ & -0.104 & -0.075 & -0.066 \\
\hline & $(0.014)$ & $(0.136)$ & $(0.084)$ & $(0.096)$ & $(0.088)$ & $(0.084)$ \\
\hline Observations & 11,132 & 10,713 & 10,713 & 10,713 & 10,713 & 10,713 \\
\hline Number of angels in the sample & 2,596 & 2,501 & 2,501 & 2,501 & 2,501 & 2,501 \\
\hline
\end{tabular}

Robust standard errors in parentheses

$* * * \mathrm{p}<0.001,{ }^{* *} \mathrm{p}<0.01,{ }^{*} \mathrm{p}<0.05,+\mathrm{p}<0.1$ 


\title{
CHAPTER III
}

\section{Community Social Capital and the Financing of New Ventures: Evidence from Angel Investing, 2005-2015}

\begin{abstract}
A growing body of literature in entrepreneurship has come to recognize that entrepreneurial ecosystem dynamics are a function, at least in part, of the characteristics the social milieu in which they are embedded. Venture financing, in particular, can be seen a social process, insofar as it requires the development of relationships between one of more investors and the founding team. Here, I advance the argument that social capital at the community level has a bearing on individual decision concerning entry into venture financing, as well as capital allocation choices. This is because both the decision to become an entrepreneur and the eventual, subsequent transition to angel investing are inherently social, and are therefore especially likely to occur in communities that are characterized by greater social connectedness. Furthermore, areas with more welldeveloped opportunity structures for socialization should also be especially conducive to the development of local financing relationships. In this study, I thus examine the role of community social capital in angel investing across Metropolitan Statistical Areas (MSAs) in the United States between 2005 and 2015, building on data from CrunchBase and several U.S. Census datasets. In so doing, I show that: 1) MSAs with greater social capital exhibit a higher density of VC-funded entrepreneurs; 2) in such MSAs, a greater proportion of this population of entrepreneurs will become angel investors; and 3) such areas are also characterized by a comparatively higher proportion of angel investments targeting companies within the same MSA. I then discuss the implications of my findings for the literature on community social capital in sociology, as well as for the broader scholarly understanding of entrepreneurial ecosystems.
\end{abstract}

This research was funded in part by the Ewing Marion Kauffman Foundation. The contents of this publication are solely the responsibility of the author.

Keywords: angel investing; social capital; community 
"Not only is investing locally more convenient, but it is also a way for me to give back and contribute to the New York ecosystem, which has given me so much." 22

One of the centerpieces of the economic sociology literature in the past few decades has been the notion of embeddedness (Granovetter, 1985; Uzzi \& Lancaster, 2004): that is, the idea that patterns of economic exchange are inextricably "embedded" into the social milieu within which they take place. Only recently, however, have entrepreneurship scholars begun to fully grasp the importance of studying the linkages between community-level features and the emergence and growth of new ventures (Dahl \& Sorenson, 2010, 2012). This is not to say that location has not featured prominently in extant research on entrepreneurship and venture financing (Saxenian, 1994). Existing research, however, has focused on agglomeration (e.g. Sorenson \& Audia, 2000) as a source of economies of scale and knowledge diffusion, such as in the case of the Silicon Valley, or of Italy's industrial districts. What remains unclear, however, is whether location matters merely because of its economic climate and the presence of other firms, or there is more to the picture. In this regard, economic geographers have long held that entrepreneurship is also a function of a region's culture, as expressed through its values and its (e.g. Aoyama, 2009; Gertler, 2004). Yet even this explanation is likely incomplete, insofar as empirical studies have failed to identify a strong link between culture and ecosystem-level patterns (Lee, Florida, \& Acs, 2004; Sorenson, 2017).

To address this "undersocialized" view of entrepreneurial ecosystem, recent studies have begun advancing a more explicit connection between entrepreneurial ecosystems and the patterns of social relationships within the communities in which they are embedded. For instance, Kwon, Heflin, \& Ruef (2013) explore the extent to which community social capital affects entrepreneurship, measured as self-employment, while Samila \& Sorenson (2017) found that

\footnotetext{
${ }^{22}$ Excerpt from an interview with a NYC-based angel investor conducted in the Spring of 2017.
} 
venture capital has a more pronounced effect on entrepreneurial growth in communities characterized by greater connectedness and integration. These recent developments, however, have largely overlooked how community characteristics influence the emergence and evolution of venture financing processes. This is an important omission, because whether entrepreneurial ecosystems grow and thrive does not uniquely rest on entrepreneurship as a creating force. Venture financing is equally necessary, but the literature offer little insight concerning what might drive individuals and organizations to become suppliers of capital. In other words, for a thriving ecosystem to develop, founding and funding dynamics are equally important, yet existing work has predominantly focused of the former, at the detriment of the latter. In this study, therefore, my goal is to shed light on these dynamics by exploring how variations in social capital at the Metropolitan Statistical Area (MSA) level and over time affect the local prevalence of entrepreneurs, angel investors, as well as angel financing patterns.

In the remainder of this paper, then, I first discuss the empirical setting for this studyangel investing in the United States — with a view to briefly explaining what it is, how it differs from venture capital, as well as who angel investors are and where they come from. Then, after briefly reviewing the literature on social capital as it pertains to entrepreneurship and venture financing, I build a theoretical framework that links social capital with: a) the number of entrepreneurs at the community-level; b) the number of entrepreneurs that will become angel investors; and c) the extent to which the angel investments made by angels within the community will remain within the community, by financing local ventures. I continue by discussing my data, variables, and methods. After presenting my results, in the concluding section I elaborate on the implications for the literature and I outline directions for future work. 


\section{ANGEL INVESTING IN THE UNITED STATES}

While venture financing has received substantial attention in the scholarly literature on entrepreneurship, most of the studies that have done so have focused on venture capital (e.g. Sorenson \& Stuart, 2001). This is likely a function of both the relative prominence of venture capital, relative to angel investing, in terms of the amount of capital provided to ventures - typical angel investments tend to be between $\$ 20,000$ and $\$ 50,000$, while a round of venture capital often exceeds $\$ 1$ million — and the relative availability of data: while commercial databases for the study of venture capital investment patterns have long been available, such as VentureSource and VentureXpert-historically most empirical studies of angel investing relied on surveys and relatively small samples. Yet this research trend runs counter to the increased importance and visibility of angel investing in the past couple decades, both in the United States and globally (Lerner et al., 2016). In the past few years, the angel investing market has also shown strong growth trends all over the world.

Unlike venture capitalists, who are typically managers who operate a fund specialized in new ventures, angel investors are individuals who provide "capital, in the form of debt or equity, from their own funds to a private business owned and operated by someone else, who is neither a friend nor a family member" (Shane, 2008: 14). Unlike venture capitalists, therefore, angel investors tap into their personal funds, which often translates into a stronger degree of personal involvement in the portfolio of ventures the angel chooses to finance. While a majority of angel investors tend to be clustered in the three largest U.S. ecosystems-New York, the Silicon Valley, and Boston - many, if not most, U.S. communities appear to have an active angel investing scene, including relatively remote areas of the country, like Hawai'i. Furthermore, while a good number 
of angels have backgrounds in the corporate sector-such as banking, finance, or management consulting - in the U.S. a majority of angel investors are current or former entrepreneurs.

The above discussion raises a number of related questions that should be of interest to scholars and practitioners alike: why do angel investors decide to provide funding to entrepreneurs and their nascent ventures? And why do so many entrepreneurs choose this path? While collecting my dissertation data I had the opportunity to speak with a variety of angel investors, and therefore I also had a chance to inquire about their motivations. A good starting point here, however, is the conventional wisdom suggesting that the economic motive is the dominant force; that is, most angel investors decide to fund nascent ventures primarily to make money. This is consistent with the limited empirical evidence available: for instance, a survey of 230 business angels in Germany (Stedler \& Peters, 2003) finds support for the idea that the desire to earn money and achieve superior returns is a significant motivator for angels, insofar as it is generally listed among the top four reasons for investing.

This basic intuition, however, runs counter to what are known to be the overall returns for the U.S. population of angel investors (Mason \& Harrison, 2002). Among suppliers of capital, the fact that angel investors on average do not make much money and that the returns to angel investing tend to be lower than those of venture capital are common knowledge: this is both because the returns to venture capital have not been stellar in the past two decades (Mulcahy, Weeks, \& Bradley, 2012) and because angels tend to invest much earlier than VCs do, which often results in higher risk and less compelling opportunities being available. ${ }^{23}$ For instance, in a study of financial returns of angels who invest in groups, Wiltbank \& Boeker (2007) found that 52 percent of investments lose money (i.e. produces a return of less than 1X); on the other hand, 61

\footnotetext{
${ }^{23}$ See for example: https://techcrunch.com/2012/09/30/why-angel-investors-dont-make-money-and-advice-forpeople-who-are-going-to-become-angels-anyway/
} 
percent of investors sampled had an overall portfolio return greater than $1 \mathrm{X}$. Similar patterns were observed by Wiltbank \& Brooks (2016), which in a later study of angel returns found that: 1) the median angel investment is a loss; 2) the earning distribution is highly skewed, so that 10 percent of exits generate 85 percent of all returns; and 3) 70 percent of all investments lose money. All of the above is not to say that angel investing does not make money in the absolute: Wiltbank \& Brooks' (2016) data suggests that the internal rate of return for angel investment portfolios is 22 percent. However, earnings are likely to be unevenly distributed across the population, with the greatest returns accruing to a fairly small subset of wealthy, well-connected, and powerful investors. This leaves open the question of what might lead the remaining angel investors to choose finance new ventures, insofar as they are statistically unlikely to achieve substantial returns, especially in light of the available alternatives, such as the stock market or real estate.

To partly address this question, in the first chapter of this dissertation I sketched a sociological explanation of entry by entrepreneurs into angel investing; in so doing, I suggested that generalized reciprocity and homophily play a role, in that entrepreneurs who are financed by angels are especially likely to become angels in turn, and even more so when they are similar to the financing angel across one or more dimensions. Further, I argued that these mechanisms' influence extends to the entrepreneurs-turned-angel's investing choices and push them to invest in other entrepreneurs who are also like them. In the remainder of the paper, I extend this line of inquiry by presenting a similar, and in many ways complementary, argument: that the level of social connectedness within a community—traditionally labeled "social capital"—has a bearing not just on entrepreneurial entry (Kwon et al., 2013), but also on venture financing choices, and specifically as they pertain to angel investing. I elaborate on these ideas in extended form below. 


\section{THEORETICAL FRAMEWORK}

Social capital in the literature: organizational studies vs. sociology. Over the past few decades, the construct of social capital has been the subject of a burgeoning amount of research efforts, both in management (e.g. Adler \& Kwon, 2002; Kwon \& Adler, 2014) and in sociology (e.g. Portes, 1998; Portes \& Vickstrom, 2011). As far as the former strand of the literature is concerned, business scholars have predominantly focused on social capital as a strategic resource that individuals and organizations can exploit in market settings, with the core intuition being that the focal actor's relations - whether based in economic exchange, hierarchy, or pure socialization (Adler \& Kwon, 2002) — can be leveraged to produce positive outcomes of various kinds. In the extant literature, these have included — but are not limited to - career outcomes (Burt, 1992), hiring (Fernandez, Castilla, \& Moore, 2000), job search (Granovetter, 1973), knowledge transmission (Hansen, 1999), learning (Kraatz, 1998), and value creation (Tsai \& Ghoshal, 1998). Overall, this literature has emphasized the role of social capital as a strategic resource: that is, as a set of relational assets that can be leveraged in the pursuit of specific opportunities and goals. This general orientation is reflected in, and extends to, studies of entrepreneurship carried out by management scholars: existing work has examined the role of relationships, such as the founding team's social ties, in shaping new venture outcomes (Shane \& Cable, 2002); it has also analyzed connections as opportunities for opportunity identification and resource mobilization (Stuart \& Sorenson, 2003) and their role in the emergence of interfirm collaboration (Walker, Kogut, \& Shan, 1997).

While in organization and management studies social capital has typically been explored at the level of the focal social actor, research on social capital in sociology is largely characterized by a community focus - that is, a conceptualization of social capital as a community-level, rather 
than an actor-level, property (Portes, 1998). This builds on earlier sociological conceptualization of social capital as grounded in group relations, such as Bourdieu's (1985: 248), who defined social capital as "the aggregate of actual or potential resources which are linked to possession of a durable network of more or less institutionalized relationships of mutual acquaintance or recognition". In a similar fashion, Coleman (1988: 98) noted that "unlike other forms of capital, social capital inheres in the structure of relations between actors and among actors. It is not lodged either in the actors themselves or in physical implements of production". While different in many respects, the theorizations of social capital offered by Bourdieu and Coleman are brought together by a common focus on networks of social relationships comprising individuals and families, as well as structural features—-such as density—of such networks.

In contrast to the network-oriented approaches described above, in the 1980s and 1990s political scientist Robert Putnam championed an alternative conceptualization whereby social capital is defined as a public good; a community-level feature potentially applicable to entire societies. Social capital is then recast as the collection of "features of social organizations, such as networks, norms, and trust, that facilitate action and cooperation for mutual benefit" (Putnam, 1993: 35). This expanded definition — which, over time, proved to be perhaps the most populargoes beyond social relationships to encompass dimensions of community participation such as "newspaper reading, membership in voluntary associations, and expressions of trust in political authorities" (Portes, 1998: 18). Among the most best studied components of social capital within this literature are ethnic integration (Alesina \& La Ferrara, 2000, 2014), trust (Guiso, Sapienza, \& Zingales, 2008; Knack \& Keefer, 1997), and membership in voluntary associations (e.g. Ruef \& Kwon, 2016). These dimensions underscore the idea that social cohesion rests primarily on the extent to which: a) the community is homogenous, rather than balkanized; b) individuals within 
the community are able to trust each other; and c) individuals are actively engaged in community activities that require social interaction and collaboration.

Entrepreneurship and the community. In parallel with these advancements in the literature on social capital, scholars across disciplines have broadly acknowledged that the underlying social structure of a community can have lasting effect on entrepreneurial patterns, as well as on the growth and evolution of entrepreneurial ecosystems (Westlund \& Bolton, 2003). Indeed, the very notion of an entrepreneurial ecosystem is ultimately that of a complex social, cultural, and material structure, comprising not just entrepreneurs and their ventures, but also educational institutions, investors, funds, as well as specialized organizations such as incubators and accelerators (Spigel, 2015). Arguably, ecosystems rest as much on intangible aspects, such as the relationships between social actors and cultural elements (Aoyama, 2009), as much as they do on economic and technical factors like market openness or physical infrastructure. It is therefore little wonder that the social and cultural milieu of a community often plays an outsize role in determining the entrepreneurial features of local ecosystems.

In this regard, a recent study by Kwon, Heflin, \& Ruef (2013) sheds light on the linkages between community social capital and entrepreneurship, measured as the prevalence of selfemployment. By leveraging multiple archival datasets, such as the General Social Survey (GSS) and the Social Capital Community Benchmark Survey (SCCBS), the authors find that communities characterized by greater social trust have a higher prevalence of entrepreneurship. Furthermore, membership in certain voluntary organizations was also associated with higher entrepreneurship rates at the community level. These findings point to social capital playing a significant role in entrepreneurial choices and, by extension, in shaping the entrepreneurial proclivity of the community. For what pertains to entrepreneurial ecosystems, therefore, my first (baseline) 
hypothesis is that metropolitan areas characterized by greater social capital should also have a higher number of entrepreneurs in their ecosystem, other things being equal. Formally:

Hypothesis 1. MSAs with greater social capital will be characterized by a higher number of (VCbacked) entrepreneurs.

Community and the supply of capital. Considerations similar to the ones made about consumers of capital can be extended to suppliers of capital within the ecosystem - that is, individuals and organizations that choose to invest in new ventures. In this regard, existing studies of venture financing have predominantly focused on venture capital (VC) and the social structure thereof (Hochberg et al., 2015, 2007; Hochberg, Ljungqvist, \& Lu, 2010)-indeed, by now a sizeable literature has emerged to link the network patterns of suppliers of capital with a variety of outcomes including new venture founding, employment, and aggregate income (Samila \& Sorenson, 2011); alliance formation (Lindsey, 2008); patent and product innovation (Pahnke, Katila, \& Eisenhardt, 2015); and the professionalization of start-up companies (Hellmann \& Puri, 2002). What has received notably less attention in this area of inquiry, however, are the antecedents of the supply of capital to young ventures: that is, why do individuals and organizations decide to engage in venture financing, relative to other capital allocation options? And once they do take this step, what kind of ventures do they choose to finance? These questions are important, insofar as they help determine what ventures will get funded and, in turn, the direction in which a given ecosystem will evolve.

In this regard, scholars have only recently begun to investigate the latter question, examining how homophily dynamics (Greenberg \& Mollick, 2017; Kanze et al., 2018) and other 
cognitive biases (Brooks et al., 2014; Huang \& Pearce, 2015) influence decision-making by investors in entrepreneurial finance. The former question, however, concerning how individuals and organizations decide to pursue venture financing opportunities remains largely unexplored, and is therefore ripe for theoretical investigation. In the first chapter of this dissertation, I partially addressed it by looking at the role of generalized reciprocity and homophily in the decision by entrepreneurs to become angel investors. Here, I complement and extend the above line of argument by proposing that, in a similar fashion, social capital will also play a substantial role in the provision of capital, in that it is likely to shape whether individuals choose to pursue angel investing, and if they do, what kind of individuals and ventures they might choose to finance.

A useful starting point for my argument here is provided by Samila \& Sorenson's (2017) study of the complementary role played by community-level social capital and venture capital in shaping outcomes at the ecosystem level. The authors found that communities with a higher degree of interconnectedness - measured here as racial micro-geographical integration-benefitted more from venture capital, as far as innovation, entrepreneurship and economic growth are concerned. This is because social capital, in the form of community integration, creates increased opportunities for social interaction. In turn, enhanced social interaction then results in better mentoring for entrepreneurs, greater circulation of ideas, and improved resource mobilization. Another relevant study is Kwon et al. (2013), which found a positive relationship between community social capital and entrepreneurship, on the grounds that "individuals receive distinct advantages from being embedded in effective brokers — organizations that, both intentionally and unintentionally, connect people to other people, organizations, and their resources" (Small, 2009: 18). The socialization spaces made available by social capital therefore promote entrepreneurship primarily by: 1) putting individuals in contact with a broader and more diverse group of people, 
increasing network diversity and decreasing closure; and 2) enabling knowledge circulation and information transfer, factors which are likely to result in an easier identification of entrepreneurial opportunities.

A common thread between these two studies is that community-level social capitalhowever defined - is associated with enhanced and improved forms of interaction across social barriers such as race, gender, profession, or class, as well as with a greater degree of information circulation. How do these factors relate to the supply of capital, and more specifically to an entrepreneur's decision to pursue it by entering angel investing? My argument is that in communities characterized by greater social capital, entrepreneurs will be exposed to a greater wealth of information about potential new ventures, as well as greater opportunities to socialize with people who either are, or are interested in becoming, entrepreneurs. Because of the brokerageenhancing effect of social capital, therefore, entrepreneurs in such communities should be especially prone to come into contact with new ventures and choose to invest in them. Conversely, in communities that are relatively more fragmented and isolated, entrepreneurs will receive less exposure to other entrepreneurs — both current and potential—and will therefore less inclined to pursue angel investing as a capital allocation strategy, focusing instead on alternative options such as real estate or the stock market. Formally, then:

Hypothesis 2. MSAs with greater social capital will see a higher number of (VC-backed) entrepreneurs become angel investors.

Once entrepreneurs within a community do become angel investors, however, the question of what types of individuals and ventures they will choose to invest in naturally arises. In this 
regard, my third and final argument is that the stronger sense of community identification that social capital fosters should make investing in other entrepreneurs within the community preferable. This is because, ever since Coleman (1988), social capital has been associated with the idea that community members support each other. In a similar fashion, Portes \& Vickstrom (2011: 473) note that one of the characteristics of community social capital is the emergence of organic solidarity, as well as the existence of an "emotional identification that the individual feels with her metropolis", built on "shared values and the recognition of a common normative order required for the fulfillment of individual goals". Under these conditions, individuals are especially likely to identify strongly as members of a given community, to feel a sense of obligation towards it, and to support it in times of need.

But how do these general arguments surrounding community social capital apply to venture financing — if at all—and more specifically to angel investing? Among the manifold reasons why people might choose to become angel investors (see Shane, 2008 for a comprehensive discussion) the desire to give back is often features prominently, as does the decision to "give back" in some way. Many angel investors go as far as framing their activities as acts of responsibility toward the community, or as a way to help individuals realize their true potential. This theme emerged time and time again during the interviews I conducted with angel investors. For example, a leading angel investor in New York City openly expressed a preference for investing in local ventures and stated that doing so was not merely a matter of convenience:

"Not only is investing locally more convenient, but it is also a way for me to give back and contribute to the New York ecosystem, which has given me so much.” 
Another investor, who had started an angel group for alumni of the university he attended as an undergraduate, described how being part of a shared social group can make all the difference when it comes to providing or receiving venture financing:

“...when people are connected by an affinity_alumni groups, for example — they are flat-out more willing to help one another. [...] Somebody who sold a company for a billion dollars is infinitely more likely to serve on a board of a seed company when they share a common bond."

These quotes suggest that embeddedness-or the superimposition of social and economic ties within communities - is a primary driver of investment decisions. If the community in which an investor is embedded is rich in social capital, therefore, I would expect him or her to be especially prone to finance other entrepreneurs in the community-relative to entrepreneurs located elsewhere - because doing so represents a tangible way to give back to the community while at the same time building relationships and contributing to the local ecosystem's growth. Therefore:

Hypothesis 3. MSAs with greater social capital will see a higher number of angel investments targeting companies within the same MSA.

\section{DATA AND METHODS}

Data and methods. The main data source for this study is CrunchBase, a crowdsourced but curated online database of the startup ecosystem, comprising information not just about startups and their founders, but also about investors, funds, incubators, accelerators, and other entities that are also part of the ecosystem. CrunchBase also maintains a record of investments in 
new ventures by individuals and organizations; while venture capital investments are extensively tracked by commercial databases, this is remarkable, insofar as it is - to my knowledge - the first available, large-scale public records of angel investments in the United States. Originally a spinoff of online magazine TechCrunch, over time CrunchBase has grown to be the most comprehensive source for entrepreneurship data currently available (e.g. see Ter Wal, Alexy, Block, \& Sandner, 2016; Wang, Pahnke, \& McDonald, 2015). I used CrunchBase to create a list of founders of startups in the United States within our observation window; that is, between 2005 and 2015. I end my analysis in 2015 because it was the last full year of available data at the time when the data collection took place; on the other hand, the analysis begins in 2005 to ensure data quality since CrunchBase coverage gets spotty before then. Furthermore, because not all individuals on CrunchBase can be traced back to a specific metropolitan area, I used LinkedIn to search for those individuals with missing location information, thereby reducing the incidence and impact of missing data.

Dependent variables. For Hypothesis 1, the dependent variable is the number of $V C$ backed entrepreneurs within the MSA in year $t$, as reported on CrunchBase. As far as the operationalization of this variable is concerned, in this study I focus on VC-backed entrepreneurs to ensure data quality and representativeness. This is because CrunchBase, which mainly relies on crowdsourcing for information, is notoriously characterized by uneven information quality, especially for what concerns individuals. In other words, CrunchBase is likely characterized by non-random missing data; however, limiting the scope of this study to VC-backed entrepreneurs allows for greater accuracy, insofar as these entrepreneurs tend to appear on CrunchBase at a much higher rate, and their information is typically verified and triangulated by staff using additional data sources such as the website AngelList, as well as commercial databases covering venture 
capital, such as VentureSource and VentureXpert. Individuals are assumed to become VC-backed entrepreneurs - thereby being counted for the purposes of variable construction-when the first venture they founded receives VC funding, and to remain so throughout the observation period.

For Hypothesis 2, the dependent variable is the number of VC-backed entrepreneurs that transitioned to angel investing within the MSA up to year $t$. To compute this variable, I first considered the VC-backed entrepreneurs listed on CrunchBase, identified using the procedure described above. Then, I coded entrepreneurs as having made the transition to angel investing when they are recorded in CrunchBase as having made their first personal investment in a venture other than their own; these individuals are then assumed to be active angel investors thereafter. Once again, I chose this operationalization to ensure data quality and accuracy, at the cost of a reduced sample size. While a majority of angels nationwide are current or former entrepreneurs, there are undoubtedly many who have had careers in other fields — such as banking and financeand who therefore might not appear in the dataset. On the other hand, maintaining a narrow focus on entrepreneurs - even at the cost of reduced generalizability - allows me to examine a rather homogenous set of individuals, thereby setting up a somewhat cleaner empirical test.

Finally, as far as Hypothesis 3 is concerned, the relevant dependent variable is the number of investment made by angels in the MSA towards ventures in the same MSA at year $t$. To construct this variable, I simply considered the population of entrepreneurs-turned-angels, as identified in the previous paragraph, and counted the number of investments made towards other companies. I then identified the location of these companies, based on information publicly available on CrunchBase and LinkedIn about them — and only considering those whose headquarters are within the MSA boundaries. In a separate robustness check described in the results section, I also use a modified version of this variable operationalized as the ratio between the number of investments 
made by angels active within the MSA and directed towards ventures located in the same MSA and the overall number of investments made by angels within the MSA (regardless of their destination). Because the denominator of this ratio is zero for most observations in the datawhich reduces the sample size substantially—I only use this variable in robustness checks, rather than in the main results section.

Independent variable. The main independent variable for all hypotheses is the social capital of the focal Metropolitan Statistical Area (MSA). As far as the operationalization of this variable is concerned, Kwon, Heflin, \& Ruef (2013) note that historically two different kinds of measures were used to gauge social capital within communities: trust and social bonds. Insofar as social capital within a well-defined geographic area is defined as the "features of social lifenetworks, norms, and trust - that enable participants to act together more effectively to pursue shared interests" (Putnam, 1995: 664-665), it can be conceptualized "as a community property more than an individual one, and is expressed as the level of social trust and breadth of organizational memberships among residents" (Kwon et al., 2013). Within sociology, however, social trust is typically measured through surveys such as the General Social Survey (GSS) or the Social Capital Community Benchmark Survey (SCCBS), which cover a variety of geographical areas across the United States. These datasets, however, have several drawbacks that make them unsuitable for the purposes of this study. While SCCBS contains information about a fairly large number of respondents in each geographical area, it is not conducted annually and it focuses on a limited number of communities without covering all U.S. states; further, it not does contain multiple-year observations in the same geographic areas, making a panel-type study all but impossible. Conversely, the General Social Survey (GSS) is conducted annually and also includes measures of trust; however, even with the confidential micro-level data provided through the 
Public Use Microdata Sample (PUMS), the dataset: a) does not adequately cover all MSAs every year in our observation window; and b) only contains information about a fairly limited number of respondents in each MSA, which poses validity concerns. In all, the data currently available does not allow to set up a yearly, trust-based measure of social capital that matches our observation window.

This leaves social bonds, which are traditionally operationalized—following Putnam (1993) - as a function of patterns of civic engagement within the community, on the grounds that engagement in the activities of civic organizations can "instill in their members habits of economic cooperation, solidarity, and public spiritedness" (Putnam, 1993: 89-90). Empirically, therefore, this has resulted in social capital being measured as the density of voluntary and nonprofit associations - i.e. the associational density —within the community. This is because cooperation and information sharing are presumed to be facilitated and catalyzed when opportunities for socialization - and dedicated spaces where socialization can take place-are numerous. For the purposes of this study, I thus operationalize social capital as the number of nonprofit and voluntary organizations within the MSA, as described and identified by Rupasingha, Goetz, \& Freshwater (2006), which describes a methodology for the calculation of social capital at the county level. In brief, for each county in year $t \mathrm{I}$ counted the number of establishments in the following categories: a) civic organizations; b) bowling centers; c) golf clubs; d) fitness centers; e) sports organizations; f) religious organizations; g) political organizations; (h) labor organizations; i) business organizations; and j) professional organizations. To obtain a MSA-level measure, I then added up the number of establishments in all counties the MSA comprises, and then divided by the MSA population to obtain a standardized, comparable figure. To implement the procedure described above, I leverage the County Business Patterns (CBP) database, a U.S. Census annual series that 
provides subnational economic data by industry. This series includes the number of establishments, employment during the week of March 12, first quarter payroll, and annual payroll, all reported at the county level and grouped by NAICS code. This allows to identify the type of establishment with precision, insofar as each of the groupings described in the previous paragraph corresponds to a unique NAICS code. ${ }^{24}$

Control variables. To rule out competing explanations and validate my arguments concerning the linkages between social capital, entrepreneurship and angel investing, all of my models include a battery of control variables. First of all, it is imperative to control for other community-level features that might affect entrepreneurship and angel investing other than social capital. To this end, I include variables for the population of the $M S A$, in that more highlypopulated areas might be especially prone to produce more vibrant entrepreneurial ecosystems. Because the availability of disposable income is likely to be associated with the likelihood to engage in angel investing, I also include a variable for the median household income within the MSA, as well as one for the percent of individuals below the poverty line. In a similar fashion, because more highly-educated areas tend to characterized by higher rates of entrepreneurship, I also include variables for the number of higher education establishments. Finally, to control for the general conditions of the local economy, I include a variable for the total number of business establishments within the MSA. Some models also include year dummies and MSA dummies, to

\footnotetext{
${ }^{24}$ Most extant studies of social capital in sociology have relied on General Social Survey (GSS) data for operationalization purposes. While this data undoubtedly represents the gold standard for this type of analysis, as far as its items concerning social trust are concerned, in my case it is unfortunately impossible to obtain a reliable, timedependent estimate of social capital at the county level for each year in my observation window. This is because even the private-use GSS data - which comes with geographic identifiers - represents a cross-sectional probability sample of adults in 100 geographic areas in the contiguous United States (for further details, see Smith, Marsden, Hout, \& Kim, 2010). As a result, yearly GSS data does not cover all MSAs in my sample, making this particular data source poorly suited for the purposes of my analysis.
} 
control for unobserved heterogeneity that is not captured by the remaining control variables. Table 1 reports summary statistics for all variables used, as well as Pearson correlation coefficients.

Insert Table 3.1 about here

\section{RESULTS}

Insert Table 3.2 about here

Table 2 reports the results of fixed-effects panel OLS models where the dependent variable is the logged number of VC-backed entrepreneurs within the MSA; these are used to test Hypothesis 1. Among the models reported, Model 1 includes just control variables, while Model 2 includes year dummies to control for time effects, and Model 3 adds the main independent variable, social capital (measured as associational density). The coefficient for this latter variable is positive and significant, providing support for Hypothesis 1 and indicating that — controlling for other factorsMSAs characterized by higher social capital also tend to produce more (VC-backed) entrepreneurs. The coefficients for some of the control variables are also noteworthy: educational variables-i.e. the number of higher education establishments and the percentage of individuals with a college degree - are positively associated with the number of VC-backed entrepreneurs, as is (predictably) the MSA population, which further corroborates the idea that education plays a key role in the growth and development of entrepreneurial ecosystems. 
To test Hypothesis 2, Table 3 reports fixed-effects panel OLS models for the logged number of VC-backed entrepreneurs-turned-angels within the MSA. Once again, Model 4 includes just control variables, while Model 5 adds time dummies and Model 6 is the full model, inclusive of the social capital variable, whose coefficient is positive and significant, providing support for Hypothesis 2. More generally, the pattern of findings in Model 6 confirms the positive role of education in the growth of ecosystems, especially as the provision of venture financing is concerned. Furthermore, as predicted, economic variables have an impact as well: not only is the coefficient for median household income positive and significant, which was fairly straightforward, but the same is true of the poverty variable. This rather counterintuitive set of findings can perhaps be explained by the fact that the prosperous areas of the U.S. where entrepreneurial ecosystems are more likely to be found and thrive also happen be characterized by high levels of economic inequality.

Insert Table 3.4 about here

Moving on to Hypothesis 3, Table 4 reports fixed-effects panel OLS models for the logged number of angel investments made by angels located in the MSA towards companies in the same MSA. As seen previously, Model 7 includes just control variables, Model 8 incorporates time dummies, and Model 9 is the full model. Once again, the pattern of results confirm a positive association between social capital and within-MSA angel investment, corroborating Hypothesis 3; moreover, the coefficients for control variables are in line with those seen in the previous tables.

Insert Table 3.5 about here 
The results in Table 4, however, could be driven by the overall number of investments made by angels within the MSA, rather than by the number of them that remain within the MSA. To rule out the possibility that this effect might be spurious, therefore, I ran additional fixed-effects, panel OLS models where the dependent variable is the ratio between the investments made by the MSA angels towards ventures located within the same MSA and the total number of angel investments made by the same individuals; the results are reported in Table 5. Because the ratio denominator is zero in most observations, however, these models have a much reduced sample size-less than a tenth of the original number of observations. This notwithstanding, Model 12 in Table 5 shows an effect for social capital that is still positive and significant, albeit at the .10 level-likely a function of the reduction in statistical power.

\section{DISCUSSION}

A long line of inquiry in organizational studies (e.g. Nahapiet \& Ghoshal, 1998; Walker et al., 1997), sociology (Granovetter, 1985, 2005), and entrepreneurship has maintained that patterns of economic exchange rest on the characteristics of the social milieu in which they are embedded. More recently, scholars have also begun looking into whether local, community-level patterns of socialization might have a bearing on entrepreneurship rates (Kwon et al., 2013) as well as on the financing of new ventures and its effectiveness (Samila \& Sorenson, 2017). In this study, my goal was to further research into this area of inquiry by investigating the relationship between the community-level construct of social capital and the trajectory of local entrepreneurial ecosystems, with specific reference to: a) the local prevalence of entrepreneurs; b) the latter's odds of becoming suppliers of capital — that is, angel investors; and c) the degree to which angel investments tend to 
benefit the local community by targeting local ventures, as opposed to ventures based in other metropolitan areas. I did so by leveraging a panel study of Metropolitan Statistical Areas (MSAs) in the United States between 2005 and 2015, with information on entrepreneurs, angel investors, ventures and funding rounds pulled from CrunchBase. In so doing, I found that: 1) controlling for economic and demographic variables, communities characterized by higher social capital tend to produce significantly more entrepreneurs; 2) the entrepreneurs produced by each MSA tend to transition to angel investing at a higher rate when community social capital is greater; and 3) in the same areas, angel investors will also be comparatively more likely to finance ventures within the community. Overall, the pattern of empirical results I obtained suggests a catalyzing role for community-level social capital as far as the entrepreneurial ecosystem is concerned: communities characterized by greater interconnectedness, and by the availability of socialization spaces where human interaction across entrenched social barriers can take place, are at an advantage when it comes to developing and growing a local entrepreneurial ecosystem. This is because the wealth of social ties and opportunities for interaction that characterize communities that are rich in social capital favor information exchange, opportunity discovery and identification, as well as a greater sense of involvement and belonging in one's social setting.

It is my contention that these results contribute to the literatures previously mentioned in several ways. For what pertains to entrepreneurship, this study highlights how social capital can catalyze entrepreneurs' transition to angel investing and their capital allocation choices, which is relevant insofar as such choices help shape both founding and funding processes (Hellmann \& Thiele, 2018). Organizational scholars and economic sociologists might derive insights from my study for what pertains to the extent to which social dynamics drive market entry in venture financing, and how capital allocation decisions-long the domain of finance scholars—can 
actually being explained through sociological theorizing. And finance scholars might equally find the results to be of interest, since they show how individuals choose to become suppliers of capital (Brown et al., 2008; Hong et al., 2004) and what social processes might help shape capital allocation.

Although my theoretical arguments and empirical results offer some insights that are useful for the scholarly understanding of ecosystem dynamics, the following limitations of my study must also be noted. First of all, for what pertains to the entrepreneurship literature, I must point out that while CrunchBase's coverage of the entrepreneurial ecosystem is fairly comprehensive, and especially so for those ventures that have received $\mathrm{VC}$ funding at any point, my data is not especially suitable for studying entrepreneurship in the United States at large. This is not just because the ventures listed in CrunchBase represent an infinitely small fraction of all U.S. ventures, but predominantly due to the fact that entrepreneurship is an extremely varied and diverse phenomenon, potentially comprising everything from Facebook to a one-man design studio, or a bodega. My conclusions, therefore, likely do not generalize to new businesses at large, but only for those of interest to angel investors and venture capital—-that is, ventures with the potential for high-growth. Second, the process through which I constructed my analytical sample only considers VC-backed ventures and their founders. This is in line with other research efforts being undertaken in our field (Ter Wal et al., 2016; Wang et al., 2018), while simultaneously ensuring that ventures and founders meet a minimum quality threshold; yet, many startups fail to receive venture capital and as such their founders, as well as the investments they receive from angels, fail to appear in my study. The future availability of improved data sources or a more comprehensive coverage of non-VC-funded ventures by CrunchBase will hopefully allow to circumvent this problem. Third, my results only reflect the behavior of angel investors who have been entrepreneurs. As previously 
discussed, current and former entrepreneurs represent a majority of U.S. angel investors, which makes sense insofar as they are perhaps uniquely positioned to do well given their prior knowledge of the ecosystem and their experience raising venture financing. However, angel investors can hail from many other walks of life. While CrunchBase makes it difficult to track these people, different methodological choices - such as studying the outcomes of an angel group that comprises both entrepreneurs and non-entrepreneurs - could perhaps help scholars address this issue at a later date. And finally, in this study I only focus on angel investing, while neglecting other forms of capital supply such as venture capital: this is both because venture capital has been extensively investigated in our field and because it is relatively harder to conceptualize venture capital funding decisions as being taken by individuals

Future research could usefully address these shortcomings and advance research in a variety of potential ways. First and foremost, further work investigating the supply of capital as a social phenomenon is sorely needed. While in this dissertation I have sketched an initial theory of how the supply of capital — as it pertains to entry decisions by individuals, as well as their capital allocation choices—is governed by social mechanisms, as well as by the community characteristics in which ecosystems are embedded, collectively we need to refine the scholarly understanding of the social structure of capital supply. Second, further research could explore the complementarities between angel investing and venture capital (Hellmann, Schure, \& Vo, 2015; Hellmann \& Thiele, 2018), and how each contributes to entrepreneurial growth and, in turn, to ecosystem evolution. Indeed, while both of these forms of venture financing have been explored to a degree, they typically operate in tandem and are not orthogonal to each other-for instance, getting prominent angels on board is seen as a positive signal by venture capitalists, which might make them more likely to get on board. Third, while in this study I have focused on the associational density 
dimension of social capital, the trust dimension is arguably as important, so I am hoping that future work will address the role played by trust in the development of funding relationships, as well as in the growth of ecosystem more broadly. 
Table 3.1. Descriptive statistics and correlation table for all study variables.

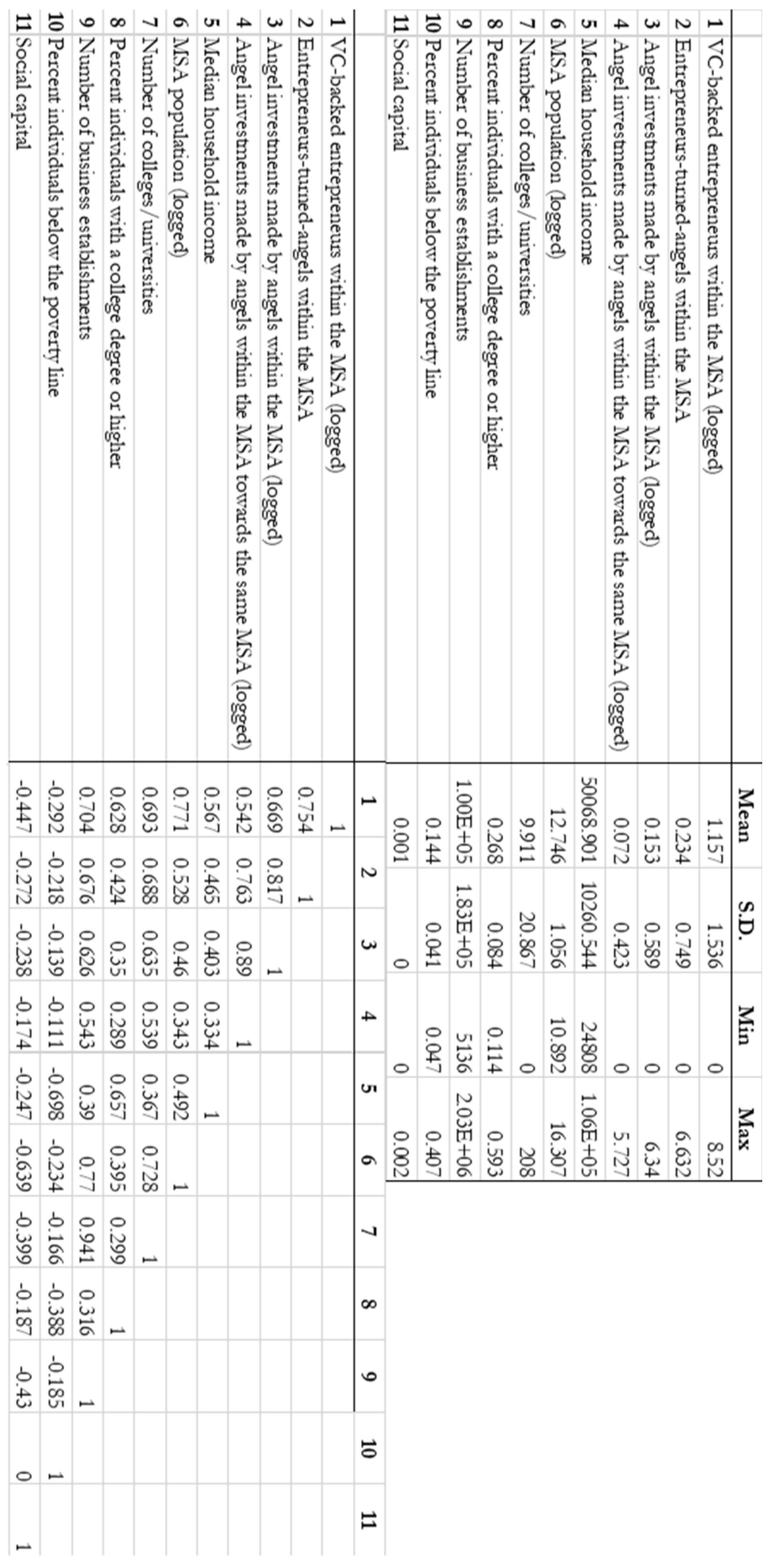


Table 3.2. Fixed-effects panel OLS models for the logged number of VC-backed entrepreneurs within the MSA.

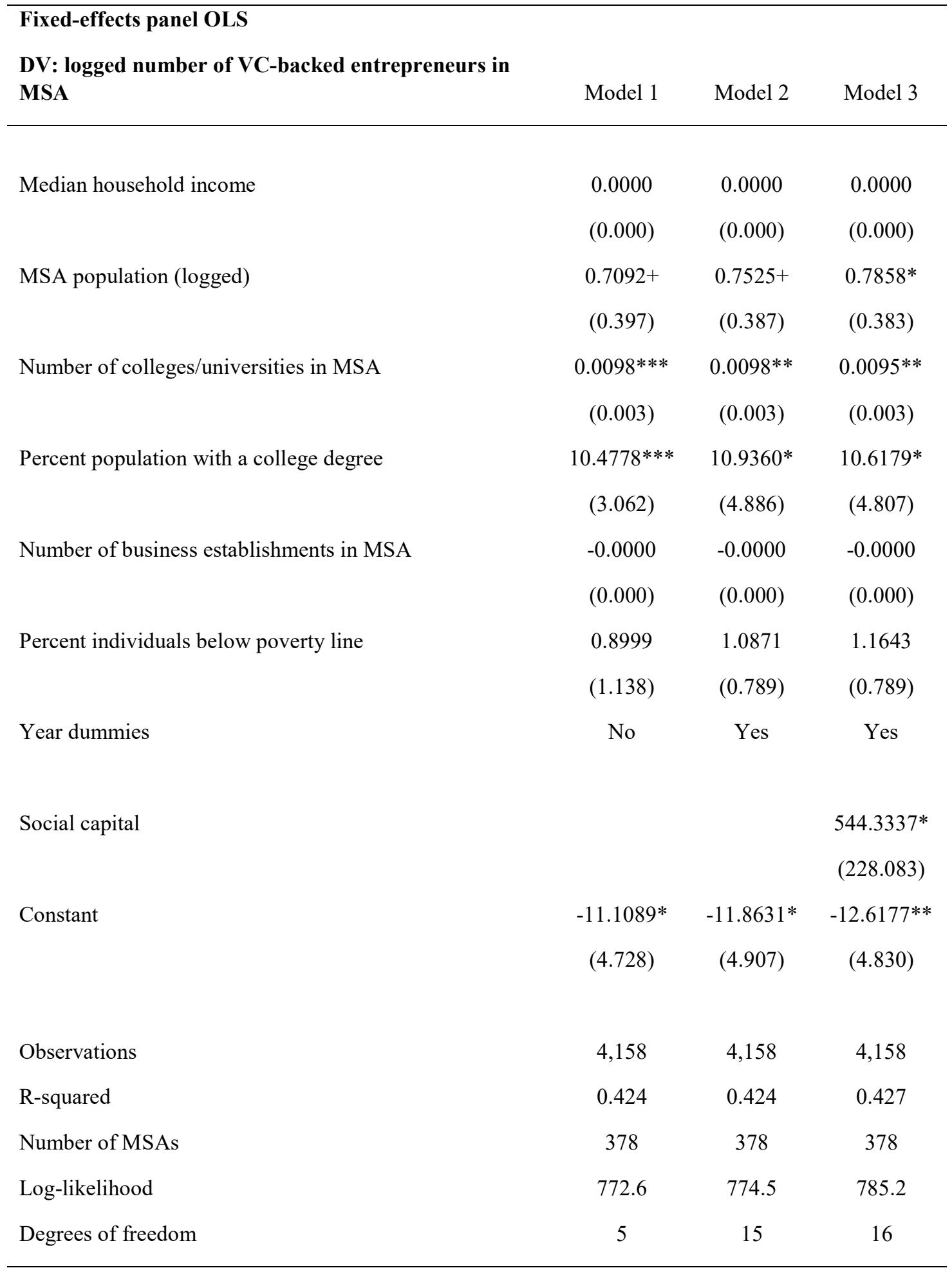

Robust standard errors in parentheses

$* * * \mathrm{p}<0.001,{ }^{* *} \mathrm{p}<0.01, * \mathrm{p}<0.05,+\mathrm{p}<0.10$ 
Table 3.3. Fixed-effects panel OLS models for the logged number of VC-backed entrepreneurs-turnedangels within the MSA.

\begin{tabular}{|c|c|c|c|}
\hline \multicolumn{4}{|l|}{ Fixed-effects panel OLS } \\
\hline DV: logged number of entrepreneurs-turned-angels in MSA & Model 4 & Model 5 & Model 6 \\
\hline \multirow[t]{2}{*}{ Median household income } & $0.0000 * *$ & $0.0000 * * *$ & $0.0000 * * *$ \\
\hline & $(0.000)$ & $(0.000)$ & $(0.000)$ \\
\hline \multirow[t]{2}{*}{ MSA population (logged) } & -0.0544 & 0.0748 & 0.0866 \\
\hline & $(0.177)$ & $(0.184)$ & $(0.183)$ \\
\hline \multirow[t]{2}{*}{ Number of colleges/universities in MSA } & $0.0090 * *$ & $0.0091 * *$ & $0.0090 * *$ \\
\hline & $(0.003)$ & $(0.003)$ & $(0.003)$ \\
\hline \multirow[t]{2}{*}{ Percent population with a college degree } & $1.6760 * *$ & $3.0336^{*}$ & $2.9206^{*}$ \\
\hline & $(0.587)$ & $(1.265)$ & $(1.235)$ \\
\hline \multirow[t]{2}{*}{ Number of business establishments in MSA } & $0.0000 * * *$ & $0.0000 * * *$ & $0.0000 * * *$ \\
\hline & $(0.000)$ & $(0.000)$ & $(0.000)$ \\
\hline \multirow[t]{2}{*}{ Percent individuals below poverty line } & 0.0148 & $0.9267 * *$ & $0.9541 * * *$ \\
\hline & $(0.255)$ & $(0.284)$ & $(0.285)$ \\
\hline Year dummies & No & Yes & Yes \\
\hline \multirow[t]{2}{*}{ Social capital } & & & $193.3007^{*}$ \\
\hline & & & $(76.910)$ \\
\hline \multirow[t]{2}{*}{ Constant } & -0.2947 & -2.8002 & -3.0682 \\
\hline & $(2.161)$ & $(2.338)$ & $(2.326)$ \\
\hline Observations & 4,158 & 4,158 & 4,158 \\
\hline R-squared & 0.225 & 0.258 & 0.260 \\
\hline Log-likelihood & 3456 & 3546 & 3552 \\
\hline Degrees of freedom & 5 & 15 & 16 \\
\hline Number of MSAs & 378 & 378 & 378 \\
\hline
\end{tabular}

Robust standard errors in parentheses

$* * * \mathrm{p}<0.001, * * \mathrm{p}<0.01, * \mathrm{p}<0.05,+\mathrm{p}<0.10$ 
Table 3.4. Fixed-effects panel OLS models for the logged number of angel investments made by angels in the MSA towards companies in the same MSA.

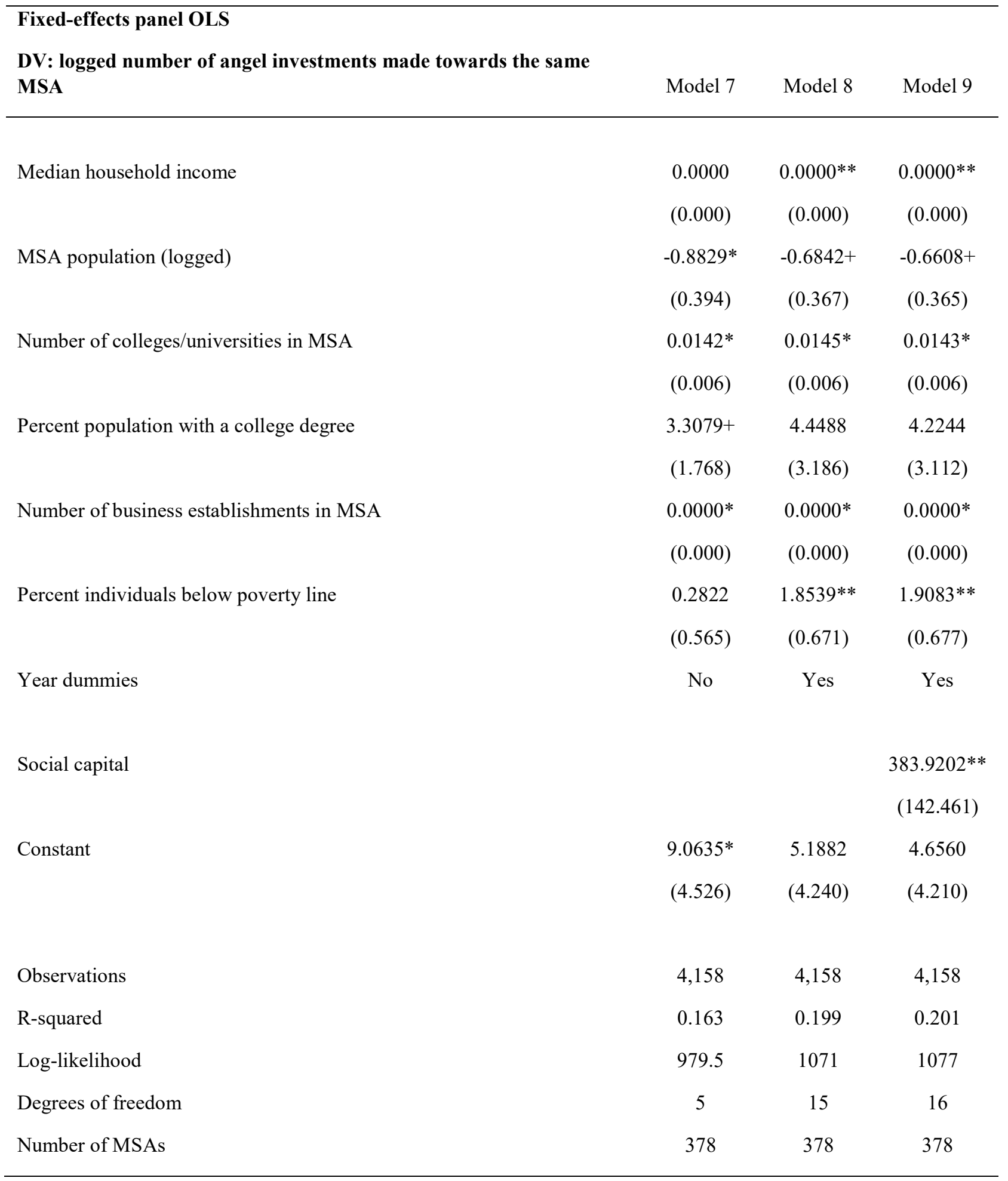


Robust standard errors in parentheses

$* * * \mathrm{p}<0.001,{ }^{* *} \mathrm{p}<0.01,{ }^{*} \mathrm{p}<0.05,+\mathrm{p}<0.10$ 
Table 3.5. Fixed-effects panel OLS models for the ratio of angel investments made by angels in the MSA towards companies in the same MSA to the total number of angel investments made by individuals in the MSA.

\begin{tabular}{|c|c|c|c|}
\hline \multicolumn{4}{|l|}{ Fixed-effects panel OLS } \\
\hline DV: percent angel investments made towards same MSA & Model 10 & Model 11 & Model 12 \\
\hline \multirow[t]{2}{*}{ Median household income } & 0.0000 & 0.0000 & 0.0000 \\
\hline & $(0.000)$ & $(0.000)$ & $(0.000)$ \\
\hline \multirow[t]{2}{*}{ MSA population (logged) } & -1.2937 & -1.1369 & -0.7622 \\
\hline & $(0.792)$ & $(0.912)$ & $(0.896)$ \\
\hline \multirow[t]{2}{*}{ Number of colleges/universities in MSA } & 0.0028 & 0.0022 & 0.0027 \\
\hline & $(0.002)$ & $(0.002)$ & $(0.002)$ \\
\hline \multirow[t]{2}{*}{ Percent population with a college degree } & 1.4088 & 0.6299 & 0.3800 \\
\hline & $(0.868)$ & $(0.758)$ & $(0.698)$ \\
\hline \multirow[t]{2}{*}{ Number of business establishments in MSA } & -0.0000 & 0.0000 & -0.0000 \\
\hline & $(0.000)$ & $(0.000)$ & $(0.000)$ \\
\hline \multirow[t]{2}{*}{ Percent individuals below poverty line } & $6.4399 *$ & 5.1175 & 5.5125 \\
\hline & $(3.225)$ & $(6.138)$ & $(5.927)$ \\
\hline Year dummies & No & Yes & Yes \\
\hline \multirow[t]{2}{*}{ Social capital } & & & $2,613.9833+$ \\
\hline & & & $(1,448.143)$ \\
\hline \multirow[t]{2}{*}{ Constant } & 17.0872 & 15.0326 & 8.7000 \\
\hline & $(10.781)$ & $(13.068)$ & $(12.841)$ \\
\hline Observations & 403 & 403 & 403 \\
\hline R-squared & 0.036 & 0.057 & 0.067 \\
\hline Log-likelihood & 46.02 & 50.36 & 52.51 \\
\hline Degrees of freedom & 5 & 15 & 16 \\
\hline Number of MSAs & 94 & 94 & 94 \\
\hline
\end{tabular}

Robust standard errors in parentheses

$* * * \mathrm{p}<0.001,{ }^{* *} \mathrm{p}<0.01,{ }^{*} \mathrm{p}<0.05,+\mathrm{p}<0.10$ 


\section{CONCLUSION}

Throughout its three chapters, this dissertation represents one of the first instances of scholarly inquiry into the informal supply of capital to new ventures to focus primarily on human and social factors - in other words, on its behavioral aspects. The topic of angel investing has certainly been broached before (Shane, 2008; Van Osnabrugge \& Robinson, 2000), and often at length; yet, venture financing by individuals remains an interesting empirical puzzle for management and entrepreneurship scholars, as well as-I would argue-economic sociologists.

For instance, in Chapter I, I elaborated on the reasons behind individual entrepreneurs' decisions to enter angel investing, insofar as several alternatives that are relatively more profitable and less risky are available to them. As a result, theories in economics and finance that are traditionally used to construct accounts of investor behavior, such as portfolio theory (Markowitz, 1959), largely fail to account for the behavior of angel investors. Qualitative field observation and interviews, however, were suggestive of prosocial motivations being at play: many angels noted that they enjoyed the human component of angel investments, and several remarked that they felt it was their duty to contribute to the entrepreneurial ecosystem they were part of, given that most of them had received assistance by various ecosystem entities in the past. Building on these intuitions, and drawing on multiple strands of the sociology literature, I then develop a behavioral theory of angel investing that draws on the long-standing sociological ideas of generalized reciprocity and homophily to theorize about the processes through which entrepreneurs become angel investors. My empirical results are broadly in agreement with the theory, providing evidence that: 1) founders receiving angel investments are more likely to become angel investors in turn; and 2) this is especially true when founders are financed by angels who are similar to them. 
Furthermore, results also show that homophily is reproduced across "generations" of angel investors, and that entrepreneurs who are financed by angels similar to them tend to invest similar founders as well upon becoming angel investors.

In Chapter II, I then reflected on the problem of performance in angel investing, starting from the premise that early-stage venture financing, of which angel investing is typically part of, is typically carried out in an information vacuum. Because entrepreneurs typically seek money from angels in the pre-revenue stage, there is a dearth of information available on the objective value of an entrepreneurial idea, as well as about the founding team's ability to successfully execute it. As a result, angel investors implement a variety of uncertainty reduction techniques, such as heavily weighing referrals from trusted contacts or relying on homophily as an evaluative heuristic. All of the above has resulted in early-stage venture financing being configured as more of an art than a science, given the lack of strong correlates of performance in angel investing. We have sought to change that by laying out potential antecedents of success in angel investing based on existing debates in the organizational literature concerning what makes individuals effective in certain roles, either within organizations or in market settings at large. In so doing, we find that generalists - i.e. angels who invest across market categories - tend to do comparatively better than angels with more specialized investing profiles. Furthermore, results show that this effect is moderated by the angel's past experience as a founder-entrepreneurs who founded companies across industries tend to do better when they invest across industries, as well. Results also show that an individual's success as a founder - in terms of founding ventures that were acquired or went public_correlates with later success as an investor, presumably because success in entrepreneurship, being an exceedingly rare event, offers unique opportunities for learning. The effect of entrepreneurial success on angel investing success is also moderated by the degree of 
overlap between the industries in which the angel invests and those in which (s)he founded companies; this suggests that the "lessons learned" from success do not apply universally, but rather are contingent on the degree to which it is relevant to the task at hand.

Finally, in Chapter III I examine the interrelations between venture financing and the communities in which entrepreneurial ecosystems are embedded. This is a germane question, insofar as qualitative evidence from interviews and field observation has shown that social considerations drive both the decision to enter angel investing and, once individuals take this step, the choice of investments. The construct of social capital, as used in sociology (Putnam, 1993), is therefore uniquely apt to model the degree to which social ties at the community level shape ecosystem dynamics, as it is a parsimonious measure of the strength of social ties within the communities, its interconnectedness, and the availability of spaces where socialization can take place. In this regard, my results show that Metropolitan Statistical Areas (MSAs) with greater social capital: 1) produce more entrepreneurs; 2) see a greater share of these become angel investors; and 3) are characterized a greater share of investment targeted towards ventures in the community. This pattern of findings speaks to the importance of community-level social structures in determining the direction a given ecosystem will evolve towards; social capital, in particular, appears to correlate strongly with a greater community orientation, as well as with a greater prevalence of informal funding relationships.

Beyond the specificities of my empirical setting, I maintain my results offer useful contributions to organizational studies, the entrepreneurship literature, and the scholarly knowledge of the intersection between ecosystems and communities more generally. One relevant theme that cuts across the whole dissertation concerns entry into capital markets by individuals: why do individuals decide to become suppliers of capital? My findings across the three chapters 
show that beyond individual proclivities and genetic factors, the social context plays a substantial role in determining the transition from entrepreneurship to angel investing. Entrepreneurs are not just more likely to become angels when they have been financed by angels, thereby being exposed to their activities and "primed" to follow their lead; rather, community-level structures play a role too, insofar as communities that offer greater opportunities for socialization and for the formation of social ties tend to fare better, in terms of both the number of angel investors relative to the population and the fraction of investments that target ventures in the same community. Similar arguments, I believe, could be made in the case of entry decisions in other types of markets, such as crowdfunding, venture capital, or microfinance. In a similar fashion, as far as performance in angel investing is concerned, I believe our arguments are not specific to our empirical setting but could easily be generalized to other settings. In particular, our considerations on the role of specialization—which were, in turn, extrapolated from Lazear's (2004) arguments about entrepreneurship - could potentially apply to many types of investors, including venture capitalists. While the generalizability of the above findings is, in my opinion, quite broad, the mechanisms discussed above likely affect different types of investors differently, so it might be of substantial theoretical interest to examine the boundary conditions of my arguments as they are extended to different types of investments.

While I do believe my work offers useful contributions to the literature, as well as to the scholarly understanding of angel investing, some of its (general) limitations must be noted. Throughout the dissertation, I have limited my analyses to a sub-sample of angel investors: those with past entrepreneurial experience. I have done so primarily because of data availability issue, but I also considered this setup advantageous insofar as it allowed me to test my arguments on a relatively homogenous sample of individuals. While most angel investors in the U.S. have been 
entrepreneurs at some point however, many others—especially in New York City—come from the private sector, with banking, consulting and finance being the most common paths leading to angel investing. These investors tend to be older, as they often begin pursuing angel investing when they are close to retiring, and their motives and investment styles likely differ from those of former entrepreneurs. For this reason, any extension of my arguments to this sub-population should be taken with a grain of salt. I am hopeful, however, to be able to collect data on non-entrepreneur angels in the future, and to weigh the extent to which their behavior differs from those of former entrepreneurs. Another limitation worth noting concerns the process through which the main dataset was constructed: because Crunchbase—being crowdsourced—does not cover all ventures with an equal level of detail, and because venture-backed startups tend to have much better information available, I limited by analysis to such ventures, and to their founders. This likely introduces bias, in that ventures that receive VC funding are likely of above average quality relative to the total population. The same problem also extends to the angel investor sample: because I only consider former entrepreneurs, and because all former entrepreneurs in the sample have received venture capital funding at some point, the sample likely excludes slightly less successful entrepreneurs who might have become angels nonetheless. In the future, assuming better data sources are available, I would like to relax this constraint and explore any and all angel investors I might have left out of this initial sample. Finally, due to budgetary constraints I was only able to carry out interviews and participant observation at a limited number of locations in the Tri-State area centered around New York City, with the lone exception of my attendance of the annual Angel Capital Association meeting. Because some of the arguments made in my dissertation, especially as it pertains to Chapter III, hinge on geographic variation in factors like social capital, I hope that 
in the future I will be able to carry out fieldwork in other areas of the country, as well, and possibly abroad.

Taken in their entirety, I believe my findings also open up interesting opportunities for further empirical research, as many interesting questions remain unexplored. For instance, the behavioral side of investing, which my work highlights, could be explored in other forms of investing, both within the ecosystem (e.g. crowdfunding, venture capital) and beyond. Further work could also highlight the complementarities between the above forms of venture financingfor instance, raising a successful round of angel investments is often a prelude to receiving venture capital funding. Chapter III also offers interesting opportunities for further inquiry between the folds of existing findings. For instance, the poverty variable shows a strong association with the fraction of entrepreneurs who become angel investors. This is interesting, insofar as extant research has shown that economic inequality is generally associated with negative outcomes; for instance, innovativeness tends to be lower in contexts with high inequality (although see Aghion, Akcigit, Bergeaud, Blundell, \& Hémous, 2015). Therefore, hope that further studies will tackle the effects of economic inequality on entrepreneurial ecosystems head on. The same is true for several other variables of interest to sociologists, such as racial integration (e.g. see Levine et al., 2014), which might also be predictive of ecosystem-level outcomes. In all, it is my hope that these loose ends will be eventually picked up and given the theoretical and empirical attention they deserve. 


\section{BIBLIOGRAPHY}

Abraham, M. L. 2014. Explaining Unequal Returns to Social Capital Among Entrepreneurs. Working paper.

Adler, P. S., \& Kwon, S.-W. 2002. Social Capital: Prospects for a New Concept. Academy of Management Review, 27(1): 17-40.

Aghion, P., Akcigit, U., Bergeaud, A., Blundell, R., \& Hémous, D. 2015. Innovation and Top Income Inequality. Cambridge, MA. https://doi.org/10.3386/w21247.

Aldrich, H. 1989. Networking Among Women Entrepreneurs. In O. Hagan, C. Rivchun, \& D. Sexton (Eds.), Women-owned businesses, vol. 103: 132. Praeger.

Alesina, A., \& La Ferrara, E. 2000. Participation in Heterogeneous Communities. Quarterly Journal of Economics, 115(3): 847-904.

Alesina, A., \& La Ferrara, E. 2014. Ethnic Diversity and Economic Performance. Journal of Economic Literature, 43(3): 762-800.

Aoyama, Y. 2009. Entrepreneurship and Regional Culture: The Case of Hamamatsu and Kyoto, Japan. Regional Studies, 43(3): 495-512.

Aral, S., Muchnik, L., \& Sundararajan, A. 2009. Distinguishing Influence-based Contagion from Homophily-driven Diffusion in Dynamic Networks. Proceedings of the National Academy of Sciences of the United States of America, 106(51): 21544-21549.

Åstebro, T., \& Thompson, P. 2011. Entrepreneurs, Jacks of all trades or Hobos? Research Policy, 40(5): 637-649.

Audia, P. G., Freeman, J. H., \& Davidson, P. 2006. Organizational Foundings in Community Context: Manufacturers and Their Interrelationship with Other Organizations. Administrative Science Quarterly, 51(3): 83-92.

Battilana, J., \& Lee, M. 2014. Advancing Research on Hybrid Organizing - Insights from the Study of Social Enterprises. Academy of Management Annals, 8(1): 397-441.

Baum, J. A. C., \& Dahlin, K. B. 2007. Aspiration Performance and Railroads' Patterns of Learning from Train Wrecks and Crashes. Organization Science, 18(3): 368-385.

Becker, G. S., \& Murphy, K. M. 1992. The Division of Labor, Coordination Costs, and Knowledge. Quarterly Journal of Economics, 107(4): 1137-1160.

Bidwell, M., \& Briscoe, F. 2010. The Dynamics of Interorganizational Careers. Organization Science, 21(5): 1034-1053.

Bielby, W. T., \& Baron, J. N. 1986. Men and Women at Work: Sex Segregation and Statistical Discrimination. American Journal of Sociology, 91(4): 759-799.

Billig, M., \& Tajfel, H. 1973. Social Categorization and Similarity in Intergroup Behaviour. European Journal of Social Psychology, 3(1). 
Blau, P. M., Gustad, J. W., Jessor, R., Parnes, H. S., \& Wilcock, R. C. 1956. Occupational Choice: A Conceptual Framework. ILR Review, 9(4): 531-543.

Bourdieu, P. 1985. The Forms of Capital. In J. Richardson (Ed.), Handbook of Theory and Research for the Sociology of Education: 241-258. New York, NY: Greenwood.

Brass, D. J. 1985. Men's and Women's Networks: A Study of Interaction Patterns and Influence in an Organization. Academy of Management Journal, 28(2): 327-343.

Brooks, A. W., Huang, L., Kearney, S. W., \& Murray, F. E. 2014. Investors Prefer Entrepreneurial Ventures Pitched by Attractive Men. Proceedings of the National Academy of Sciences, 111(12): 4427-4431.

Brown, J. R., Ivković, Z., Smith, P. A., \& Weisbenner, S. 2008. Neighbors Matter: Causal Community Effects and Stock Market Participation. Journal of Finance, 63(3): 1509_ 1531.

Budescu, D. V., \& Chen, E. 2015. Identifying Expertise to Extract the Wisdom of Crowds. Management Science, 61(2): 267-280.

Burt, R. S. 1992. Structural Holes: The Social Structure of Competition. Cambridge, MA: Harvard University Press.

Burton, M. D., Sørensen, J. B., \& Dobrev, S. D. 2016. A Careers Perspective on Entrepreneurship. Entrepreneurship: Theory and Practice, 40(2): 237-247.

Canales, R., \& Greenberg, J. 2016. A Matter of (Relational) Style: Loan Officer Consistency and Exchange Continuity in Microfinance. Management Science, 62(4): 1202-1224.

Carlile, P. R. 2002. A Pragmatic View of Knowledge and Boundaries: Boundary Objects in New Product Development. Organization Science, 13(4): 442-455.

Carlile, P. R. 2004. Transferring, Translating, and Transforming: An Integrative Framework for Managing Knowledge Across Boundaries. Organization Science, 15(5): 555-568.

Carruthers, B. G., \& Kim, J.-C. 2011. The Sociology of Finance. Annual Review of Sociology, 37(1): 239-259.

Centola, D. 2011. An Experimental Study of Homophily in the Adoption of Health Behavior. Science, 334(6060): 1269-72.

Chiang, Y. S., \& Takahashi, N. 2011. Network Homophily and the Evolution of the Pay-ItForward Reciprocity. PLOS ONE, 6(12). https://doi.org/10.1371/journal.pone.0029188.

Clogg, C., Petkova, E., \& Haritou, A. 1995. Statistical Methods for Comparing Regression Coefficients Between Models. American Journal of Sociology, 100(5): 1261-1293.

Cohen, W. M., \& Levinthal, D. A. 1990. Absorptive Capacity: A New Perspective on Learning and Innovation. Administrative Science Quarterly, 35(1): 128-152.

Coleman, J. S. 1988. Social Capital in the Creation of Human Capital. American Journal of Sociology, 94(s1): S95.

Coleman, J. S., Katz, E., \& Menzel, H. 1957. The Diffusion of an Innovation Among Physicians. 
Sociometry, 20(4): 253-270.

Cumming, D., Walz, U., \& Werth, J. C. 2016. Entrepreneurial Spawning: Experience, Education, and Exit. Financial Review, 51(4): 507-525.

Custódio, C., Ferreira, M. A., \& Matos, P. 2013. Generalists Versus Specialists: Lifetime Work Experience and Chief Executive Officer Pay. Journal of Financial Economics, 108(2): 471-492.

Dahl, M. S., \& Sorenson, O. 2009. The Embedded Entrepreneur. European Management Review, 6(3): 172-181.

Dahl, M. S., \& Sorenson, O. 2010. The Social Attachment to Place. Social Forces, 89(2): 633658.

Dahl, M. S., \& Sorenson, O. 2012. Home Sweet Home: Entrepreneurs' Location Choices and the Performance of Their Ventures. Management Science, 58(6): 1059-1071.

Davis, G. F., \& Greve, H. R. 1997. Corporate Elite Networks and Governance Changes in the 1980s. American Journal of Sociology, 103(1): 1-37.

Deichmann, D., \& Ende, J. van den. 2014. Rising from Failure and Learning from Success: The Role of Past Experience in Radical Initiative Taking. Organization Science, 25(3): 670690.

Dezso, C. L., Ross, D. G., \& Uribe, J. 2016. Is There An Implicit Quota on Women in Top Management? A Large-Sample Statistical Analysis. Strategic Management Journal, 37(1): $98-115$.

Dobrev, S. D., \& Barnett, W. P. 2005. Organizational Roles and Transition to Entrepreneurship. Academy of Management Journal, 48(3): 433-449.

Durkheim, E. 1997. The Division of Labor in Society.

Ellis, H. C. 1965. The Transfer of Learning. New York, NY: Macmillan.

Ellis, S., \& Davidi, I. 2005. After-Event Reviews: Drawing Lessons from Successful and Failed Experience. Journal of Applied Psychology, 90(5): 857-871.

Ellis, S., Mendel, R., \& Nir, M. 2006. Learning from Successful and Failed Experience: The Moderating Role of Kind of After-Event Review. Journal of Applied Psychology, 91(3): 669-680.

Estes, W. K. 1970. Learning Theory and Mental Development. New York, NY: Academic Press.

Falck, O., Heblich, S., \& Luedemann, E. 2012. Identity and Entrepreneurship: Do School Peers Shape Entrepreneurial Intentions? Small Business Economics, 39(1): 39-59.

Ferguson, J.-P., \& Hasan, S. 2013. Specialization and Career Dynamics: Evidence from the Indian Administrative Service. Administrative Science Quarterly. https://doi.org/10.1177/0001839213486759.

Fernandez, R. M., Castilla, E. J., \& Moore, P. 2000. Social Capital at Work: Networks and 
Employment at a Phone Center. American Journal of Sociology, 105(5): 1288-1356.

Ferrary, M., \& Granovetter, M. 2009. The role of venture capital firms in Silicon Valley's complex innovation network. Economy and Society, 38(2): 326-359.

Galaskiewicz, J., \& Shatin, D. 1981. Leadership and Networking among Neighborhood Human Service Organizations. Administrative Science Quarterly, 26(3): 434-448.

Gans, H. 2008. Popular Culture and High Culture: An Analysis and Evaluation of Taste. New York, NY: Basic Books.

Gertler, M. S. 2004. Manufacturing Culture: The Institutional Geography of Industrial Practice. Oxford, UK: Oxford University Press.

Gompers, P. A., Mukharlyamov, V., \& Xuah, Y. 2016. The Cost of Friendship. Journal of Financial Economics, 119(3): 626-644.

Gompers, P., Kovner, A., Lerner, J., \& Scharfstein, D. 2010. Performance Persistence in Entrepreneurship. Journal of Financial Economics, 96(1): 18-32.

Granovetter, M. 1973. The Strength of Weak Ties. American Journal of Sociology, 78(6): $1360-1380$.

Granovetter, M. 1985. Economic Action and Social Structure: The Problem of Embeddedness. American Journal of Sociology, 91(3): 481-510.

Granovetter, M. 2005. The Impact of Social Structure on Economic Outcomes. Journal of Economic Perspectives, 19(1): 33-50.

Greenberg, J., \& Mollick, E. 2017. Leaning In or Leaning On? Gender, Homophily, and Activism in Crowdfunding. Administrative Science Quarterly. https://doi.org/10.5465/AMBPP.2015.18365abstract.

Greenstein, S., \& Zhu, F. 2018. Do Experts or Crowd-Based Models Produce More Bias? Evidence from Encyclopedia Britannica and Wikipedia. MIS Quarterly.

Groysberg, B., Lee, L.-E., \& Nanda, A. 2008. Can They Take It With Them? The Portability of Star Knowledge Workers’ Performance. Management Science, 54(7): 1213-1230.

Guiso, L., Sapienza, P., \& Zingales, L. 2008. The Role of Social Capital in Financial Development. American Economic Review, 94(3): 526-556.

Hansen, M. T. 1999. The Search-Transfer Problem: The Role of Weak Ties in Sharing Knowledge across Organization Subunits. Administrative Science Quarterly, 44(1): 82111.

Haveman, H. A. 1993. Follow the Leader: Mimetic Isomorphism and Entry Into New Markets. Administrative Science Quarterly, 38(4): 593-627.

Hegde, D., \& Tumlinson, J. 2014. Does Social Proximity Enhance Business Partnerships? Theory and Evidence from Ethnicity's Role in U.S. Venture Capital. Management Science, 60(9): 2355-2380.

Hellmann, T. F., Schure, P. H., \& Vo, D. H. 2015. Angels and Venture Capitalists: Complements 
or Substitutes? Working Paper. https://doi.org/10.2139/ssrn.2602739.

Hellmann, T., \& Puri, M. 2002. Venture Capital and the Professionalization of Start-up Firms: Empirical Evidence. Journal of Finance, 57(1): 169-197.

Hellmann, T., \& Thiele, V. 2018. Fostering Entrepreneurship: Promoting Founding or Funding? Management Science. https://doi.org/10.2139/ssrn.2908955.

Hochberg, Y. V., Lindsey, L. A., \& Westerfield, M. M. 2015. Resource Accumulation through Economic Ties: Evidence from Venture Capital. Journal of Financial Economics, 118(2): 245-267.

Hochberg, Y. V., Ljungqvist, A., \& Lu, Y. 2007. Whom You Know Matters : Venture Capital Networks and Investment Performance. Journal of Finance, 62(1): 251-301.

Hochberg, Y. V., Ljungqvist, A., \& Lu, Y. 2010. Networking as a Barrier to Entry and the Competitive Supply of Venture Capital. Journal of Finance, 65(3): 829-859.

Hong, H., Kubik, J. D., \& Stein, J. C. 2004. Social Interaction and Stock-Market Participation. Journal of Finance, 59(1): 137-163.

Hsu, D. H. 2004. What Do Entrepreneurs Pay for VC Affiliation? Journal of Finance, 59(4): $1805-1844$.

Huang, L. A., \& Knight, A. P. 2017. Resources and Relationships in Entrepreneurship: An Exchange Theory of the Development and Effects of the Entrepreneur-Investor Relationship. Academy of Management Review, 42(1): 80-102.

Huang, L. A., \& Pearce, J. L. 2015. Managing the Unknowable: The Effectiveness of Early-stage Investor Gut Feel in Entrepreneurial Investment Decisions. Administrative Science Quarterly, 60(4): 635-670.

Ibarra, H. 1992. Homophily and Differential Returns: Sex Differences in Network Structure and Access in an Advertising Firm. Administrative Science Quarterly, 37(3): 422-447.

Jensen, M. 2003. The Role of Network Resources in Market Entry: Commercial Banks' Entry into Investment Banking, 1991-1997. Administrative Science Quarterly, 48(3): 466-497.

Jorgenson, D. W. 1963. Capital Theory and Investment Behavior. American Economic Review, 53(2): 247-259.

Kacperczyk, A. J. 2013. Social Influence and Entrepreneurship: The Effect of University Peers on Entrepreneurial Entry. Organization Science, 1-20.

Kahneman, D., \& Tversky, A. 1979. Prospect Theory: An Analysis of Decision under Risk. Econometrica, 47(2): 263-292.

Kanter, R. M. 1977. Men and Women of the Corporation. New York, NY: Basic Books.

Kanze, D., Conley, M., Huang, L. A., \& Higgins, E. T. 2018. We Ask Men to Win \& Women Not to Lose: Closing the Gender Gap in Startup Funding. Academy of Management Journal, 61(2): 586-614.

Kaustia, M., \& Knüpfer, S. 2012. Peer Performance and Stock Market Entry. Journal of 
Financial Economics, 104(2): 321-338.

Kerr, W. R., Lerner, J., \& Schoar, A. 2014. The Consequences of Entrepreneurial Finance:

Evidence from Angel Financings. Review of Financial Studies, 27(1): 20-55.

Khan, S. R. 2012. The Sociology of Elites. Annual Review of Sociology, 38(1): 361-377.

Knack, S., \& Keefer, P. 1997. Does Social Capital Have an Economic Payoff? A Cross-Country Investigation. Quarterly Journal of Economics, 112(4): 1251-1288.

Kogut, B., Urso, P., \& Walker, G. 2007. Emergent Properties of a New Financial Market: American Venture Capital Syndication, 1960-2005. Management Science.

Kraatz, M. S. 1998. Learning by Association? Interorganizational Networks and Adaptation to Environmental Change. Academy of Management Journal, 41(6): 621-643.

Kwon, S.-W., \& Adler, P. S. 2014. Social Capital: Maturation of a Field of Research. Academy of Management Review, 39(4): 412-422.

Kwon, S.-W., Heflin, C., \& Ruef, M. 2013. Community Social Capital and Entrepreneurship. American Sociological Review, 78(6): 980-1008.

Lazear, E. P. 2004. Balanced Skills and Entrepreneurship. American Economic Review, 94(2): 208-211.

Lazear, E. P. 2005. Entrepreneurship. Journal of Labor Economics, 23(4): 649-680.

Lee, S. Y., Florida, R., \& Acs, Z. J. 2004. Creativity and Entrepreneurship: A Regional Analysis of New Firm Formation. Regional Studies, 38(8): 879-891.

Lerner, J., \& Malmendier, U. 2013. With a Little Help from My (Random) Friends: Success and Failure in Post-Business School Entrepreneurship. Review of Financial Studies, 26(10): 2411-2452.

Lerner, J., Schoar, A., Sokolinski, S., \& Wilson, K. 2016. The Globalization of Angel Investments: Evidence across Countries.

Levine, A. 1976. Educational and Occupational Choice: A Synthesis of Literature from Sociology and Psychology. Journal of Consumer Research, 2(4): 276-289.

Levine, S. S., Apfelbaum, E. P., Bernard, M., Bartelt, V. L., Zajac, E. J., et al. 2014. Ethnic Diversity Deflates Price Bubbles. Proceedings of the National Academy of Sciences, 111(52): 18524-18529.

Levitt, B., \& March, J. G. 1988. Organizational Learning. Annual Review of Sociology, 14(1): 319-340.

Lindsey, L. 2008. Blurring Firm Boundaries: The Role of Venture Capital in Strategic Alliances. Journal of Finance, 63(3): 1137-1168.

Madsen, P. M., \& Desai, V. M. 2010. Failing To Learn? the Effects of Failure and Success on Organizational Learning in the Global Orbital Launch Vehicle Industry. Academy of Management Journal, 53(3): 451-476. 
March, J. G., Sproull, L. S., \& Tamuz, M. 1991. Learning from Samples of One or Fewer. Organization Science, 2(1): 1-13.

Markowitz, H. 1959. Portfolio Selection: Efficient Diversification of Investments. New York: Wiley.

Marquis, C., \& Tilcsik, A. 2013. Imprinting: Toward A Multilevel Theory. Academy of Management Annals, 7(1): 193-243.

Mason, C. M., \& Harrison, R. T. 2002. Is It Worth It? The Rates of Return from Informal Venture Capital Investments. Journal of Business Venturing, 17(3): 211-236.

McPherson, M., Smith-Lovin, L., \& Cook, J. M. 2001. Birds of a Feather: Homophily in Social Networks. Annual Review of Sociology, 27(1): 415-438.

Merluzzi, J., \& Phillips, D. J. 2016. The Specialist Discount: Negative Returns for MBAs with Focused Profiles in Investment Banking. Administrative Science Quarterly, 61(1): 87-124.

Mitteness, C. R., DeJordy, R., Ahuja, M. K., \& Sudek, R. 2016. Extending the Role of Similarity Attraction in Friendship and Advice Networks in Angel Groups. Entrepreneurship Theory and Practice, 40(3): 627-655.

Mollick, E. R., \& Nanda, R. 2016. Wisdom or Madness? Comparing Crowds with Expert Evaluation in Funding the Arts. Management Science, 62(6): 1533-1553.

Molm, L. D., Collett, J. L., \& Schaefer, D. R. 2007. Building Solidarity through Generalized Exchange: A Theory of Reciprocity. American Journal of Sociology, 113(1): 205-242.

Muehlfeld, K., Sahib, P. R., \& van Witteloostuijn, A. 2012. A Contextual Theory of Organizational Learning From Failures and Successes: A Study of Acquisition Completion in the Global Newspaper Industry, 1981-2008. Strategic Management Journal, 33(8): 938-964.

Mulcahy, D., Weeks, B., \& Bradley, H. S. 2012. We Have Met the Enemy...and He is Us: Lessons from Twenty Years of the Kauffman Foundation's Investments in Venture Capital Funds and the Triumph of Hope Over Experience. Kansas City, MO. https://doi.org/10.3821/1913-701X-143.1.5.a.

Mungai, E., \& Velamuri, S. R. 2011. Parental Entrepreneurial Role Model Influence on Male Offspring: Is It Always Positive and When Does It Occur? Entrepreneurship: Theory and Practice, 35(2): 337-357.

Nahapiet, J., \& Ghoshal, S. 1998. Social Capital, Intellectual Capital, and the Organizational Advantage. Academy of Management Review, 23(2): 242-266.

Nanda, R., \& Sørensen, J. B. 2010. Workplace Peers and Entrepreneurship. Management Science, 56(7): 1116-1126.

O’Mahony, S., \& Bechky, B. A. 2006. Stretchwork: Managing the Career Progression Paradox in External Labor Markets. Academy of Management Journal, 49(5): 918-941.

Obukhova, E., Wang, Y., \& Li, J. 2013. The Power of Local Networks: Returnee Entrepreneurs, School Ties, and Firm Performance. Working paper. 
https://doi.org/10.5465/AMBPP.2013.10740abstract.

Pablo-Lerchundi, I., Morales-Alonso, G., \& González-Tirados, R. M. 2015. Influences of Parental Occupation on Occupational Choices and Professional Values. Journal of Business Research, 68(7): 1645-1649.

Pahnke, E. C., Katila, R., \& Eisenhardt, K. M. 2015. Who Takes You to the Dance? How Partners' Institutional Logics Influence Innovation in Young Firms. Administrative Science Quarterly. https://doi.org/10.1177/0001839215592913.

Parker, S. C. 2013. Do Serial Entrepreneurs Run Successively Better-Performing Businesses? Journal of Business Venturing, 28(5): 652-666.

Podolny, J. M. 2001. Networks as the Pipes and Prisms of the Market. American Journal of Sociology, 107(1): 33-60.

Polanyi, K. 1968. The Economy as Instituted Process. In E. LeClair \& E. Schneider (Eds.), Economic Anthropology. New York, NY: Holt, Rinehart and Winston.

Pollock, T. G., \& Rindova, V. P. 2003. Media Legitimation Effects in the Market for Initial Public Offerings. Academy of Management Journal, 46(5): 631-642.

Pollock, T. G., Rindova, V. P., \& Maggitti, P. G. 2008. Market Watch: Information and Availability Cascades Among the Media and Investors in the U.S. IPO Market. Academy of Management Journal, 51(2): 335-358.

Portes, A. 1998. Social Capital: Its Origins and Applications in Modern Sociology. Annual Review of Sociology, 24(1): 1-24.

Portes, A., \& Vickstrom, E. 2011. Diversity, Social Capital, and Cohesion. Annual Review of Sociology, 37(2011): 461-479.

Powell, W. W., \& Snellman, K. 2004. The Knowledge Economy. Annual Review of Sociology, 30(1): 199-220.

Putnam, R. D. 1993. Making Democracy Work: Civic Traditions in Modern Italy. Princeton, NJ: Princeton University Press.

Putnam, R. D. 1995. Tuning In, Tuning Out: The Strange Disappearance of Social Capital in America. PS: Political Science and Politics, 28(4): 664.

Rao, H., Davis, G. F., \& Ward, A. 2000. Embeddedness, Social Identity and Mobility: Why Firms Leave the NASDAQ and Join the New York Stock Exchange. Administrative Science Quarterly, 45(2): 268-292.

Reinstein, D. A., \& Snyder, C. M. 2005. The Influence of Expert Reviews on Consumer Demand for Experience Goods: A Case Study of Movie Critics. The Journal of Industrial Economics, 53(1): 27-51.

Renzulli, L. A., Aldrich, H., \& Moody, J. 2000. Family Matters: Gender, Networks, and Entrepreneurial Outcomes. Social Forces, 79(2): 523-546.

Rider, C. I., Thompson, P., Kacperczyk, A., \& Tåg, J. 2016. Experience and Entrepreneurship: 


\section{A Career Transition Perspective.}

Rivera, L. A. 2012. Hiring as Cultural Matching: The Case of Elite Professional Service Firms. American Sociological Review, 77(6): 999-1022.

Rivera, L. A. 2013. Homosocial Reproduction. In V. Smith (Ed.), Sociology of Work: An Encyclopedia: $377-379$. Thousand Oaks, CA: SAGE.

Rivera, L. A. 2015. Pedigree: How Elite Students Get Elite Jobs. Princeton, NJ: Princeton University Press.

Roberts, P. W., \& Sterling, A. D. 2012. Network Progeny? Prefounding Social Ties and the Success of New Entrants. Management Science, 58(7): 1292-1304.

Ruef, M., Aldrich, H., \& Carter, N. M. 2003. The Structure of Founding Teams: Homophily, Strong Ties, and Isolation among U.S. Entrepreneurs. American Sociological Review, 68(2): 195-222.

Ruef, M., \& Kwon, S.-W. 2016. Neighborhood Associations and Social Capital. Social Forces, 95(1): 159-190.

Rupasingha, A., Goetz, S. J., \& Freshwater, D. 2006. The Production of Social Capital in US Counties. Journal of Socio-Economics, 35(1): 83-101.

Samila, S., \& Sorenson, O. 2011. Venture Capital, Entrepreneurship, and Economic Growth. Review of Economics and Statistics, 93(1): 338-349.

Samila, S., \& Sorenson, O. 2017. Community and Capital in Entrepreneurship. American Sociological Review, 82(4): 770-795.

Saxenian, A.-L. 1994. Regional Advantage: Culture and Competition in Silicon Valley and Route 128. Cambridge, MA: Harvard University Press.

Shane, S. A. 2008. Fool's Gold? The Truth Behind Angel Investing in America. Oxford, UK: Oxford University Press.

Shane, S., \& Cable, D. 2002. Network Ties, Reputation, and the Financing of New Ventures. Management Science, 48(3): 364-381.

Shane, S., \& Stuart, T. E. 2002. Organizational Endowments and the Performance of University Start-ups. Management Science, 48(1): 154-170.

Simon, H. A. 1957. A Behavioral Model of Rational Choice. Models of Man, Social and Rational: Mathematical Essays on Rational Human Behavior in a Social Setting. New York, NY: Wiley.

Simon, H. A. 1991. Bounded Rationality and Organizational Learning. Organization Science, 2(1): 125-134.

Small, M. L. 2009. Unanticipated Gains: The Origins of Network Inequality in Everyday Life. Chicago, IL: University of Chicago Press.

Smith, A. 1904. An Inquiry into the Nature and Causes of the Wealth of Nations. (E. Cannan, Ed.). Library of Economics and Liberty. 
Smith, T. W., Marsden, P. V., Hout, M., \& Kim, J. 2010. General Social Surveys, 1972- 2010: Cumulative Codebook. Chicago, IL.

Sørensen, J. B. 2007. Closure and Exposure: Mechanisms in the Intergenerational Transmission of Self-employment. Research in the Sociology of Organizations, 25: 83-124.

Sørensen, J. B., \& Sharkey, A. J. 2014. Entrepreneurship as a Mobility Process. American Sociological Review, 79(2): 328-349.

Sorenson, O. 2017. Regional Ecologies of Entrepreneurship. Journal of Economic Geography. https://doi.org/10.1093/jeg/lbx031.

Sorenson, O., \& Audia, P. G. 2000. The Social Structure of Entrepreneurial Activity: Geographic Concentration of Footwear Production in the United States, 1940-1989. American Journal of Sociology, 106(2): 424-462.

Sorenson, O., \& Stuart, T. E. 2001. Syndication Networks and the Spatial Distribution of Venture Capital Investments. American Journal of Sociology, 106(6): 1546-1588.

Sorenson, O., \& Stuart, T. E. 2008a. Bringing the Context Back In: Settings and the Search for Syndicate Partners in Venture Capital Investment Networks. Administrative Science Quarterly, 53(2): 266-294.

Sorenson, O., \& Stuart, T. E. 2008b. Entrepreneurship: A Field of Dreams? Academy of Management Annals, 2(1): 517-543.

Spence, A. M. 1974. Market Signaling: Informational Transfer in Hiring and Related Screening Processes. Cambridge, MA: Harvard University Press.

Spigel, B. 2015. The Relational Organization of Entrepreneurial Ecosystems. Entrepreneurship Theory and Practice, 44(0). https://doi.org/10.1111/etap.12167.

Stedler, H., \& Peters, H. H. 2003. Business Angels in Germany: An Empirical Study. Venture Capital, 5: 269-276.

Stuart, T. E., \& Sorenson, O. 2003. Social Networks and Entrepreneurship. Handbook of Entrepreneurship Research, 28(1): 1-22.

Stuart, T. E., \& Sorenson, O. 2005. Social Networks and Entrepreneurship. Handbook of Entrepreneurship Research: 211-228.

Stuart, T. E., \& Sorenson, O. 2007. Strategic Networks and Entrepreneurial Ventures. Strategic Entrepreneurship Journal, 1(1): 211-227.

Tajfel, H., \& Turner, J. C. 1986. The Social Identity Theory of Intergroup Behavior. In S. Worchel \& W. G. Austin (Eds.), Psychology of Intergroup Relations: 7-24. Nelson-Hall.

Takahashi, N. 2000. The Emergence of Generalized Exchange. American Journal of Sociology, 105(4): 1105-1134.

Ter Wal, A. L. J., Alexy, O., Block, J., \& Sandner, P. G. 2016. The Best of Both Worlds: The Benefits of Open-specialized and Closed-diverse Syndication Networks for New Ventures Success. Administrative Science Quarterly, 61(3): 393-432. 
Thebaud, S. 2015. Business as Plan B: Institutional Foundations of Gender Inequality in Entrepreneurship across 24 Industrialized Countries. Administrative Science Quarterly. https://doi.org/10.1177/0001839215591627.

Tsai, W., \& Ghoshal, S. 1998. Social Capital and Value Creation: The Role of Intrafirm Networks. Academy of Management Journal, 41(4): 464-476.

Tsvetkova, M., \& Macy, M. W. 2014. The Social Contagion of Generosity. PLoS ONE, 9(2). https://doi.org/10.1371/journal.pone.0087275.

Uzzi, B., \& Lancaster, R. 2004. Embeddedness and Price Formation in the Corporate Law Market. American Sociological Review, 69(3): 319-344.

Van Osnabrugge, M., \& Robinson, R. J. 2000. Angel Investing: Matching Startup Funds with Startup Companies--The Guide for Entrepreneurs and Individual Investors. Jossey-Bass.

Walker, G., Kogut, B., \& Shan, W. 1997. Social Capital, Structural Holes and the Formation of an Industry Network. Organization Science, 8(2): 109-125.

Wang, D. J., Pahnke, E. C., \& McDonald, R. 2018. United We Stand? Venture-Capital Syndicates' Joint Co-Investment Experience and Entrepreneurial Exits.

Westlund, H., \& Bolton, R. 2003. Local Social Capital and Entrepreneurship. Small Business Economics, 21(2): 77-113.

Willer, R., Flynn, F. J., \& Zak, S. 2012. Structure, Identity, and Solidarity: A Comparative Field Study of Generalized and Direct Exchange. Administrative Science Quarterly, 57(1): 119155.

Wiltbank, R., \& Boeker, W. 2007. Returns to Angel Investors in Groups. Ewing Marion Kauffman Foundation, Kansas City, MO.

Wiltbank, R., \& Brooks, W. T. 2016. Tracking Angel Returns. Ewing Marion Kauffman Foundation, Kansas City, MO.

Yamagishi, T., \& Cook, K. S. 1993. Generalized Exchange and Social Dilemmas. Social Psychology Quarterly, 56(4): 235.

Yamagishi, T., Nobuhito, J., \& Kiyonari, T. 1999. Bounded Generalized Reciprocity: Ingroup Boasting and Ingroup Favoritism. Advances in Group Processes, 16: 161-197.

Yenkey, C. B. 2017. Fraud and Market Participation: Social Relations as a Moderator of Organizational Misconduct. Administrative Science Quarterly.

https://doi.org/10.1177/0001839217694359. 